\title{
Predictive models of tumor angiogenesis
}

Citation for published version (APA):

Barendsz-Janson, A. F. (1998). Predictive models of tumor angiogenesis. [Doctoral Thesis, Maastricht University]. Universiteit Maastricht. https://doi.org/10.26481/dis.19981113ab

Document status and date:

Published: 01/01/1998

DOI:

10.26481/dis.19981113ab

Document Version:

Publisher's PDF, also known as Version of record

\section{Please check the document version of this publication:}

- A submitted manuscript is the version of the article upon submission and before peer-review. There can be important differences between the submitted version and the official published version of record.

People interested in the research are advised to contact the author for the final version of the publication, or visit the DOI to the publisher's website.

- The final author version and the galley proof are versions of the publication after peer review.

- The final published version features the final layout of the paper including the volume, issue and page numbers.

Link to publication

\footnotetext{
General rights rights.

- You may freely distribute the URL identifying the publication in the public portal. please follow below link for the End User Agreement:

www.umlib.nl/taverne-license

Take down policy

If you believe that this document breaches copyright please contact us at:

repository@maastrichtuniversity.nl

providing details and we will investigate your claim.
}

Copyright and moral rights for the publications made accessible in the public portal are retained by the authors and/or other copyright owners and it is a condition of accessing publications that users recognise and abide by the legal requirements associated with these

- Users may download and print one copy of any publication from the public portal for the purpose of private study or research.

- You may not further distribute the material or use it for any profit-making activity or commercial gain

If the publication is distributed under the terms of Article $25 \mathrm{fa}$ of the Dutch Copyright Act, indicated by the "Taverne" license above, 
Predictive models of tumor angiogenesis 
- Barendsz-Janson, Anmemarie, Ferdinanda ISBN 90-9011934-5

Printing of this thesis was made possible by Dr Ir JHJ van der Laar Foundation and Dr Saal van Zwanenberg Foundation 


\section{Predictive models of tumor angiogenesis}

\section{PROEFSCHRIFT}

ter verkrijging van de graad van doctor aan de Universiteit Maastricht, op gezag van de Rector Magnificus, Prof dr AC Nieuwenhuijzen Kruseman, volgens het besluit van het College van Decanen, in het openbaar te verdedigen op vrijdag 13 november 1998 om 12.00 uur

door

A I Barendsz-Janson

geboren op 15-01-1970 te Sittard 


\section{Promotores}

Prof dr HFP Hillen

Prof dr MCE van Dam-Mieras (Open Universiteit Heerlen)

Co-promotor

Dr AW Griffioen

\section{Beoordelingscommissie}

Prof dr J-W Arends (voorzitter)

Prof dr CA Bruggeman

Prof dr $\mathbf{J}$ de Haan

Prof dr VWM van Hinsbergh (Vrije Universiteit Amsterdam)

Prof dr AT van Oosterom (Katholieke Universiteit Leuven) 
Aan: Diederick en mijn ouders 



\section{Contents}

\section{Abbreviations 8 \\ Chapter 1: General introduction 9}

Chapter 2: Introduction to the experimental work 35

Chapter 3: Cellular arrangement of human breast cancer cell lines determines hemostatic parameters $\mathbf{4 1}$

Chapter 4: In vitro tumor angiogenesis assays: plasminogen lysine binding site 1 inhibits in vitro tumor induced angiogenesis $\mathbf{5 7}$

Chapter 5: In vitro effects of anti-tumor drugs on angiogenesis 71

Chapter 6: Apoptosis induction and anti-proliferative effects of suramin and its analog suradista 87

Chapter 7: Angiogenic potential of malignant and non-malignant human breast tissues in an in vivo angiogenesis model $\mathbf{1 0 1}$

Chapter 8: General discussion 115

Samenvatting 129

Dankwoord 135

Curriculum vitae 139 


\section{Abbreviations}

$\alpha \mathrm{MEM}$ alpha minimum essential medium

ATIII antithrombin III

BMEC bovine microvascular endothelial cells

CAM chorioallantoic membrane

$\mathrm{CP} \quad$ cancer procoagulant

DCS donor calf serum

DMEM Dulbecco's modified Eagle's medium

EC endothelial cells

ECGF endothelial cell growth factor

ECM extracellular matrix

EGF endothelial growth factor

ELISA enzyme linked immunosorbent assay

ER estrogen receptor

FBS foetal bovine serum

FGF fibroblast growth factor

FGFR fibroblast growth factor receptor

HBGF heparin binding growth factor

HUVEC human umbilical vein endothelial cells

ICAM intercellular adhesion molecule

IIFN interferon

IGF insulin like growth factor

KGF keratinocyte growth factor

LBS-I lysine binding site 1

LPS lipopolysaccharide

MVEC microvascular endothelial cells

PAI plasminogen activator inhibitor

PBS phosphate buffered saline

PDGF platelet derived growth factor

PECAM platelet endothelial cell adhesion molecule

PF -4 platelet factor -4

PR progesterone receptor

TAF tumor angiogenic factor

TGF transforming growth factor

TF tissue factor

TIMP tissue inhibitor of metalloproteinase

TNF tumor necrosis factor

tPA tissue type plasminogen activator

TSP-1 thrombospondin 1

uPA urokinase type plasminogen activator

VCAM vascular cell adhesion molecule

VEGF vascular endothelial growth factor

VPF vascular permeability factor

VWF von Willebrand factor 


\section{Chapter 1}

\section{General introduction}

AF Barendsz-Janson

Partly published in J Lab Clin Med (in press) 


\section{Introduction}

Angiogenesis is the formation of new vessels from preexisting vessels by cellular outgrowth. This process occurs almost from the onset of fertilization. Vessels are important for the transport of oxygen and nutrients to tissues and the removal of waste products from the tissues. Upon implantation of the embryo a vascular network between the embryo and placenta is necessary to supply the developing fetus with chemical components and energy to allow for its growth. A variety of physiological events in the adult also involves angiogenesis. These include the development of the corpus luteum and the endometrium during implantation of the fertilized oocyte, the menstrual cycle, inflammation, wound repair and delayed iype hypersensitivity reactions. Under pathologic conditions, angiogenesis is observed in chronic inflammatory responses, keloid formation and diabetic retinopathies ${ }^{1-5}$. Evidence that tumor growth and tumor metastasis are dependent of the formation of new vessels has drawn special attention to the pathological and clinical significance of tumor angiogenesis.

\section{(Tumor) angiogenesis history}

In the last century, Virchow ${ }^{6}$ was among the first to point at the high vascularity associated with tumors and its disorganized nature. The origin of the vessels was uncertain. Could the tumor cells themselves transform into endothelial-like cells which are lining these vessel or have normal cells been derived from the neighbouring benign tissues? Goldmann ${ }^{7}$ suggested that in tumors the trigger which gives rise to the prolliferation of blood vessels emanates from the invading cell. ${ }^{6.9}$. It was proposed that the ability to attract the new blood vessels from the host was a characteristic feature of tumor cells.

Many different model systems have been developed to study angiogenesis ${ }^{10-18}$. As early as 1939 , Ide et al. ${ }^{17}$ studied vascularization within a transparent chamber implanted into the rabbit ear, Algire ${ }^{18}$ adapted this technique to the mouse and Greenblatt and Shubik ${ }^{13}$ implanted the chamber into the cheek pouch of the hamster. In 1974 the group of Folkman started to employ angiogenesis in the cornea of a rabbit as a model system. They inserted tumor implants at definite distances from the corneal edge and its normal vessels and examined the newly formed vessels ${ }^{19}$. Leighton developed a model based on opening the shell of a chicken embryo and manipulating the chorioallantoic membrane to observe the growth of vessels of the developing embryo ${ }^{20}$. Sutherland developed a threedimensional in vitro model using tumor spheroids to induce sprouting of endothelial cells $^{21-2 \theta}$ while others focussed on the use of sustained-release polymer implants for 
this purpose ${ }^{27}$. For these in vitro assays many different endothelial cells were used, e.g. human umbilical vein endothelial cells, microvascular endothelial cells from the foreskin, bovine adrenal cortex endothelial cells and tumor-derived endothelial cells $^{28.33}$. Especially in vitro assays using cultured microvascular endothelial cells growing either in a two- or three dimensional system contributed to our understanding of the molecular and cellular mechanisms relevant in the angiogenic process $s^{34,39}$. Much work is also done on "ex vivo" determination of microvessel density in archival tumor blocks using staining techniques specific for endothelial cells, as microvessel density has been described to be a prognostic marker for metastasis in a wariety of tumors ${ }^{36,37}$.

The hypothesis that "Tumor growth is angiogenesis dependent" was first proposed in $1971^{38}$. This hypothesis rests in part on the following evidence:

- tumors grown in organs where blood vessels do not proliferate are limited to 1-2 $\mathrm{mm}^{3}$ but expanded rapidly to $1-2 \mathrm{~cm}^{3}$ after vascularization on transplantation to mice $^{15,39}$.

- tumors suspended in aqueous fluid remain viable, avascular and limited in size $\left(<1 \mathrm{~mm}^{3}\right)$. Once they are implanted, they induce neovascularization and grow rapidly, reaching 16,000 times their original volume within two weeks ${ }^{40}$.

vascular casts of metastases to the rabbit liver show that these tumors are avascular up to $1 \mathrm{~mm}$ in diameter, beyond that size, the tumors are vascularized $^{41}$.

- after subcutaneous injection of tumor cells into mice, tumors become vascularized at about $0.4 \mathrm{~mm}^{3}$. With increasing tumor size, the blood vessels occupied approximately $1.5 \%$ of the tumor volume ${ }^{42}$.

An avascular tumor can become dormant and can persist in that stage for a rather long period of time during which there is no growth, no invasion and no formation of metastases. The tumor can stay dormant or can reassume growth and will in the latter case rapidly induce vessel formation to grow and expand ${ }^{9,15,40}$.

The conclusion from these arguments that tumor expansion beyond the size of approximately $2 \mathrm{~mm}^{3}$ is angiogensis dependent is generally accepted now. Besides tumor growth angiogenesis also plays a role in the formation and expansion of tumor metastases. The process of metastasis formation consists of linked sequential steps. Only a small proportion of cancer cells released from a primary tumor will succesfully form distant metastases. Tumor cells must gain access to the vasculature, survive the circulation, escape the immune surveillance, escape from the vasculature and grow into a target organ. To expand it has to induce angiogenesis again.

More than a century ago Paget ${ }^{43}$ proposed that the location where the metastases are formed was due to specific affinity of certain tumor cells (the "seed") for the (micro) environment provided by certain organs (the "soil"). Forty years later, 
James Ewing 44 challenged the theory that had become known as Paget's "seed and soil" hypothesis. Ewing postulated that the specific location could be attributed entirely to the routes of blood flow that carried tumor cells away from the primary site. The first organ encountered by tumor cells would be the site of greatest tumor cell arrest. The hypothesis of Ewing has become known as the "mechanical" theory of metastatic spread. Probably the truth is in between and both factors related to the "affinity" of a tumor cell for a micro environment and factors related to transport from the primary tumor to the site of metastasis formation are involved, but that the wasculature plays an important role is clear ${ }^{7.45,46}$.

\section{Tumor ressel characteristics}

New capillaries arise from pre-existing capillaries or venules, never from arteries, arterioles or veins. The development of new blood vessels is a rather complicated and not well understood process in which a variety of factors are involved. Blood cells, cells of the vascular wall, matrix components, cytokines and adhesive receptors all contribute to the process. The ultimate result of the process must be a functioning extension of the vascular system which adequately fulfils its physiologic function.

The vascullar system of malignant tumors differs from that of normal tissues in many aspects. These include the vascular morphology and branching patterns which varies even from region to region within a tumor and among tumors. Blood vessels in tumors periodically are able to change their direction of flow and their function in the circulation ${ }^{47}$. They have no innervation like normal vessels and are more leaky. When tumor vessels are compared with vessels formed after tissue traumata some clear distinctions are evident. Endothelial cells in a tumor contain more intraendothelial organelles, are more flattened and lack a basal lamina. Furthermore, tumor cells are also part of the endothelial lining ${ }^{48.50}$. The most important difference however is the increased permeability of the tumor vessels, for which reason they are called "leaky vessels". This leakiness is caused by several factors. In normal tissues, the blood vessels are surrounded by a basement membrane, which may be damaged or missing in tumors. In addition, the anatomically well-defined functioning lymphatic vessels present in normal tissues may be absent in solid tumors. Because of the absence of the lymphatic vessels, the hydrostatic pressure in the tumor interstitium is very high ${ }^{31.54}$.

The endothelial cells rest on the basal membrane that anchors them to the blood vessel wall and contacts the underlying pericytes, smooth muscle cells and mesangial cells. The basal membrane and the extracellular matrix of the vessels contains collagen, elastin, microfibrils, laminin, proteoglycans, glycosaminoglycans, mucopolysaccharides and some fibronectin and thrombospondin. It plays an important rolle in the responsiveness of endothelial cells towards stimuli ${ }^{1.59}$. In the strongly reduced amount of basal membrane material of tumor blood vessels the 
level of hyaluronic acid in the glycosaminoglycans is increased and the proteoglycans are less sulphated. These factors contribute to the increased permeability of the tumor vessels $s^{5.56}$.

A number of stages in angiogenesis, including endothelial cell invasion and capillary lumen formation, are believed to be dependent on tightly controlled proteolytic degradation of the extracellular matrix. An appropriate balance between proteases and protease inhibitors in these processes is very important. Lumen formation is inhibited in the presence of an excess of protease inhibitors but when there is a lack of inhibitors, there is an excessive proteolysis which is incompatible with normal capillary morphogenesis ${ }^{29}$. Insufficient vascularization of a tumor can have negative and positive effects. Some negative effects are radioresistance due to oxygen deficiency, limited penetration of therapeutic agents, growth regulating hormones, immunoglobulins and macrophages. The release of cell debris and catabolic products from the tumor causes paraneoplastic effects. Some positive effects are growth retardation due to deficiency of oxygen, glucose, amino acids and other metabolites, as well as growth retardation due to accumulation of catabolic products (low $\mathrm{pH}$, high osmolality, high ion strength or specific toxicity) ${ }^{26}$.

\section{The angiogenic cascade}

The formation of new vessels is a multistep process (figure 1.l) (reviewed in Lichtenbeld et al ${ }^{57}$ ). Upon induction by a tumor, endothelial cells in neighbouring normal capillaries which do not possess a muscular sheath are activated to secrete proteases and collagenases. The basal membrane is dissolved by the enzymes and the endothelial cells start to migrate from the vascular wall into the extracellular matrix in the direction of the angiogenic stimulus. Small sprouts are thus formed which grow toward the tumor by migration. Very often one elongated (fibroblastlike), spindle-shaped endothelial cell is at the front. During these early events, the endothelial cells within the sprouts are required only from the "store" in the parental vessel. Replication of endothelial cells occurs behind the leading front of the migrating sprouts. Migration and replication are not necessarily linked together but proliferation is necessary for a successful completion of angiogenesis. Lumina develop in the primary solid cords of endothelial cells by the formation of intracellular vacuoles and intracellular gaps and mitosis continues. From the primary loops, new buds and sprouts emerge. The tip of the hollow sprout, which may be filled with blood, has been observed to be leaky. It spills out blood at the beginning of the angiogenic process which results in tibrin formation. Neighbouring sprouts fuse to form loops (anastomoses), whereafter the first signs of circulation can be recognized. Functional vessels are transiently established by the appearance of pericytes and formation of a basal membrane by the endothelial 
cells. With increasing ingrowth into the tumor, the first vessel which penetrates the tumor starts to collapse and induces the formation of new vessels in the neighbourhood. These new vessels are again rather leaky and fragile. During the maturation of newly formed blood vessels, endothelial cells lay down a basal membrane on the new vessels to reinforce them and to change their permeability. Persistent remodelling of the vascular system within the tumor starts as soon as the first vessels are no longer sufficient to meet the nutritional requirement of the expanding tumor ${ }^{1,9,57}$.
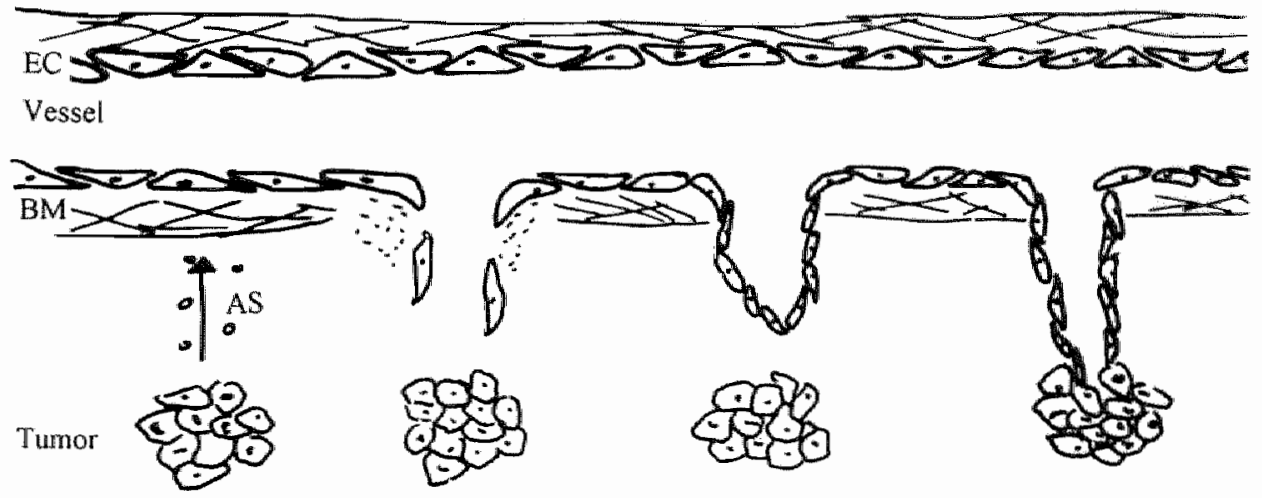

ACTIVATION MIGRATION PROLIFERATION

Figure 1.1

The angiogenic process. Tumor cells activate by angiogenesis stimulators (AS) endothelial cells (EC) in nearby host vessels to synthesize proteolytic enzymes (activation). Digestion of the basement membrane (BM) and migration of endothelial cells follow. The budding sprout proliferates" to expand and form at lumen necessary for the establishment of mature and elongated vessulw.

\section{Endothelial cell adhesion molecules}

In the early steps of angiogenesis and host-tumor interaction not only proteolytic enzymes but also adhesion molecules play a critical role. Adhesion molecules are involved in the interaction of cells with their micro environment. They are classified in five families: selectins, the immunoglobulin supergene family, integrins, cadherins and other cell adhesive proteins (reviewed by Griffioen ${ }^{58}$ and Brooks ${ }^{59}$ ). Adhesion molecules play a crucial role in, for instance, the extravasation of immune cells which is a multistep process. First there is a rather loose contact between the blood cells and the vasculature and the cells are rolling on the vasculature. Subsequently the leukocytes become activated and this results in tight adhesion to the vascular wal]. The last step is diapedesis of leukocytes through the 
vessel wall, after which tumors or other undesired processes can be destroyed by the immune system (figure 1.2). When one of the adhesion molecules is absent, the extravasation process is disturbed.

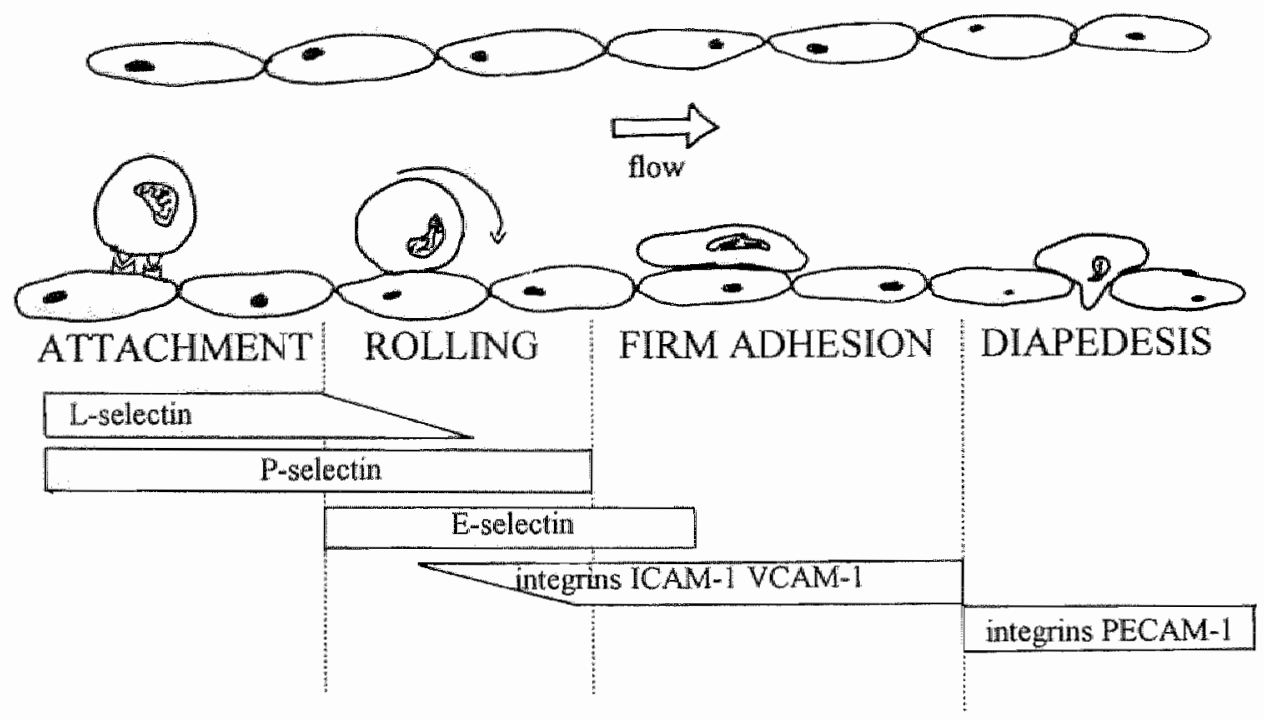

Figure 11.2 The interaction of leukocytes with the vascullar wall. The expression pattern of the most importani adhesion molecules during this process. (ICAM= intercellular adhesion molecule; $\mathrm{VCAM}=$ vascular adhesion molecule; PECAM = platelet endothelial cell adhesion molecule $)^{60}$.

It will be evident that regulation of extravasation and the organization of a defense reaction at the site of tumor growth is of utmost importance in the host-tumor interaction. The expression of endothelial adhesion molecules is orchestrated by the local conditions. For example, ICAM-2 is expressed at high levels on resting endothelial cells, ICAM- 1 and VCAM-1 are variably expressed, but are upregulated after stimulation with cytokines (such as tumor necrosis factor- $\alpha$, $\gamma$-interferon or interleukin-1) which are expressed during lymphocyte activation or an inflammatory response. The expression can also be influenced by the addition of angiogenic factors like basic fibroblast growth factor (bFGF) and vascular endothelial growth factor (VEGF). It has been described that on tumor-associated endothelial cells ICAM-I and ICAM-2 expression is decreased which would obviously be protective to the tumor ${ }^{33,61,62}$. 
Two other examples of adhesion molecules are CD34 and CD44. The function of CD34 on endothelial cells is not known thought it has been demonstrated to function as a ligand for L-selectin resulting in leukocyte attachments. In tumor associated vessels the expression of CD34 is down-regulated. Both bFGF and VEGF induced an accelerated down-regulation of CD34 ${ }^{6.3}$. Also this may serve as a tumor protecting mechanism by impairing the development of an efficient leukocyte infiltration in tumors.

CD44 is a cell adhesion molecule with proposed functions in extracellular matrix binding, metastasis formation and leukocyte homing and activation. It has been reported that CD44 expression in the tumor vasculature is augmented as compared to normal vessels. VEGF and bFGF are both able to upregulate this expression. For that reason CD44 could be a target for therapy with immunotoxins ${ }^{64}$.

An example of an integrin involved in angiogenesis is $\alpha_{k} \beta_{3}$, the receptor for vitronectin. Integrins are transmembrane extracellular matrix (ECM) receptors which can bind to a number of ECM components such as fibronectin, collagen and vitronectin. Changes in the ECM composition due to either altered secretion of ECM components and/or extensive proteolytic remodeling can modulate the cellECM interactions and in that way the angiogenic cascade. The ligation of $\alpha_{4} \beta_{3}$ provides a critical survival signal necessary for growth and maturation of blood vessels during the angiogenic cascade. It is demonstrated that antagonists of $\alpha_{4} \beta_{3}$ block angiogenesis induced by bFGF, TNF- $\alpha$ (tumor necrosis factor- $\alpha$ ) and a variety of solid human tumors by selectively promoting apoptosis of vascular cells $\mathrm{s}^{65,66}$.

\section{Coagulation and (tumor-)angiogenesis}

Due to the changed vessel characteristics in patients with cancer, compared to healthy individuals, the coagulation is often disturbed. Coagulation, platelet aggregation and fibrin formation are thought to play an important role in the growth and dissemination of cancer cells and in tumor angiogenesis. Defects of hemostasis in patients with cancer have long been recognized; Trousseau ${ }^{6 \%}$, in 1865, was the first to note this association. The first described abnormality of hemostasis in malignancy was that of hypercoagulability and thrombosis. The first large survey of blood changes in cancer patients showed decreased bleeding times in over $60 \%$ of patients studied. Many patients had elevated clotting factors. Also increased fibrinogen and platelet catabolism were found in many patients with disseminated malignancy ${ }^{68}$. In 1970 Soong $^{69}$ found marked disturbances in the coagulation and fibrinolytic system in 100 unselected patients with disseminated malignancies. Apparently malignant tumors activate the coagulation and fibrinolytic system ${ }^{69}$.

In many solid tumors, locally increased microvascular permeability results in 
extravasation of fibrinogen and subsequently extravascular coagulation results in the formation of a fibrin gel, with concomitant covalent cross-linking of fibrin by factor $\mathrm{XIII}_{a}$. Over time the fibrin gel becomes "organized"; i.e. it is gradually replaced, first by gramulation tissue and later by more mature collagenous connective tissue that is designated "desmoplasia" in tumors". Fibrin formation can also strongly modify the behavior of endothelial cells as the orientation of the fibrous elements of the extracellular matrix influences the direction of outgrowth of vascular sprouts. In this way fibrin provides a provisional matrix which facilitates the development of a vascular network and thus contributes to the supply of the tumor with building blocks and energy $9.68,69,71,74$.

In addition to the normal hemostatic mechanism also cancer procoagulant (CP), a procoagulant substance from malignant tissues, may play a role in fibrin deposition in malignant tumors and in vascular thrombosis observed in cancer patients. $C P$ is a vitamin $\mathrm{K}$ dependent cysteine protease with direct factor $\mathrm{X}$ activating activity. Falanga ${ }^{72}$ suggests that $\mathrm{CP}$ may be a coagulation factor unique to malignant tissue. It can activate factor $X$ in the absence of factor VII, in contrast to tissue factor which is the most potent trigger of blood coagulation under normal conditions ${ }^{72,75,76}$. At the moment $\mathrm{CP}$ is one of the topics extensively studied in cancer related coagulation research.

\section{Angiogenic factors}

Tumors are capable to produce mitogenic and/or angiogenic factors that induce the sprout formation in host vessels by endothelial cell activation. Many factors are known (reviewed by Battegay ${ }^{77}$ and Baillie ${ }^{78}$ ). Only a selection is described in this part. Vascular endothelial growth factor is such a factor which may also contribute to the leakiness of the newily formed vessels ${ }^{53,79}$.

The issue of specific factors promoting the development of new blood vessels by tumor cells was clearly evidenced by Greenblatt and Shubik ${ }^{13}$. Angiogenic factors must provoke three main activities of endothelial cells: (1) the production and secretion of enzymes able to digest the ECM, (2) the initiation of migration, and (3) proliferation (DNA synthesis and mitosis). Factors which can stimulate tumor angiogenesis are called tumor angiogenic factors (TAF) ${ }^{45,80}$. A direct angiogenic factor is capable of inducing endothelium proliferation and/or migration in vivo and stimulate endothelial cells in vitro. When the in vitro action fails, or is inhibited, the angiogenic factor is considered to be indirect assuming that it mobilizes other direct factors or cells in wivo. Some examples of direct factors are FGF, VEGF and PDGF (platelet derived endothelium growth factor). Indirect factors are transforming growth factor, TNF- $\alpha$ and angiogenin ${ }^{81}$. The first growth factors described were bFGF isolated from bovine pituitary and brain ${ }^{82,83}$ and endothelial cell growth factor (ECGF) isolated from the hypothalamus ${ }^{* 4}$. 
The Heparin Binding Growth Factors (HBGF), also called fibroblast growh factors are the most extensively studied peptides in the context of angiogenesis ${ }^{30,55-8}$ ? Gospodarowicz ${ }^{82,83}$ identified a polypeptide mitogen from pituitary and called it FGF. Several other tissue extracts with similar biological activities were described during the following period. Many have subsequently turned out to be FGF". Until now there are 9 structurally related members of the FGF family. The first discovered members were acidic-FGF and basic-FGF also called HBGF-1/ ECGF/FGF-1 and HBGF-2/FGF-2 respectively. The other known members of the FGF family are Int-2/FGF-3 ${ }^{89}$, hist-1/FGF-4 $4^{90,91}$, FGF-5 ${ }^{92}$, hst-2/FGF-6 ${ }^{93}$, FGF-7/ KGF (keratinocyte growth factor) ${ }^{94}$, FGF- $8^{95}$ and FGF-9 96 . They share $30-50 \%$ amino acid identity. Despite their nomenclature, some FGFs such as FGF-7 in fact lack a fibroblast stimulating activity.

The FGFs induce their effects in responding cells by binding to cell surface receptor tyrosine kinases of subclass IV thereby modulating gene expression resulting in cell proliferation and differentiation. All five known FGF receptors (FGFR-1 to FGFR-5) have three immunoglobulin-like domains in their extracellular part, their cytoplasmic tyrosine-kinase domains are interrupted by short hydrophilic insertion sequences ${ }^{97,98}$.

About aFGF and bFGF much more is known. They are single chain polypeptides which share $55 \%$ sequence homology. The FGF genes demonstrate a similar genomic organization. They consist of three exons separated by two introns of variable length. aFGF is an anionic mitogen with a molecullar weight of $15-17 \mathrm{kD}$; bFGF is a cationic mitogen with a molecular weight of about $18 \mathrm{kD}$. Both FGFs are present in many tissues including brain, kidney and adrenal and are potent stimulators of DNA synthesis and cellular division. FGF is able to stimulate endothelial cell migration, division, release of proteolytic enzymes (such as collagenases and plasminogen activators) and capillary tube formation in vitro. It is mitogenic and chemotactic for cultured endothelial cell $s^{86.99}$.

The role of bFGF in growth and metastatic behavior of tumors is at least twotold. Directly, it stimulates proliferation. Indirectly it stimulates angiogenesis which is necessary for tumor expansion ${ }^{1020} 102$. In primary and metastatic human melanomas it has been demonstrated that inhibition of bFGF- and FGFR-1-mediated signalling blocks melanoma angiogenesis leading to extensive tumor necrosis and growth arrest or regression of the melanomas ${ }^{103}$. Another indirect effect is that bFGF down regulates adhesion molecule expression (such as ICAM-1 and VCAM-1) and suppresses the lymphocyte emigration. In that way an insufficient helper function in local immune respons is established ${ }^{62}$.

Vascular endothelial growth factor also known as vascular permeability factor or vasculotropin is an endothelial cell-specific mitogen which is angiogenic in vivo. It 
is purffied from conditioned medium from bovine pituitary folliculo stellate cells and from tumor cells $s^{35,104}$. Four different homodimeric species of VEGF have been identified until now, each monomer having $121,165,189$ or 206 amino acids respectively. $\mathrm{VEGF}_{121}$ and $\mathrm{VEGF}_{1 \mathrm{~s}}$ are diffusible after secretion; VEGF VEGF $_{2 n \text { f }}$ are secreted but are bound to heparin-containing proteoglycars in the cell surface or basement membrane ${ }^{105}$. VEGF and their receptors colocalize with sites of neovascularization ${ }^{35,106}$.

VEGF, a member of the PDGF family, is a dimeric glycoprotein of $23 \mathrm{kD}$ subunits $^{105,106}$. It is a multifunctional cytokine which induces vessel permeability and modifies the extracellular matrix by promoting plasma protein extravasation with resulting fibrin deposition. VEGF enhances the expression of plasminogen activators and collagenases in endothelial cells ${ }^{35.107}$. It is also able to directly stimulate growth of vascular endothelial cells and protect these cells against cell death by inhibiting apoptosis in vascular endothelial cells ${ }^{53,108,109}$. VEGF is, just like FGF, a heparin binding growth factor ${ }^{i 06}$. VEGF is distinguished from other heparin-binding angiogenic factors by several features. First, because its $\mathrm{NH}_{2}$ terminus is preceded by a typical signal sequence VEGF can be secreted by intact cells. Second, its binding sites, shown recently to include the tyrosine kinase receptors flt, flk-1 and $K D R$, are present in endothelial cells, quiescent as well as proliferating, but not in other cell types ${ }^{105}$. When added simultaneously, VEGF and bFGF induced an in vitro angiogenic response which was far greater than additive and which occurred with greater rapidity than the response to either cytokine alone ${ }^{35}$. It is a factor solely acting on endothelial cells, widely expressed in tumors but not in normal tissues. If VEGF is inhibited by a specific antibody, microvascular density is reduced and there is a dramatic inhibition of tumor growth ${ }^{108,110,111}$.

VEGF acts directly on vascular endothelial cells by binding to the receptor. Several effects follow the interaction of VEGF with the receptor. The earliest effect to be detected is an increase up to fourfold of cyloplasmic calcium. In addition to increasing intracellular calcium, VEGF causes endothelial cells to assume an elongated shape and stimulates their replicaton ${ }^{53.112}$. The expression of VEGF can be upregulated by hypoxia and suppressed by overexpression of the tumor suppressor gene p53, whereas mutant p53 has no effect. Hypoxia activates Src, which on his turn induces VEGF'13-15. Many effects of VEGF are caused by stimulating the signal transduction pathways. It is able to upregulate nitric oxide (NO) in endothelial cells that are dysfunctional. VEGF is in turn upregulated in the absence of anatomically or functionally intact endothelium. Restoration of the endothelial cell integrity leads to VEGF downregulation by NO. NO inhibits the protein kinase $\mathrm{C}$ induced binding of the transcription factor activator protein-1 to the VEGF promoter ${ }^{116}$. VEGF is also able to phosphorylate focal adhesion associated proteins as p $125^{\mathrm{FAK}}$ and paxillin and in that way stimulate migration and actin stress fiber formation in confluent human endothelial cells ${ }^{17}$. VEGF can also 
act directly on endothelial cells by way of specific receptors to activate phospholipase $\mathrm{C}$ and induce intracellular calcium transientis ${ }^{5.3}$.

Angiogenin, a polypeptide of $14.4 \mathrm{kD}$ first isolated from the conditioned medium of a human adenocarcinoma cell line, is a potent stimulator of angiogenesis just like HBGF. It differs from the latter in the fact that angiogenin lacks sequence homology to either aFGF or bFGF, and does not bind to heparin. It is secreted by cells in culture and contains a signal peptide of 22 to 24 amino acids. Although angiogenin stimulates angiogenesis in vivo, it does not appear to be a mitogen for vascular endothelial cells in vitro. This suggests that angiogenin elicits its activity via other cell types ${ }^{79,111,118}$.

Transforming growth factors (TGFs) are polypeptides that when originally isolated from viral-transformed rodent cells were found to alter the phenotype of some normal cells to transformed cells. There are two structurally distinct TGFs purified, TGF- $\alpha$ and TGF- $\beta$. TGF- $\alpha$, synthesized by transformed cells, has $35 \%$ homology to epidermal growth factor (EGF). Both bind to the same receptor and stimulate microvascular endothelial cell proliferation. Significantly higher concentrations of TGF- $\alpha$ were required to induce angiogenesis in the hamster cheek pouch than were necessary to $\mathrm{HBGF}^{119}$. TGF- $\beta$, with a molecular weight of $25 \mathrm{kD}$ is found in tumors as well as in normal cells including kidney, placenta and blood platelets. It inhibits proliferation of vascular endothelial cells in vitro, but stimulates new capillary formation in vivo. TGF- $\beta$ promotes the organization of single endothelial cells embedded in a three-dimensional collagen gel into tube like structures but it has also been demonstrated that it inhibits endothelial cell invasion and tube formation. This inhibition is caused by the stimulating effect of $\mathrm{TGF}_{-} \beta$ on the production of plasminogen activator inhibitor-1 (PAI- $\|$ ) by the endothelial cells. A biphasic nature of effect of TGF- $\beta$, which is depending on the concentration, can either inhibit or potentiate in vitro angiogenesis. TGF- $\beta$ can stimulate or inhibit growth of certain nonmendothelial cells depending on whether the cells are anchored or not and on the presence or absence of EGF. There is an autocrine inhibition of tumor cells by TGF- $\beta$ but also a paracrine stimulation. By these results it has been suggested that TGF- $\beta$ acts as a bifunctional regulator of cell growth in vitro ${ }^{29,35,79,111,120 \cdot 123 .}$

Tumor necrosis factor- $\alpha$, a proinflammatory pleiotropic and heparin-binding cytokine secreted by monocytes and macrophages, has been implicated in the intratumoral regulation of angiogenesis. Its activity in tumors is twofold; it stimulates tumor development by promoting vessel growth and it participates in tumor destruction by direct cytotoxicity ${ }^{124.125}$. At high dose, TNF- $\alpha$ exhibits angiogenesis inhibiting activity whereas at low dose it stimulates angiogenesis. 
Because local tissue concentration of TNF- $\alpha$ is seldom high enough to be antiangiogenic, it is most likely that TNF- $\alpha$ stimulates tumor angiogenesis in situ $^{126}$. TNF $-\alpha$ is able to stimulate plasminogen activator production by endothelial cells which induces proteolysis of the extracellular matrix and the release of matrix bound angiogenic factors. The production of several matrix metalloproteinases by human endothelial cells is also induced ${ }^{125,127}$. Another effect of TNF- $\alpha$ is the upregulation of adhesion moleculles such as E-selectin and P-selectin, ICAM-1 and VCAM-1. The cellular miRNA levels of II-8, VEGF, bFGF and their receptors are increased in human microvascular endothelial cells after TNF- $\alpha$ treatment whereas transcription factors $\mathrm{Spl}, \mathrm{NF}-\kappa \mathrm{B}$ and $\mathrm{AP}-\mathrm{l}$ are involved in the TNF- $\alpha$ induced angiogenesis also ${ }^{128.129}$. On the other hand, $\mathrm{TNF}_{-\alpha}$ is, for example, able to inhibit angiogenesis by the induction of apoptosis ${ }^{109}$.

\section{Inhibitors of angiogenesis}

It will be evident from the foregoing that imposed inhibition of angiogenesis may be very important for tumor treatment. We must bear in mind, however, that due to the specific characteristics of the tumor vasculature delivery of drugs to the tumor vasculature may be counteracted by the high interstitial pressure in the tumor. For inhibitors with a high molecular weight delivery may even be more difficult. In the search for anti-angiogenic compounds two methodologies for measuring the effect have been used.

- the end result of the total angiogenic process is measured (e.g. bFGF-induced angiogenesis on the chorioallantoic membrane of the chick).

- a part of the angiogenic process is influenced by blocking one of the steps of this process (e.g. inhibition of protease activity or of endothelial migration or proliferation).

Some agents are already described in their role in inhibiting one or more of the steps involved in the angiogenic process (reviewed by Auerbach ${ }^{30}$ and Baillie ${ }^{78}$ ). Only a selection, important for this thesis, is presented here (table 1.1).

The migration of cells can be affected in a number of ways. An agent can directly act on endothelial cells, it can interfere with migration-inducing factors or it may alter the ECM so that movement is no longer possible. 
Table 1.1 Angiogenesis inhibitors.

\begin{tabular}{llc}
\hline Inhibitor & Mode of action & Reference \\
\hline $\begin{array}{l}\text { Physiological } \\
\text { angiostatin/endostatin }\end{array}$ & endogenous inhibitor EC proliferation & 130,131 \\
IFN- $\alpha$ & downregulation of bFGF mRNA & 132 \\
PF-4 & binding and neutralizing heparin \\
Pharmacological & binding of growth factors & 109,110 \\
suramin & inhibits endothelial cell proliferation & $133-137$ \\
tamoxifen & inhibits metalloproteinases & $141-143$ \\
batimastat/marimastat & promotes mircotubule assembly & 129 \\
taxol & & \\
\hline
\end{tabular}

Inhibitors of proteases (for example PAI) and tissue inhibitors of metalloproteinases (e.g. TIMP) are anti-angiogenic because they prevent the breakdown of matrix proteins and, thus, maintain the integrity of endothelium and surrounding matrix. TIMP-2 may not only affect basement membrane breakdown, but act directlly on endothelial cell proliferation. TNF- $\alpha$ has been shown to increase TIMP production at low concentrations, but to reduce TIMP activity at higher concentrations. TNF- $\alpha$ can both inhibit and promote angiogenesis ${ }^{124,130}$. Batimastat (BB94) and marimastat (BB2516) are synthetic peptides which were designed to inhibit metalloproteinase activity. They bind to a zinc-binding region of the metalloproteinase and inhibit the enzyme activity. They mimic the substrate for matrix metalloproteinases, so the peptides work by competitive, potent but reversible inhibition. Without matrix degradation, the endothelial cells are not able to form outgrowing sprouts ${ }^{\text {142-144 }}$. Taxol is an example of a direct acting agent. It limits the cytoskeleton reorganization of the endothelial cells ${ }^{30}$. It is also able to activate local release of an apoptosis-inducing cytokine ${ }^{\text {tas }}$. Another direct acting agent is interferon- $\alpha$ (IFN- $\alpha$ ), an endogenous endothelial inhibitor. Treatment with IFN- $\alpha$ has become an accepted therapy for inducing regression of hemangioendotheliomas ${ }^{133}$, however the effect of IFN- $\alpha$ in vitro is twofold. It can act directly on endotheliall cell movement by which angiogenesis is inhibited, it can downregulate bFGF mRNA, but it can also potentiate the angiogenic effect of interleukin-2130.146.147.

Platelet factor $4(\mathrm{PF}-4)$ is an example of an agent interfering with a migration inducing factor. PF-4, a high molecular weight inhibitor, is an arginine-rich basic protein of 4,300 molecular weight. The ability of PF-4 to inhibit angiogenesis was originally reported by Taylor and Folkman when they noted that its application to the chorioallantoic membrane of the chick give rise to avascular zones ${ }^{\text {lat }}$. It interferes with the migration inducing factor bFGF ${ }^{130}$. The heparin binding and 
anticoagulant activities of PF-4 cause problems in its use as anti-angiogenic therapy ${ }^{110.11 !}$.

Many agents have been found which interfere in endothelial cell proliferation and inhibit angiogenesis in that way.

Suramin, a polysulfonated urea has been demonstrated to be anti-angiogenic. It binds to growth factors such as members of the FGF family, TGF- $\beta$, EGF, PDGF, VEGF or IGF-1 (insulin growth factor), thus reducing cell division indirectly. Suramin caused accumulation of cells in $\$$-phase. It blocks the activity of aFGF by aggregation of the growth factor in suramin-aFGF multimers with an aFGF to suramin ratio of $2: 1$. This conformational change can interfere with the receptor binding and thereby block the proliferating inducing capacity of aFGF. Suramin has been used to treat cancers that do not respond to conventional chemotherapy. The major problem of suramin is that the dose required to exert antitumor activity often results in severe toxicity $134-13 \%$.

Tamoxifen, an antiestrogen, can be used as therapy in hormonal diseases like breast cancer. It induces apoptosis in the tumor cells. It inhibits estrogens, which normally stimulate cell proliferation. Tamoxifen not only inhibits tumor cell proliferation but also endothelial cell proliferation ${ }^{139-141}$.

Until now 2 endogeneous produced angiogenesis inhibitors are isolated. Angiostatin is a circulating endothelial cell inhibitor that suppresses angiogenesis and numor growth. It is first isolated by O'Reilly et al. in $1994^{132}$. It has more than $98 \%$ identity to a $38 \mathrm{kD}$ internal fragment of plasminogen, whereas the activity of angiostatin resembles that of thrombospondin ${ }^{132,149}$. Angiostatin has been shown to be formed by the cleavage of plasminogen by a serine protease released from prostate tumor cell lines ${ }^{150,151}$. It comprises the first four kringle domains of plasminogen. Lysine binding site-1 (LBS-1), containing the kringles 1 to 3 , has boen shown full activity since kringle 4 does not exhibit inhibition of angiogenesis. The kringle 1-3 fragment even exhibits an increased inhibitory activity compared with kringle $1-4$ (angiostatin) ${ }^{149,152,153}$. It has been shown to bind to vitronectin a factor of the extracellular matrix ${ }^{153}$. Endostatin, an other circulating endothelial cell. inhibitor isolated by $O^{*}$ Reilly is a fragment of collagen XVIII. Systemic therapy with endostatin causes a strong suppression of tumor-induced angiogenesis and the group of Folkman suggests that both angiostatin and endostatin can be used as angiogenesis inhibitors and tumor dormancy therapy ${ }^{131}$. Repeated cycles of endostatin are followed by prolonged tumor dormancy without further therapy and without drug resistance during therapy ${ }^{154}$. 


\section{References}

1. Furcht LT. Critical factors controlling angiogenesis:cell products, cell matrix, and growth factors. Lab Invest 1986;55:505-509.

2. Sidky YA, Auerbach R. Lymphocyte-induced angiogenesis: a quantitative and sensitive assay of the graft-vs-host reaction. J Exp Med 1975; 141:1084-1100.

3. Polverini PI, Cotran RS, Gimbrone MA, Unanue ER. Activated macrophages induce vascular proliferation. Nature 1977;269:804-806.

4. Gospodarowicz D, Thakral KK. Production of a corpus luteum angiogenic factor responsible for the proliferation of capillaries and neovascularization of the corpus luteum. Proc Natl Acad Sci USA 1978;75:847-851.

5. Thakral KK, Goodson WH, Hunt TK. Stimulation of wound blood vessel growth by wound macrophages. I Surg Res 1979;26:430-436.

6. Virchow R. "Die Krankenhaften Geschwülste". August Hirschwald, Berlin 1863. cited by Paweletz $\mathrm{N}$ and $\mathrm{Knierim} \mathrm{M}$ in:Tumor related angiogenesis. Critical reviews in oncology and haematology 1989;9:197-242.

7. Goldmann E. Growth of the malignant disease in man and the lower animals with special reference to wascular system. Lancet 1907:1236 1240.

8. Ehrlich P. Beitrage zur Kenntniss der granulierten Bindlegewebzellen und der cosinophilen leukocyten. Arch Anat Physiol 1879;3:166-169.

9. Paweletz $N$, Knierim M. Tumor-related angiogenesis. Critical reviews in oncology/haematology 1989;9:197-242.

10. Clark ER, Clark EL. Observations on the new growth of lymphatic vessels as seen in transparant chambers introduced into the rabbits ear. Am I Anat 1932;51: 441-447.

11. Wood $\mathrm{S}$. Pathogenesis of metastasis formation observed in vivo in the rabbit ear chamber. Arch Parhol 1958;66:550.

12. Warren BA. Shubik P. The growth and blood supply to melanoma transplants in the hamster check pouch. Today 1987; 10:258.

13. Greenblatt $M$, Shubik P. Tumor angiogenesis: transfilter diffusion studies in the hamster by the transparent chamber technique. J Natl Cancer Inst 1968:41:111-124.

14. Algire GH, Chalkey HW. Vascular reactions of normal and malignant lissues in viwo.l.Vascular reactions of mice to wounds and to normal and neoplastic transplants. I Natl Cancer Inst 1945;6:73-85.

15. Folkman J, Long DM, Becker FF. Growth and metastasis of tumors in organ culture. Cancer 1963;16:453.

16. Knighton D, Ausprunk D, Tapper D, Folkman J. Avascular and vascular phases of tumor growth in the chick embryo. $\mathrm{Br} \int \mathrm{Cancer}$ 1977;35:347-356.

17. Ide $\mathrm{AG}$, Baker $\mathrm{NH}$, Warren $\mathrm{SL}$. Vascularization of the brown-pearce rabbit epithelioma transplant as seen in the transparent ear chamber. Am I Roengenol Radium Ther 1939;42:891.

18. Algire GH. The adaptation of the transparent chamber technique to the mouse. J Natl Cancer Inst $1943 ; 4: 1$. 
19. Gimbrone MA, Cotran RS, Leapman S, Folkman J. Tumor growh and neovascularization: an experimental model using the rabbit cornea. I Natl Cancer Inst 1974:52:413-427.

20. Leighton J. In The spread of cancer. New York: Academic Press, 1967.

21. Sutherland R, Carlsson J, Durand R, Yuhas J. Spheroids in cancer reseach. Cancer Res $1981 ; 41: 2980-2984$.

22. Sutherland RM, Sordat B, Bamat J, Gabbert H, Bourrat B, Mueller-Klieser W. Oxygenation and differentiation in multicellular spheroids of human colon carcinoma. Cancer Res 1986;46:5320-5329.

23. Sutherland RM. Cell and environment interactions in tumor microregions: the multicell spheroid model. Science 1988;240:177-184.

24. Sutherland RM. Importance of critical metabolites and cellular interactions in the biology of microregions of tumors. Cancer 1986;58:1668-1680.

25. Sutherland RM, McCredie JA, Inch WR. Growth of multicell spheroids in tissue culture as a model of nodular carcinomas. J Natl Cancer Inst 1971;46:113-120.

26. Carlsson J, Yuhas JM. Liquid-overlay culture of cellular spheroids. Recent Results Cancer Res 1984; $95: 1-23$.

27. Langer $R$, Folkman J. Polymers for the sustained release of proteins and other macromolecules. Nature 1976;263:797-800.

28. Beekhuizen $H$, Van Furth $R$. Growth characteristics of cultured human macrovascular venous and arterial and microvascular endothelial cells. I Vasc Res. $1994 ; 31: 230-239$.

29. Pepper MS, Montesano R. Proteolytic balance and capillary morphogenesis. Cell differentiation and development 1990;32:319-328.

30. Enenstein J, Kramer RH. Confocal microscopic analysis of integrin expression on the microwasculature and its sprouts in the neonatal foreskin. J Invest Dermatol $1994 ; 103: 381-386$.

31. Montesano R, Vassalli JD, Baird A, Guillemin R, Orci L. Basic fibroblast growth factor induces anglogenes is in vitro. Proc Natl Acad Sci USA 1986;83:7297-7301.

32. Pötgens AlG, Wesphal HR, De Waal RMW, Ruiter DI. The role of vascular permeability factor and basic fibroblast growth factor in tumor angiogenesis. Biol Chem Hoppe Seyler 1995;376:57-70.

33. Griffioen AW, Damen CA. Martinotti S, Blijham GH, Groenewegen G. Endothelial intracellular achesion molecule-1 expression is suppressed in human malignancies: the role of angiogenic factors. Cancer Res $1996 ; 56: 1111-1117$.

34. Montesano $R$, Orci $L$. Tumor-promoting phorbol esters induce angiogenesis in vitro. Cell $1985 ; 42: 469-477$.

35. Montesano R. Regulation of angiogenesis in vitro. Eur J Clin Invest 1992;22: 504-515.

36. Weidner $\mathbf{N}$. Intratumor microvessel density as a prognostic factor in cancer. Am J Pathol 1995;147:9-19.

37. Hillen HFP, Hak LE, Joosten-Achjanie SR, Arends J-W. Microvessel density in unknown primary tumors. Int J Cancer 1997;74:81-85. 
38. Folkman J. Tumor angiogenesis: therapeutic implications. New Engl I Med 1971 ; $285: 1182-1186$.

39. Folkman I, Cole P, Zimmerman S. Tumor behavior in isolated perfused organs: in vitro growth and metastasis of biopsy material in rabbit thyroid and canine intestinal segment. Ann Surg 1966;164:491-502.

40. Gimbrone MA, Leapman SB, Cotran RS, Folkman J. Tumor dormancy in vivo by prevention of neovascularization. J Exp Med 1972:136:261-276.

41. Lien WM, Ackerman NB. The blood supply of experimental hiver metastases. II. A microcirculatory study of the normal and tumor vessels of the liver with the use of perfused silicone rubber. Surgery 1970;68:334-340.

42. Thompson WD, Shiach KJ. Fraser RA, Mclntosh LC, Simpson JG. Tumors acquire their vasculature by vessel incorporation, not vessel ingrowth. I Pathol 1987; $151: 323-332$.

43. Paget $S$. Distribution of secondary growths in cancer of the breast. Lancet 1889 : $571-573$.

44. Ewing J. In Neoplastic diseases: A treatise on tumours. Philadelphia: W.B. Saunders, 1928 .

45. Folkman J. Proceedings: tumor angiogenesis factor. Cancer Res 1974;34: 2109-2113.

46. Folkman I. What is the evidence that tumors are angiogenesis dependent? J Natl Cancer Inst 1990;82:4-6.

47. Less JR, Skalak TC, Sevick EM, Jain RK. Microvascular network architecture in mammary carcinoma. In Angiogenesis Key princïples-science-technology-medicine. Steiner R, Weisz PB, Langer R eds. Basel: Birkhäuser Verlag, 1992: 74-84.

48. Konerding MA, Van Ackern C, Steinberg F, Streffer C. Combined morphological approaches in the study of network formation in tumor angiogenesis.In Angiogenesis: Key principles-Science-Technology-Medicine. Steiner R, Weisz PB, Langer R eds. Basel: Birkhauser Verlag, 1992: 40-58.

49. Endrich $B$, Hammersen F. Messmer $K$. Vascular endothelium in health and disease. In Capillary ultrastructure and microcirculatory function of malignant tumors. Chien S eds. New York: Plenum Press, 1988: 205-214.

50. Rifkin DB, Gross JL, Moscatelli D, Jafte E. Pathobiology of the endothelial cell. In Proteases and angiogenesis: prodcution of plasminogen activator and collagenase by endothelial cells. Nossel HL, Vogels HJ eds. New York: Academic Press, 1982: 191-197.

51. Boucher $Y$, Jain RK. Microvascular pressure is the principal driving force for interstitial hypertension in solid tumors: implications for vascular collapse. Cancer Res 1992;52:5110-5114.

52. Jain RK. Transport of molecules in the tumor interstitum: a review. Cancer Res $1987 ; 47: 3038-3050$.

53. Senger DR, Galli SJ, Dworak AM, Perruzzi CA, Harvey VS, Dvorak HF. Tumor cells secrete a vascular permeability factor that promotes accumulation of ascitis fluid. Science 1983;219:983-985. 
54. Jan RK. Barriers to drug delivery in solid tumors. Scientific American 1994; $271: 58-65$.

55. Orlidge A, D'Amore PA. Inhibition of capillary endothelial cell growth by pericytes and smooth muscle cells. J Cell Biol 1987; 105:1455-1462.

56. Ausprunk DH, Boudreau CL. Nelson DA. Proteoglycans in the microvasculature. 1. Histochemical localization in microvessels of the rabbit eye. Am I Pathol $1981 ; 103: 353-366$.

57. Lichtenbeld HHC, Van Dam-Mieras MCE, Hillen HFP. Tumor angiogenesis: pathophysiology and clinical significance. Neth J Med 1996;49:42-51.

58. Griffioen AW. Phenotype of the tumor vasculature; cell adhesion as a target for tumor therpay. Cancer Journal 1997;10:249-261.

59. Brooks PC. Cell adhesion molecules in angiogenesis. Cancer Metas Rev 1996:15:187-194.

60. Hynes RO and Lander AD. Contact and adhesive specificities in the associations, migrations, and targetting of cells and axons. Cell 1992;68:302-322.

61. Griffioen AW, Damen CA, Blijham GH, Groenewegen G. Tumor angiogenesis is accompanied by a decreased inflammatory response of tumor-associated endothelium. Blood 1996;88:667-673.

62. Kitayama J, Nagawa $H$, Yasuhara $H$, Tsuno $N$, Kimura W, Shibata $Y$, Muto T. Suppressive effect of basic fibroblast growth factor on transendothelial emigration of CD4(+) T-lymphocyte. Cancer Res 1994;54:4729-4733.

63. Hellwig SMM, Damen CA, Van Adrichem NPH, Blijham GH, Groenewegen G, Griftioen AW. Endothelial CD34 is suppressed in human malignancies: role of angiogenic factors. Cancer Letters 1997; 120:203-211.

64. Griffioen AW, Coenen MJH, Damen CA, Hellwig SMM, Van Weering DHJ, Vooys W, Blijham GH, Groenewegen G. CD44 is involved in tumor angiogensis; an activation antigen on human endothelial cells. Blood 1997;90:1150-1159.

65. Brooks PC. Role of integrins in angiogenesis. Eur J Cancer 1996;32a:2423-2429.

66. Brooks PC, Montgomery AMP, Rosenfeld M, Reisfeld RA, Hu T, Klier G, Cheresh DA. Integrin $\alpha \beta_{3}$ antagonists promote tumor regression by inducing apoptosis of angiogenic blood vessels. Cell 1994;79:1157-1164.

67. Trousseau A. Phlegmasia alba dolens. In Clinique Médicalle de L'Hôtell-Dieu de Paris. Trousseau A eds. Paris: Librairie J.-B. Ballière et Fils, 1885: 695-705.

68. Bick RL. Coagulation abnormalities in malignancy: a review. Semin Thromb Hemost 1992; 18:353-372.

69. Soong BCF, Miller SP. Coagulation disorders in cancer. III. Fibrinolysis and inhibitors. Cancer 1970;25:867-874.

70. Brown LF, Lanir $\mathrm{N}$, McDonagh J, Tognazzi $K$, Dvorak AM, Dvorak HF. Fibroblast migration in fibrin gel matrices. Am J Pathol 1993;142:273-283.

71. Dvorak HF, Harvey VS, Estrella P, Brown LF, McDonagh J, Dvorak AM. Fibrin containing gels induce angiogenesis. Implications for tumor stroma generation and wound healing. Lab Invest 1987:57:673-686.

72. Falanga A, Gordon SG. Isolation and characterization of cancer procoagulant: a cysteine proteinase from malignant tissue. Biochemistry $1985 ; 24: 5558-5567$. 
73. Dvorak HF. Tumours: wounds that do not heal. New Engl I Med 1986.315: $1650-1659$.

74. Donati MB, Poggi A. Malignancy and haemostasis. Br I Haematol 1980;44: 173-182.

75. Donati $\mathrm{MB}$. Cancer and thrombosis: from phlegmasia alba dolens to transgenic mice. Thromb Haemost 1995;74:278-281.

76. Gordon SG, Franks JJ, Lewis B. Cancer procoagulant A: a factor $\mathrm{X}$ activating procoagulant from malignant tissue. Thromb Res 1975;6:127-137.

77. Battegay EJ. Angiogenesis: mechanistic insights, neovascular disease, and therapeutic prospects. J Mol Med 1995;73:333-346.

78. Baillie CT, Winslet MC, Bradley NJ. Tumour vasculature- a potential therapeutic target. $\mathrm{Br} \rrbracket$ Cancer $1995 ; 72: 257-267$.

79. Folkman J, Klagsbrun M. Angiogenic factors. Science $1987 ; 235: 442-447$.

80. Folkman J. How is blood vessel growth regulated in normal and neoplastic tissue? GHA Clowes memorial award lecture. Cancer Res 1986;46:467-473.

81. Diaz-Flores L, Gutierrez R, Varela H. Angiogenesis: an update. Histol Histopathol $1994 ; 9: 807-843$.

82. Gospodarowicz D. Localisation of a fibroblast growth factor and its effect alone and with hydrocortisone on T cell growth. Nature 1974;249: 123-127.

83. Gospodarowicz D. Purification of a fibroblast growth factor from bovine pifuitary. J Biol Chem 1975;250:2515-2520.

84. Maciag T, Cerundolo J, llsley S, Kelley PR, Forand R. An endothelial cell growth factor from bovine hypothalamus: identification and partial characterization. Proc Natl Acad Sci USA 1979;76:5674-5678.

85. Maciag T, Mehlman T, Friesel R. Heparin binds endothellial growth factor, the principal endothelial mitogen in bovine brain. Science 1984;225:932-935.

86. Burgess WH, Maciag T. The heparin-binding (fibroblast) growth factor family of proteins. Ann Rev Biochem 1989;58:575-606.

87. Friesel RE, Maciag T. Molecular mechanism of angiogenesis: fibroblast growth factor signal transduction. Faseb J 1995;9:919-925.

88. Baird A, Esch $F$, Mormede $P$, Ueno $N$, Ling $N$, Bolnlen $P$, Ying $S$, Whenrenberg WB, Guillemin R. Molecular characterization of fibroblast growth factor: distribution and biological activities in various tissues. Recent Prog Horm Res $1989 ; 42: 143-205$

89. Dickson C, Peters G. Potential oncogene product related to growth factors. Nature $1987 ; 326: 833$.

90. DelliBovi P, Curatola AM, Kern FG, Greco A, Ittman M, Basilico C. An oncogene isolated by transfection of Kaposi's sarcoma DNA encodes a growth factor that is a member of the FGF family. Cell 1,987;50:729-737.

91. Yoshida T, Miyagawa K, Odagiri H, Sakamoto H, Litte PF, Terada M, Sugimura $T$. Genomic sequence of hst, a transforming gene encoding a protein homologous to fibroblast growth factors and the int-2-encoded protein. Proc Natl Acad Sci USA $1987 ; 84: 7305-7309$. 
92. Zhan X, Bates $B$, Hu $X$, Goldfarb $M$. The human FGF-5 oncogene encodes a novel protein related to fibroblast growh factors. Mol Cell Biol 1988;8:3487-3495.

93. Marics 1, Adelaide J, Raybaud F, Mattei MG, Coulier F, Planche J, Delapeyriere O, Birnbaum D. Characterization of the HST-related FGF-6 gene, a new member of the fibroblast growth lactor gene family. Oncogene 1989;4:335-340.

94. Finch PW, Rubin IS, Miki T, Ron D, Aaronson SA. Human KGF is FGF-related with properties of a paracrine effector of epithelial cell growth. Science $1989 ; 245: 752 \div 755$.

95. Tanaka A, Miyamoto K, Minamino M, Takeda M, Sato B, Matsuo H, Matsumoto K. Cloning and characterization of an androgen-induced growth factor essential for the androgen-dependent growth of mouse mammary carcinoma cells. Proc Natl Acad Sci USA 1992;89:8928-8932.

96. Miyamoto M, Naruo KI, Selko C, Matsumoto S, Kondo T, Kurokawa T. Molecular cloning of a movel cytokine cDNA, encoding the ninth member of the fibroblast growth factor family, which has a unique secretion property. Mol Cell Biol $1993 ; 13: 4251-4259$.

97. Korhonen J, Partanen J, Eerola E, Vainikka S, Alitalo R, Mäkelä TP, Sandberg M, Hirvonen $\mathbb{H}$, Alitola $K$. Five $\mathbb{F G F}$ receptors with distinct expression patterns. In Angiogenesis:Key principles-Science-Technology-Medicine. Steiner R, Weisz PB, Langer $\mathbb{R}$ eds. Switzerland: Birkhauser Verlag Basel, 1992:91-100.

98. Penaul-Liorca $F$, Bertucci $F$, Adélaïde $J$, Parc $P$, Coulier $F$, Jaquemier J, Birnbaum D, DeLapeyrière $O$. Expression of FGF and FGF receptor genes in human breast cancer. Int I Cancer 1995;61:170-176.

99. Slavin J. Fibroblast growth factors: at the heart of angiogenesis. Cell Biol Int $1995 ; 19: 431-444$.

100. Folkman J. Angiogenesis and breast cancer. J Chin Oncol 1994;12:441-443.

101. Hori A, Sasada R, Matsutani E, Naito K, Sakura Y, Fujita T, Kozai Y. Suppression of solid tumor growth by immunoneutralizing monoclonal antibody against human basic fibroblast growth factor. Cancer Res 1991,51:6180-6184.

102. Barendsz-Janson AF, Griffioen AW, Muller AD, Van Dam-Mieras MCE. Hillen HFP. In vitro tumor angiogenesis assays: plasminogen lysine binding site 1 inhibits in vitro tumor induced angiogenesis. J Vasc Res 1998;35:109-11.4.

103. Wang $Y$, Becker D. Antisense targeting of basic fibroblast growth factor and fibroblast growth factor receptor-1 in human melanomas blocks intratumoral angiogenes is and tumor growth. Nat Med 1997;3:887-893.

104. Ferrara N. Henzel WJ. Pituitary follicular cells secrete a novel heparin-binding growth factor specific for vascular endothelial cells. Biochem Biophys Res Commun $1989 ; 161: 851-858$.

105. Takeshita S, Zheng LP, Brogi E, Kearney M, Pu LQ, Bunting S, Ferrara N, Symes JF, Isner IM. Therapeutic angiogenesis. A single intraarterial bolus of vascular endothel ial growth factor augments revascularization in a rabbit ischemic hind limb model. I Clin Invest 1994;93:662-670.

106. Mustonen T, Alitalo K. Endothelial receptor tyrosine kinases imwolved in angiogenesis. I Cell Biol 1995;129:895 898. 
107. Goto F, Goto K, Weindel K, Folkman J. Synergistic effects of vascular endothehal growth factor and basic fibroblast growth factor on the proliferation and cord formation of bovine capillary endothelial cells within collagen cells. Lab Invest $1993 ; 69: 508-517$.

108. Kim KJ, Li B, Winer J, Armanini M, Gillett N, Phillips HS, Ferrara N. Inhibition of vascular endothelial growth factor-induced anglogenesis suppresses turnour growth in vivo. Nature $1993: 362: 841-844$.

109. Spyridopoulos I, Brogi E, Kearney M, Sullivan AB, Cetrulo C, Isner JM, D.W. L. Vascular endothelial growth factor inhibits endothelial cell apoptosis induced by tumor necrosis factor- $\alpha$ : balance between growth and death signals. I Mol Cell Cardiol 1997;29:1321-1330.

110. Bicknell $R$. Vasculat targetting and the inhibition of angiogenesis. Ann Oncol $1994 ; 5: 45-50$.

111. Craft PS, Harris AL. Clinical prognostic significance of tumor anglogenesis. Ann Oncol 1994;5:305-311.

112. Dvorak HF, Brown LF, Detmar M, Dvorak AM. Vascular permeability factor/vascular endothelial growth factor, microvascular hyperpermeability, and angiogenesis. Am f Pathol 1995;146:1029-1039.

113. Ellis LM, Fidler IJ. Angiogenesis and metastasis. Eur J Cancer 1996;32a: $2451-2460$.

114. Mukhopadhyay D, Tsiokas L, Sukhatme VP. Wild-type p53 and v-Src exert opposing influence on human vascular endothelial growth factor gene expression. Cancer Res 1995;55:6161-6165.

115. Millauer B, Shawver LK, Plate KH, Risau W, Ullich A. Glioblastoma growth inhibited in vivo by a dominant-negative Flk-1 mutant. Nature 1994;367:576-579.

116. Tsurumi $Y$, Murohara $T$, Krasinski $K$, Chen $D$, Witzenbichler B, Kearney $M$, Couffinhal $T$, Isner JM. Reciprocal relation between VEGF and $N O$ in the regulation of endothelial integrity. Nat Med 1997;3:879-886.

117. Abedi $H$, Zachary I. Vascular endothelial growth factor stimulates tyrosine phosphorylation and recruitment to new focal adhesions of focal adhesion kinase and paxillin in endothelial cells. I Biol Chem 1997;272:15442 1545l.

118. Fett JW, Strydon DJ, Lobb RF, Alderman EM, Betheme IL. Isolation and characterization of angiogenin an angiogenic protein for human carcinoma cells. Biochem 1985;24:5480-5486.

119. Rao CV, Li X, Toth P, Lei ZM. Expression of epidermal growth factor, transforming growth factor-alpha, and their common receptor genes in human umbilical cords. J Clin Endocr Metab 1995:80:1012-1020.

120. Sporn MB, Roberts AB, Wakefield LM, Assoian RK. Transforming growth factor-beta: biological function and chemical structure. Science 1986;233:532-534.

121. Beutler B. Cerami A. Cachectin and tumour necrosis factor as two sides of the same biological coin. Nature 1986;320:584-588. 
22. Arteaga $C L$, Hurd $\mathrm{SD}$, Winnier AR, Johnson MD, Fendly BM, Forbes JT, Anti-transforming growth factor (TGF)- $\beta$ antibodies inhibit breast cancer cell tumorigenicity and increase mouse spleen natural killer cell activity. Implications for a possible role of tumor cell/host TGF- $\beta$ interactions in human breast cancer progression. J Clin Invest 1993:92:2569-2576.

123. Pepper MS, Vassalli JD, Orci L, Montesano R. Biphasic effect of transforming growth factor- $\beta 1$ on in vitro angiogenesis. Exp Cell Res 1993;204:356-363.

124. Leibowich SJ, Polverini PJ, Shepard HM, Wiseman DM, Shively V, Nuseir N. Macrophage-induced angiogenesis is mediated by tumour necrosis factor-alpha. Nature 1987;329:630-632.

125. Norrby K. TNF-alpha and de novo mammalian angiogenesis. Microvascular Research 1996;52:79-83.

126. Lewis $\mathrm{CE}$, Leek $\mathrm{R}$, Harris A, McGee JO. Cytokine regulation of angiogenesis in breast cancer: the role of tumor-associated macrophages. I Leukocyte Biol 1995; $57: 747-751$.

127. Koolwijk P, Van Erck MGM, De Vree WJA, Vermeer MA, Weich HA, Hanemaaijer $R$, Van Hinsbergh VWM. Cooperative effect of TNF $\alpha$, bFGF, and VEGF on the formation of tubular structures of human microvascullar endothelial cells in a fibrin matrix. Role of urokinase activity. J Cell Biol 1996;132:1177-1188.

128. Fukumura D, Salehi HA, Witwer B, Tuma RF, Melder RJ, Jain RH. Tumor necrosis factor $\alpha$-induced leukocyte adhesion in normal and tumor vessels: effect of tumor type, transplantation site, and host strain. Cancer Res 1995;55:4824-4829.

129. Yoshida $S$, Ono $M$, Shono $T$, Izumi $H$, Ishibashi $T$, Suzuki $H$, Kuwano $M$. Involvement of interleukin-8, vascular endothelial growth factor, and basic fibroblast growth factor in tumor necrosis factor alpha-dependent angiogenesis. Mol Cell Biol 1997; 17:4015-4023.

130. Auerbach W, Auerbach R. Angiogenesis inhlubition: a review. Pharmac Ther 1994; $63: 265-311$.

131. O'Reilly MS, Boehm T, Shing Y, Fukai N, Vasios G, Lane WS, Flynn E, Birkhead JR, Olsen BR, Folkman J. Endostatin: an endogenous inhibitor of angiogenesis and tumor growth. Cell 1997:88:277-285.

132. O'Reilly MS, Holngren L, Shing Y, Chen C, Rosenthal RA, Moses M, Lane WS, Cao Y, Sage $\mathbb{E H}$, Folkman J. Angiostatin: a novel angiogenesis inhibitor that mediates the suppression of metastases by a Lewis Lung carcinoma. Cell 1994:79:315-328.

133. Ezekowitz RAB, Mulliken JB, Folkman J. Interferon alfa-2a therapy for Uife-threatening hemangiomas of infancy. New Engl J Med 1992;326:1456-1463.

134. Pesenti E, Sola F, Mongelli N, Grandi M. Spreafico F. Suramin prevents neovascularisation and tumour growth through blocking of basic fibroblast growth factor activity. Br I Cancer 1992;66:367-372.

135. Behrendt $\mathrm{N}$, Rønne $\mathrm{E}$, Dano $\mathrm{K}$. Binding of the urokinase-type plasminogen activator to its cell surface receptor is inhibited by low doses of suramin. J Biol Chem $1993 ; 268: 5985-5989$. 
136. Sato Y, Rifkin DB. Autocrine activities of basic fibroblast growth factor: regulation of endothelial cell movement, plasminogen activator synthesis, and DNA synthesis. J Cell Biol 1988;107:1199-1205.

137. Braddock PS, Hu D-E, Fan T-PD, Stratford IJ, Harris AL, Bicknell R. A structure-activity analysis of antagonism of the growth factor and angiogenic activity of basic fibroblast growth factor by suramin and related polyanions. $\mathrm{Br} \int \mathrm{Cancer}$ $1994 ; 69: 890-898$.

138. Morris AD, Léonce $S$, Guilbaud $N$, Tucker GC, Pérez V, Jan M, Cordi AA, Pierré A, Atassi G. Eriochrome Black T, structuraly related to suramin inhibits angiogenesis and tumor growth in wivo. Anti-Cancer Drugs 1997:8:746-755.

139. Chen $H$, Tritton TR, Kenny N, Absher M, Chiu J-C. Tamoxifen induces TGF- $\beta 1$ activity and apoptosis of human $\mathrm{MCF}-7$ breast cancer cells in vitro. I Cell Biochem 1996;61:9-17.

140. Chalbos D, Vignon $F$, Keydar $I$, Rochefort $H$. Estrogens stimulate cell proliferation and induce secretory proteins in a human breast cancer cell bine (T47D), J Clin Endocrinol Metab 1982;55:276-283.

141. Gasparini G. Angiogenesis research up to 1996. A commentary on the state of art and suggestions for future studies. Eur J Cancer 1996;32a:2379-2385.

142. Sledge GW, Qulali $M$, Goulet $R$, Bone $\mathbb{E} A$, Fife $R$. Effect of matrix metalloproteinase inhibitor batimastat on breast cancer regrowth and metastas is in athymic mice. J Natl Cancer Inst 1995;87:1546-1550.

143. Fisher $C$, Gilbertson-Beadling $S$, Powers EA, Petzold $G_{4}$ Poorman R, Mitchell MA. Interstitial collagenase is required for angiogenesis in vitro. Dev Biol $1994 ; 162: 499-510$.

144. Rasmussen HS, McCann PP. Matrix metalloproteinase inhibition as a novel anticancer strategy: a review with special focus on batimastat and marimastat. Pharmacol Ther 1997; 75:69-75.

145. Lami JS, Lowe SW, Licitra EI, Liu JO, Jacks T. p53-independent apoptosis induced by paclitaxel through an indirect mechanism. Proc Natl Acad Sci USA 1997:94:9679-9683.

146. Parangi $S$, O'Reilly M, Christofori G, Holmgren L, Grosfeld J, Folkman J, Hanahan D. Antiangiogenic therapy of transgenic mice impairs de novo tumor growth. Proc Natl Acad Sci USA 1996;93:2002-2007.

147. Majewski S, Marczak M, Szmurlo A, Jablonska S, Bollag W. Retinoids, interferon $\alpha, 1,25$-dihydroxyvitamin $\mathrm{D}_{3}$ and their combination inhibit angiogenesis induced by non-HPV-harboring tumor cell lines. RAR $\alpha$ mediates the antiangiogenic effects of retinoids. Cancer Lett 1995;89:117-124.

148. Taylor $\mathrm{S}$, Folkman J. Protamine is an inhibitor of angiogenesis. Nature 1982; 297:307-312.

149. O'Reilly MS, Holmgren L, Shing Y, Chen C, Rosenthal RA, Cao Y, Moses M, Lane WS, Sage EH, Folkman J. Angiostatin; a circulating endothelial cell inhibitor that suppresses angiogenesis and tumor growth. Cold Spring Harbor Symposia on Quantitative Biology, 1994:471-482. 
150. Gately $\mathrm{S}$, Twardowski P. Stack MS, Parrick M, Boggio L, Cundiff DL, Schnaper HW, Madison L, Volpert O, Bouck N, Enghild J, Kwan HC. Soff GA. Human prostate carcinoma cells express enzymatic activity that converts human plasminogen to the angiogenesis inhibitor, angiostatin. Cancer Res 1996;56: $4887-4890$.

151. Sunassee K. Vile R. Tumour angiogenesis: Hitting cancer where it hurts. Current Biology $1997 ; 7: R 282-R 285$.

152. Cao Y, Ji RW, Davidson D, Schaller J, Marti D, Söhndal S, McCance SG, O'Reilly MS, Llinás M, Folkman J. Kringle domains of human angiostatin. Characterization of the anti-proliferative activity on endothelial cells. J Biol Chem $1996 ; 271: 29461-29467$.

153. Kost $C$, Benner $K$, Stockmann A, Linder D, Preissner KT. Limited plasmin proteolysis of vitronectin. Characterization of the adhesion protein as morpho-regulatory and angiostatin-binding factor. Eur I Biochem 1996;236: $682-688$

154. Boehm $T$, Folkman $J$, Browder $T$, O'Reilly MS. Antiangiogenic therapy of experimental cancer does not induce acquired drug resistance. Nature 1997; 390:404-407. 


\section{Chapter 2}

\section{Introduction to the experimental work}




\section{Introduction to the experimental work}

New vessel formation (angiogenesis) is important for the expansion of tumors. Inhibition of angiogenesis may, therefore, provide a novel strategy in cancer treatment. Angiogenesis is a multi-step process which involves activation, mobility, proliferation and apoptosis of endothelial cells and the interaction of endothelial cells, plasma factors and the surrounding extracellular matrix. A variety of antiangiogenesis therapies directed at specific steps in the angiogenic cascade has now been developed.

Several in vitro and in vivo models have been used up to now for the study of angiogenesis. Most of these models, however, are restricted to distinct stages in the angiogenic cascade and only generate data on proliferation or migration of endothelial cells. One of the aims of the work described in this thesis was to develop a reliable in vitro tumor-angiogenesis model, based on EC tube formation in a collagen gel, which involves most of the successive stages of the angiogenic cascade. Such a model could be useful for both the study of the fundamental mechanisms of tumor angiogenesis and for the study of drugs aimed at antiangiogenesis therapy.

Tumor cell lines were used for the induction of angiogenesis in the in vitro model. To this end the characteristics of the angiogenesis inducing cell lines have to be determined. After characterization of the in vitro angiogenesis model different drugs could be tested for their (possible) angiogenesis inhibiting capacity. However, during new vessel formation in vivo, factors like immune defense, tissue repair and cell adhesion play a role also. These aspects are not covered in the in vitro model. For that reason a mouse model was used to investigate the in vivo aspects and effects on new vasculature formation. Comparison of the in vivo obtained results with the results from the in vitro angiogenesis assay, may evidence the strength of the use of the in vitro assay to test drugs for cancer therapy.

The first experimental study, described in chapter 3, focusses on the growth characteristics of rumor cell lines. In order to develop an in vitro tumorangiogenesis model it was important to initially investigate the relevant in vitro growth characteristics of the tumor cell lines. In cancer patients tumors grow as a clump of cells embedded in an extracellular matrix. In vitro, however, most of the experiments are performed on monolayer cultures of tumor cells in which contact with an extracellular matrix is absent. Maybe such differences in the microenvironment of the tumor cells can influence their growth characteristics. In vitro cells can be cultured as multicellular spheroids, which mimics the in vivo growth of a tumor. When those spheroids have a diameter of $250 \mu \mathrm{m}$ or more, they develop a necrotic core surrounded by viable cells, a phenomenon which has also been reported in the in vivo situation. It has been suggested that the necrotic 
core and the hypoxia within it can initiate the secretion of angiogenic factors. This phenomenon is obviously absent in monolayer cultures. This difference in growth configuration may also influence other characteristics, such as tumor cellproliferation. For that reason we investigated the influence of cellular configuration (monolayer versus spheroid growth) and matrix composition on growth characteristics and on some potential prognostic markers in three different breast cancer cell lines. Because it is known that hormone receptor levels in breast tumors strongly influence the growth characteristics in vivo, we studied two estrogen and progesterone receptor positive cell lines (T47D and MCF-7) and one estrogen and progesterone receptor negative cell line (Hs578T).

The extracellular matrix plays an important role in the tube formation. On the one hand the extracellular matrix offers the supporting network for the newly formed vessels, on the other hand the matrix has to be degraded for the migration of EC and the invasion of the newly formed vessels into the extracellular matrix. Coagulation plays a role in matrix formation. For that reason we determined the expression of factor X, factor Xa, tissue factor, antithrombin III and von Willebrand Factor which are involved in the formation of a fibrin matrix. For matrix degradation proteolytic enzymes are important. We determined the expression of the plasminogen activators and their inhibitor PAI because these factors regulate the level of expression of plasmin which is able to degrade the matrix. Angiostatin, a derivative of plasminogen, is able to inhibit angiogenesis, which suggests another role of proteases in the new wessel formation. Coagulation and fibrinolytic factors are expressed by endothelial cells as well as by tumor cells. For that reason the expression of coagulation factors and proteolytic enzymes by the tumor cells has been investigated.

The tumor cells were cultured on different matrices, a collagen gel and an agarose matrix to study their capacity to form spheroids. Proliferation markers and (indirect) apoptosis markers were determined in the spheroids as well as in the cells cultured as monolayer. The receptor positive cell lines (T47D and MCF-7) were able to form spheroids whereas the negative cell line (Hs578T) grew invasively through the collagen gel and did not grow at all in the agarose matrix. In the in vitro angiogenesis assay the cells had to be inoculated into the gel as spheroids and therefore, only the receptor positive cells could be used because the receptor negative cell line degraded the matrix and could not be cultured as spheroids. From the monolayers as well as the spheroids, culture conditioned medium was prepared. In this conditioned medium the expression of coagulation factors and proteolytic enzymes was determined in order to study the effects of cellular configuration on these parameters.

Subsequently we developed an in vitro angiogenesis model based on the formation of tubes in a collagen based three-dimensional gel system. In this model the process 
of angiogenesis induction could be varied. The studies to develop a reliable model system are described in chapter 4 . Briefly, the endothelial cells were cultured on a layer of a semi-natural matrix of type I collagen. In vitro tube formation, angiogenesis, could be induced by the addition of conditioned medium on top of the EC or by adding spheroids or tumor biopsies to the system. In the first approach, conditioned medium was prepared from tumor cell lines cultured as monolayers. At confluence the tumor cell monolayers were incubated for 24 hours with fresh medium to obtain conditioned medium. The second possibility was the addition of tumor cell line spheroids or biopsies to the system. The endothelial cells could be cultured in a one-well model in which endothelial cells and angiogenesis stimulator are in one compartment or in a transwell model in which the compartment with the EC and the angiogenesis inducer are in contact with each other via a filter.

The conditioned medium of Hs578T cells (which cannot be grown as spheroids), together with the conditioned media and spheroids from the cell lines T47D, MCF7 and LS174T (colon carcinoma) and biopsies from breast cancer patients were used. In this study we also included the LS174T cell line because, from literature, it is known that this cell line should induce angiogenesis. In all cases angiogenesis could be induced in the in vitro assay although the angiogenic inducing capacity differed considerably. The model in which angiogenesis was induced by the conditioned medium of the breast cancer cell line Hs578T appeared to be the most reliable and reproducible. In this model we tested the known angiogenesis inhibitor angiostatin.

After developing the in vitro angiogenesis model, the effects of different anti-tumor drugs and anti-angiogenic factors were determined (chapter 5). We measured the effects of anti-tumor drugs on angiogenesis to see if those drugs were able to inhibit tumor growth via their influence on the angiogenic process in addition to the direct anti-tumor effect. We, therefore, compared the effects of these drugs on three different EC types with those on different tumor cell lines and furthermore we compared their effects with those of known angiogenesis inhibitors. The effects of six drugs ( 3 anti-angiogenic and 3 anti-tumor drugs) were first tested in the in vitro angiogenesis assay. After the effect in the angiogenesis assay was evaluated, their effect on proliferation and apoptosis was determined to unravel the possible mechanism behind the angiogenesis inhibition. The results obtained in three types of endothelial cells were compared with the effects on three tumor cell lines to study the differences between a cytostatic and a cytotoxic effect.

The antineoplastic drugs suramin and suradista are the objects of study in chapter 6. Suramin induces cytotoxicity in tumor cells. One of the major problems in 
clinical use is the small therapeutical window, that is the difference between the dose which is required for an effective tumor inhibition and that leading to severe toxicity. For that reason an analog of suramin with similar anti-tumor activity but substantially lower toxicity would be very valuable. We investigated and compared the effects of suramin and its analog suradista, on human endothelial cells, bovine endothelial cells, and the three tumor cell lines T47D, Hs578T and LS174T. To investigate the possible mechanism of action of both compounds the effects on angiogenesis, proliferation and apoptosis were tested.

In the in vitro assay no systemic factors are included, and because of this we also decided to develop an in vivo tumor-induced angiogenesis model. Chapter 7 describes this in vivo angiogenesis model, using the dorsal skin fold chamber in immunodeficient mice. In the chamber an angiogenesis inducer could be inoculated and the angiogenic process could be followed over time. In this model the angiogenic inducing potential of various tissues of the human breast was evaluated. The aim of this study was to determine if it was possible to discriminate, with respect to angiogenesis inducing capacity between healthy, premalignant and malignant tissue. Biopsies from normal breast tissue, from hyperplastic tissue, from tumor tissue and from histologically normal tissue present in the affected breast were studied. The biopsies were xenografted in the dorsal skin fold chamber and their angiogenesis inducing capacity was evaluated. Before the biopsies were inoculated in the dorsal skin fold chamber they were kept for a few days in medium. In the conditioned media obtained the expression of the prognostic marker VEGF was determined. The various types of tissues showed different angiogenesis inducing capacity which correlated well with the in vitro production of VEGF.

In chapter 8 the conclusions which can be drawn from this work are discussed. 


\section{Chapter 3}

\section{Cellular arrangement of human breast cancer cell lines determines hemostatic parameters}

AF Barendsz-Janson, AD Muller, HHC Lichtenbeld, MCE van Dam-Mieras, HFP Hillen

Tumor Biol, 1998: 19; 104-1/2 


\section{Abstract}

Two in vitro models are compared to investigate whether cellular configuration or composition of the marrix in which the cells are cultured influences growth and/or prognostic parameters.

T47D, MCF-7 and Hs578T breast cancer cell lines were cultured on two different matrices (agarose and collagen). Growth curves, biological markers (Ki-67, p53 and bcl-2) and the expression of hemostatic parameters were studied. The tested hemostatic parameters were urokinase-type plasminogen activator, tissue-type plasminogen activator and plasminogen activator inhibitor as fibrinolytic parameters and von Willebrand factor, tissue factor, antithrombin III, factor $\mathrm{X}$ and factor $\mathrm{Xa}$ as coagulation parameters. We found that T47D and MCF-7 formed spheroids in both matrices. Hs578T did not form spheroids; instead, the cells remained single cells in one matrix and grew invasively through the other matrix. Expression of the biological markers was similar for spheroids and monolayers. In contrast, a clear difference in expression of hemostatic factors by spheroids and monolayers was found. 


\section{Introduction}

Breast cancer causes significant morbidity and mortality especially among middle aged women ${ }^{1}$. Breast carcinoma is a heterogeneous neoplasm made up of different cell types with different growth rates, invasive capacity and metastatic potential. This is one reason why clinical behavior may widely differ among patients with comparable pathology or clinical stage ${ }^{2}$. The clinical variation is associated with biological properties of the primary tumor like receptor status, ploidy and tumor cell growth ${ }^{3}$. The clinical heterogeneity may also depend on the interactions of tumor cells and tumor stroma. In recent literature, the regulating function of the extracellular matrix in tumor growth and metastasis has been emphasized ${ }^{4}$. Defects of hemostasis in patients with cancer have long been recognized ${ }^{5,6}$. Heterogeneity of invasion and metastasis of breast cancer may be associated with (local) hemostatic and fibrinolytic factors in (tumor) vessels and extracellular matrix? Better insight into these mechanisms is needed to understand the biology of breast cancer and may offer new targets for therapeutic interventions.

Several in vitro models to study tumor biology have been developed over the years. These models include tumor cells grown in monolayers and models using tumor cell spheroids. An advantage of the systems using monolayers is that they are easy to prepare and to handle. Models using spheroids, on the other hand, seem to have the advantage that they more closely mimic the in vivo situation. Multicellular spheroids are composed of tumor cells growing in a three-dimensional structure ${ }^{8,9}$. When they reach a certain size, the internal cells become diffusion limited and consequently necrotic, resembling most of the in vivo avascular tumor nodules ${ }^{\mathrm{x}}$. Tumor spheroids could thus be considered intermediate between in vitro monolayers and in vivo tumors ${ }^{B_{10}}$.

The aim of the present work was to compare the growth characteristics of three different tumor cell lines in a monolayer system and a spheroid system. In the spheroid system two different matrices were used, a collagen iype I matrix and an agarose matrix. The collagen matrix forms a simple equivalent of the in vivo environment and can enzymatically be degraded by tumor cells. Agarose constitutes an inert matrix which cannot easily be degraded by tumor-cell derived enzymes.

As tumor cells, we used two hormone dependent cell lines, i.e. the estrogen (ER) and progesterone receptor (PR) positive cell lines T47D and MCF-7, and one hormone independent cell line, Hs578T. Growth was determined morphologically and some common prognostic parameters of breast cancer were assayed: proliferation marker $\mathrm{Ki}-67^{11}$, DNA repair protein $\mathrm{p} 53^{12}$, the apoptotic index marker bcl-2 $2^{12.13}$, the proteolytic enzymes urokinase-type plasminogen activator 
(uPA) and tissue-type plasminogen activator ( $\mathrm{PA}$ ) and their inhibitor plasminogen activator inhibitor 1 (PAI-1) $)^{14,15}$ and factors involved in coagulation like von Willebrand factor $(\mathrm{vWF})^{16}$, tissue factor $(\mathrm{TF})^{17,18}$, factor $\mathrm{X}$, factor $\mathrm{Xa}^{9}$ and antithrombin III $^{19}$.

\section{Materials and methods}

\section{Tumor cells}

Three human breast cancer cell lines were used T47D, MCF-7 and Hs578T. T47D and Hs578T cells were obtained from the European Collection of Animal Cell Culture (ECACC, Salisbury, UK), the MCF-7 cells from the American Type Culture Collection (ATCC, Rockville, Md., USA).

T47D and MCF-7 cell lines are ER and PR positive. The cell lines were maintained in Dulbecco's Modified Essential Medium (DMEM; Life Technologies, Breda, The Netherlands) supplemented with $10 \%$ fetal bovine serum (Boehringer Ingellheim, BioWhittaker, Verviers, Belgium), $50 \mathrm{IE} / \mathrm{ml}$ penicillin and $50 \mathrm{ng} / \mathrm{ml}$ streptomycin (ICN, Zoetermeer, The Netherlands) ${ }^{20,21}$.

Hs578T is ER and PR negative ${ }^{20.22}$. The PR status was tested by standard protocols at the Department of Pathology at the University Hospital Maastricht. The Netherlands, with a monoclonal antibody: human PR protein clone $1 \mathrm{A6}$ (Thamee Diagnostika). The Hs578T cells were cultured in DMEM with $4.5 \mathrm{~g} / \mathrm{l}$ glucose, supplemented with $10 \%$ fetal bovine serum, $2 \mathrm{mM}$ glutamine $(\mathbb{I C N}), 10 \mu \mathrm{g} / \mathrm{ml}$ insullin (Life Technologies), $50 \mathrm{IE} / \mathrm{ml}$ penicillin and $50 \mathrm{ng} / \mathrm{ml}$ streptomycin. Cells were screened for mycoplasm by PCR.

\section{Spheroid growth}

Spheroids were grown as described by Lichtenbeld et al. ${ }^{9}$ and Olea et al. ${ }^{23}$. Briefly, cells were harvested from exponentially growing cultures by trypsinization. Single cell suspensions were embedded in a seminatural matrix of collagen type $\mathbb{1}(2.4$ $\mathrm{mg} / \mathrm{ml}$ vitrogen, Collagen Corporation) or a structural inert matrix $(0.25 \%$ agarose; Sigma St. Louis, Mo., USA) in 24- or 96-well plates (500 and $100 \mu \mathrm{l}$, respectively; Costar, Cambridge, UK). About 100 cells (in a 96-well plate) or 1000 cells (in a 24-well plate) per well were embedded in the matrix. Culture plates were incubated at $37^{\circ} \mathrm{C}$ with $5 \% \mathrm{CO}_{2}$, and every third day, mediurn was changed. Individual spheroids were measured $(\mathrm{n}=40)$, using a calibrated scale in the eyepiece of a Zeiss inverted microscope (Carl Zeiss b.v. Weesp, The Netherlands). Growth curves were established. 


\section{Determination of Ki-67, p53 and bcl-2}

Immunohistochemical stainings were performed on spheroids and monolayers. Spheroids were fixed for 1 hour at room temperature in $4 \%$ neutral buffered formalin and embedded in paraffin; subsequently, $2 \mu \mathrm{m}$ sections were cut and placed on 3-aminopropyltriethoxysilane-coated glass slides. The monolayers were washed with phosphate-buffered saline (PBS), harvested with trypsin-EDTA and washed again with PBS. Cytospin preparations of these single cells were made with a cytospin centrifuge (Cyto-tek; Ames-Miles Division, Bayer, The Netherlands). The cytospins were fixed in $4 \%$ neutral buffered formalin for $30 \mathrm{~min}$, rinsed with distilled water and air dried. Cells were stained for p53, Ki-57 and bel-2 following the methods of Friedrich et al. ${ }^{24}$ and Cattoretti et al. ${ }^{25,26}$. The antibodies used were MIB-1 (1:100, $1 \mathrm{~h}$. at room temperature; Dianova, Hamburg, Germany) for staining of the nuclear protein Ki-67, Do-7 (1:500, 2 h. at room temperature; Dako ITK Diagnostics, Uithoorn, The Netherlands) for the p53 mutant staining and antibcl-2 (anti-human bcl-2 oncoprotein clone 124, 1:100, 2 h. at. room temperature; Dako ITK Diagnostics). Per staining, 1200 cells or 12 spheroids were counted.

\section{Determination of fibrinolytic factors}

Tumor cell monolayers were grown until confluence on tissue culture plastics. Subsequently the conditioned medium was removed, centrifuged and stored at $-80^{\circ} \mathrm{C}$. Conditioned medium from spheroid cultures was also harvested and stored at $-80^{\circ} \mathrm{C}$. The level of plasminogen activator and PAI, expressed in the conditioned medium of the cell cultures, was determined by commercially available ELISAs from Biopool ( $n=6$; Kordia Laboratory Supplies, Leiden, the Netherlands).

\section{Determination of coagulation parameters}

The coagulation parameters were determined in the conditioned media of the cell line monolayers and the spheroids $(n=6)$. Factor $X$ and $X a$ determination was carried out according to the method of Lichtenbeld et al. ${ }^{9}$, that of antithrombin III according to the method of Bas et al. ${ }^{19}$ and that of WWF according to the method of Bruggeman et al. ${ }^{16}$. Tissue factor expression was determined by a clotting time assay ${ }^{17}$ and a chromogenic assay ${ }^{18}$.

\section{Results}

The cytospins prepared from confluent monolayers of all three cell lines were immunohistochemically stained for the clinical markers Ki-67, p53 and bcl-2. The results are summarized in table 3.1. All three cell lines stained positively for the proliferation marker Ki-67; the invasively growing Hs578T cells displayed the 
highest level of the marker. T47D and Hs578T cells showed positive staining for p53 and no staining at all for bcl-2, while the MCF-7 cell line showed the opposite.

Table 3.1 Percentage of positive staining for the prognostic markers Ki-67, p53 and bcl-2 on three cell lines cultured in the monolayer system.

\begin{tabular}{llll}
\hline & Ki-67 & p53 & bcl-2 \\
\hline T47D & $55 \%$ & $83 \%$ & $0 \%$ \\
MCF-7 & $59 \%$ & $2 \%$ & $77 \%$ \\
Hs578T & $76 \%$ & $60 \%$ & $0 \%$ \\
\hline
\end{tabular}

The results of the hemostatic parameters determined in the conditioned media of the monolayer cultures are shown in tables 3.2 and 3.3 . Table 3.2 shows increased expression of $\mathrm{TF}$ and factor Xa when compared to the control medium. Other parameters are the same in the tumor samples as in the control medium. Table 3.3 showed that the Hs578 $\mathrm{T}$ cell line was the only one which expressed considerable proteolytic activity. Small amounts of UPA were detected for the two other cell lines. These also produced PAI-1, whereas the tPA expression was below the detection limit.

Table 3.2 Coagulation factors determined in the conditioned medium of the monolayers of the three breast cancer cell lines $\left(2.5 \times 10^{6}\right.$ cells $)$.

\begin{tabular}{lccccc}
\hline & vWF (units) & TF (\%) & factor X (\%) & factorXa(\%) & AT III (\%) \\
\hline T47D & 0.43 & 36.5 & 5.5 & 100 & 4.0 \\
MCF-7 & 0.42 & 36.3 & 5.7 & 100 & 3.6 \\
Hs578T & 0.39 & 31.3 & 5.1 & 42.3 & 2.8 \\
control $^{*}$ & 0.38 & 0 & 4.0 & 5.3 & 4.5 \\
\hline
\end{tabular}

- Control is unconditioned medium. 
Table 3.3 Amounts of plasminogen activators and their inhibitors in conditioned medium of tumor cell monolayers $\left(2.5 \times 10^{\circ}\right.$ cels $)$.

\begin{tabular}{llll} 
& uPA & tPA & PAI \\
\hline T47D & 0.1 & n.d. & 7.5 \\
MCF-7 & 0.85 & n.d. & 7.5 \\
Hs578T & 8.8 & 7.0 & 660 \\
\hline
\end{tabular}

Results are given in $\mathrm{ng} / \mathrm{ml}$ conditioned medium. (n.d.=not detectable). In conditioned medium of spheroids it was below the detection limit.
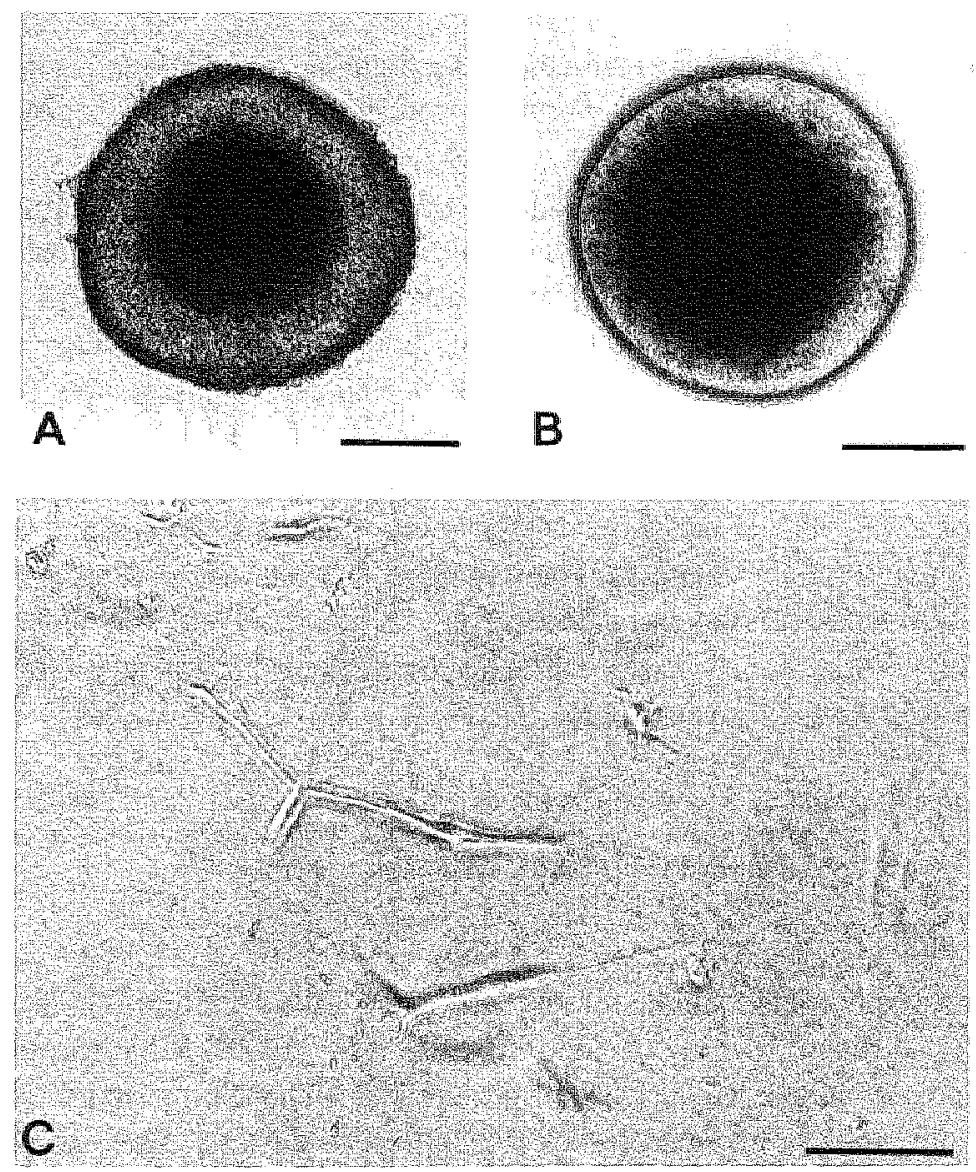

Figure 3.1 Growth of the tumor cells in vitrogen. A. T47D spheroids of 37 days, B. MCF-7 spheroids of 37 days, C. Invasive growth of Hs578T cells. ( Seale bar $=150 \mu \mathrm{m})$ 


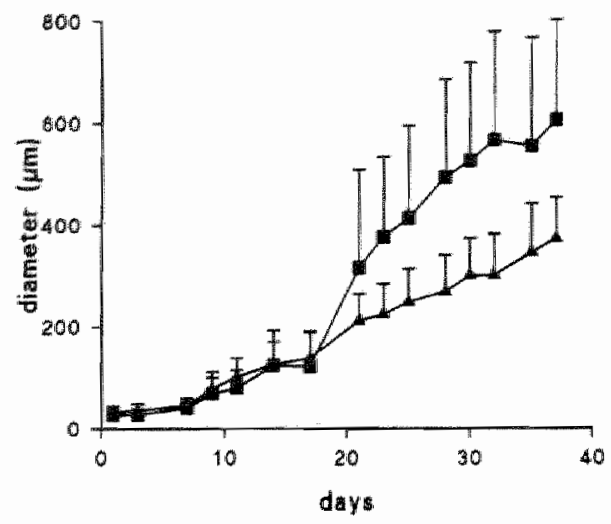

Figure 3.2 Growth curve of the cell line T47D in days. Spheroids cultured in agarose ( or vitrogen ( 4 ). (Mean value of 40 spheroids \pm s. )

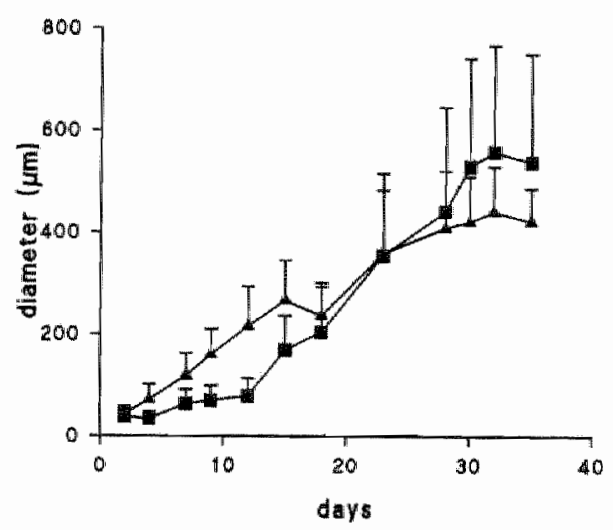

Fugure 3.3 Growth curve of the cell line $\mathrm{MCF}_{-7}$ in days. Spheroids cultured in agarose (w) or vitrogen $(4)$. (Mean value of 40 spheroids $\pm \mathrm{s.d}$.)

To grow spheroids, single tumor cells were either cultured in a collagen type 1 matrix (vitrogen) or in an inert agarose gel. T47D cells formed spheroids in collagen as well as in agarose (figure 3.1A). The Gompertzian growth curve of these spheroids is given in figure 3.2. After 18 days, the growth-rate of spheroids in agarose exceeded the growth-rate of spheroids in collagen (not significant). MCF-7 also formed spheroids in collagen as well as in agarose (figure 3.1B). The growth curve of these spheroids is given in figure 3.3. This cell line showed growth curves similar to the T47D cell line. 
In contrast, the cell line Hs578T did not form spheroids in a collagen matrix, but rather invaded the matrix (figure $3.1 \mathrm{C}$ ). To verify whether the invasive growith of Hs.578T cells in the collagen matrix was caused by the specific collagen preparation (vitrogen), the cells were also grown in a collagen matrix from a different source (collagen type I; Harbor Bioproducts, Norwood, Mass., USA and Sanvertech, The Netherlands). Also, in that collagen matrix the cells were growing invasively and no spheroids could be obtained. In agarose, Hs578T cells did not form spheroilds either, but remained single cells even after 30 days. To exclude the possibility that compounds in the specific agarose preparation were responsible for this effect, the cells were also cultured in two other types of agarose (Indubiose A37 agarose, L'Industrie Biologique Francaise, France; Agarose Orco, Behringwerke AG, Germany). In these agarose-gels the same results were obtained. When the cells were cultured in a mixed agarose/collagen-gel, they invaded the matrix just as in the collagen matrix.

Conditioned media from spheroid cultures were harvested and stored at $-80^{\circ} \mathrm{C}$. At day 37 , the spheroids were fixed and embedded in paraffin. Slices were stained for Ki-67, p53 and bcl-2. Positive staining was found only in the rim of viable cells surrounding the necrotic center (12 spheroids per staining counted). The staining patterns were the same as those obtained with monolayer cultures (table 3.1).

In the conditioned media, the coagulation and fibrinolytic parameters were determined. The expression of the plasminogen activators and PAI- 1 was below the detection limit. The results of the coagulation parameter determinations are summarized in table 3.4. T47D spheroids still expressed (small) amounts of TF and factor Xa, but this was strongly decreased when compared to monolayer cultures. TF and factor Xa expression by MCF-7 spheroids decreased to the control level.

Table 3.4 Coagulation factors determined in the conditioned medium of spheroids of the two breast cancer cell lines.

\begin{tabular}{lccccc}
\hline & vWF (units) & TF $(\%)$ & factor X $(\%)$ & factorXa(\%) & AT III (\%) \\
\hline T47D & 0.38 & 1.8 & 5.3 & 22.9 & 2.4 \\
MCF-7 & 0.37 & 0.3 & 3.5 & 9.0 & 5.2 \\
control" & 0.33 & 0 & 4.3 & 9.5 & 5.4 \\
\hline
\end{tabular}

" Control is medium conditioned on vitrogen without cells. 


\section{Discussion}

Several in vitro tumor models have been developed over the years. In this study, two models are compared to see whether the configuration of the cells or the matrix in which the cells are cultured influences growth and/or prognostic parameters.

The results of the cell lines T47D and MCF-7 showed that the matrix in which the cells were cultured as spheroids did not influence the growth rate of the cells or the expression of all the other parameters measured because in the agarose matrix, the same results were obtained as in the collagen matrix. The Hs578T cell line was not able to form spheroids in both matrices. It is known that patients with ER negative tumors have an unfavorable prognosis because these tumors more often grow invasively and form metastases than ER positive tumors. This is apparently in agreement with results obtained in the vitrogen culture, where the ER negative line grows invasively and the $\mathbb{E R}$ positive lines form more encapsulated tumors ${ }^{3}$.

When the expression of the markers exposed in and on the cells was compared, no differences between spheroids and monolayers were found, which is in agreement with the results of Okada et al ${ }^{27}$. It can be concluded that the matrix in which the cells were grown, and the configuration (monolayer versus spheroids) did not influence the expression of Ki-67, p53 and bcl-2 by the tumor cells. All staining patterns found on spheroids and cytospins were in agreement with the literature ${ }^{11-13}$.

The fibrinolytic and coagulation factors present in the culture media were also determined (tables 3.2-4). There were cllear differences between the conditioned media from the monolayer cultures and those from the spheroid cultures of both the cell lines T47D and MCF-7. As Hs578T cells do not form spheroids they are not included in table 3.4 .

Because the culture media contained serum, which can disturb the coagulation experiments, samples of media without conditioning were used as controls. The results showed that cells cultured as monolayers only secrete TF and factor Xa. All other factors were at the level of the control medium. For the spheroids, only the T47D cell line excreted small amounts of TF and factor $X \mathrm{a}$ when compared to control media (conditioned on vitrogen without cells). But just as for MCF-7, T47D spheroids expressed less coagulation factors than the monolayers. We speculated that the coagulation factors could be bound to the matrix in which the spheroids were cultured. For that reason, we tested the conditioned medium of spheroids cultured in medium. We did not find any differences in the expression of coagulation factors in the conditioned medium from spheroids cultured in medium or vitrogen. 
When cells die, they disintegrate into vesicles. In the monolayer culture, these vesicles remain in the media, whereas in the spheroid culture, they can stick to the matrix. It is possible that these vesicles, when present in the medium, disturb the experiments, which is another explanation for the decrease in coagulation factor expression in spheroid culture. For that reason, the samples of the conditioned media were centrifuged $\left(1 \mathrm{~h} ., 25000 \mathrm{~g}, 4^{\circ} \mathrm{C}\right)$ and determined again. No differences with the results obtained without centrifugation were found. We therefore suggest that the configuration may influence the secretion of coagulation parameters.

Notable for all parameters tested is the Hs578T cell line. This cell line did not form spheroids, neither in vitrogen nor in agarose. In vitrogen, invasive growth was observed, while in agarose the cells remained single cells. When the cells were cultured in a mixture of collagen and agarose-gel, the cells also invaded the matrix. An explanation for this observation may be sought in the interaction between adhesive receptors on the tumor cells and structures in the extracellular matrix which could be present in the collagen matrix, but absent in the agarose matrix. The expression of adhesion molecules and integrin subunits differs between the cell lines. For example, E-cadherin is absent in the Hs578T cell line, while it is present in the other two cell lines ${ }^{3.28-30}$.

The Hs578T cells were growing invasively through the collagen matrix. In this invasive growth, the matrix degrading capacity of the cells may also be involved. These cells expressed 10-90 times the amount of uPA and extremely high levels of PAI- 1 when compared to the two ER/PR positive cell lines. The high amounts of PAI- 1 expression correlate with the in vivo results of Foekens et al. ${ }^{31}$ who showed that high PAI-1 expression was associated with a poor prognosis in patients with primary breast cancer. He suggested that in breast cancer PAI-1 can be produced as a mechanism of self-protection against the UPA induced tissue destruction.

Our ER and PR positive cell lines produced only small amounts of PAI-1, which is in agreement with the results of Foekens et al. ${ }^{15}$ which showed that in ER and PR positive tumors, PAI-1 levels were more often negative. Our results suggest at relation between proteolytic activity as determined in conditioned media and the growth behavior of the cell lines in the collagen matrix. These findings suggest that the proteolytic activity generated by the Hs578T cell line favored matrix invasion over spheroid formation. A last remarkable result is the difference in the amount of coagulation factors when the conditioned media of the monolayer cultures of the ER-negative and ER-positive lines are compared. In conditioned medium from the Hs578T cell line less factor $\mathrm{Xa}$ is found than in that from the two ER positive lines. Also, the amount of TF is decreased when compared to the other two cell lines. Our results with the Hs578T line may explain that bleeding (decreased 
clotting factors) is sometimes associated with the occurrence of wide-spread malignant disease ${ }^{32}$ which correlates with the results of the Hs578T line.

We conclude that for in vitro studies both models are reliable, but it has to be kept in mind that the configuration of the cell culture can influence the results. Furthermore, not all cell lines do form spheroids in matrices and a possible relationship between the tendency or lack to form spheroids, the generation of proteolytic activity and invasiveness certainly deserves further study. 


\section{References}

1. Abeloff MD, Lichter AS, Niederhuber JE, Pierce LJ, Aziz DC. Breast. In Clinical Oncology. Abeloff MD, Armitage JO, Lichter AS, Niederhuber JE eds. New York: Churchill Livingstone, 1995: 1617-1714.

2. Gasparini $G$, Harris AL. Clinical importance of the determination of tumor angiogenesis in breast carcinoma: Much more than a new prognostic tool. \& Clin Oncol 1995:13:765-782.

3. Thompson EW, Paik $S$, Brünner $N$, Sommers $C L$, Zugmaier $G$, Clarke R, Shima TB, Torri J, Donahue S, Lippman ME, Martin GR, Dickson RB. Association of increased basement membrane invasiveness with absence of estrogen receptor and expression of vimentin in human breast cancer cell lines. I Cell Physiol 1992*150: 534-544.

4. Lochter A, Bissell MJ. Involvement of extracellular matrix constituents in breast. cancer. Sem in Cancer Biol 1995;6:165-173.

5. Tannock IF. Population kinetics of carcinoma cells, capillary endothelial cells , and fibroblasts in a transplanted mouse mammary tumor. Cancer Res 1970;30: $2470-2476$.

6. Trousseau A. Phlegmasia alba dolens. In Clinique Médicale de L'Hôtel-Dieu de Paris. Trousseau A eds. Paris: Librairie J.-B. Ballière et Fils, 1885: 695-705.

7. Nierodzik ML, Klepfish A, Karpatkin S. Role of platelets, thrombin, integrin IIb-IIlla, fibronectin and von Willebrand factor on tumor adhesion in vitro and metastasis in vivo. Thromb and Haemost 1995;74:282-290.

8. Sutherland R, Carlsson J, Durand R, Yuhas J. Spheroids in cancer reseach. Cancer Res 1981:41:2980-2984.

9. Lichtenbeld HHC, Muller AD, Van Dam-Mieras MCE, Blijham GH. Tumor spheroid-induced vesicle formation on endothelial cells is associated with procoagulant properties. J Cell Science 1993; 106:657-662.

10. Sutherland RM, McCredie JA, Inch WR. Growth of multicell spheroids in tissue culture as a model of nodular carcinomas. J Nat Cancer Inst 1971;46:113-120.

1. Porter-Jordan $\mathrm{K}$, Lippman ME. Overview of the biologic markers of breast cancer. Hematol. Oncoll Clim North Am 1994;8:73-100.

12. Haldar $S$, Negrini $M$, Monne $M$, Sabbioni S, Croce CM. Down-regulation of bel-2 by p53 in breast cancer cells. Cancer Res 1994;54:2095-2097.

13. Leek RD, Kaklamanis L, Pezzella F, Gatter KC, Harris AL. bc-2 in normal human breast and carcinoma, association with oestrogen receptor-positive, epidermal growth factor receptor-negative tumours and in situ cancer. $\mathrm{Br} J \mathrm{Cancer} 1994 ; 69$ : $135-139$.

14. Duffy MI, Reilly D, McDermote E* O'Higgins N, Fennelly JI, Andreasen PA. Urokinase plasminogen activator as a prognostic marker in different subgroups of patients with breast cancer. Cancer 1994;74:2276-2280.

15. Foekens JA. Schmitt M, VanPutten WLJ, Peters HA, Bontebal M, Jänicke F, Klijn JGM. Prognostic value of urokinase-type plasminogen activator in 671 primary breast cancer patients. Cancer Res 1992;52:6101-6105. 
16. Bruggeman CA, Debie WHM, Muller AD, Schute B, Van Dam-Mieras MCE. Cytomegalowirus alters the von Willebrand factor content in human endothelia! cells. Thromb and Haemost 1988;59:264-268.

17. Muller AD, Lichenbeld HHC, Blijham GH, Vossen RCRM, Van Dam-Mieras MCE. Mast cell lysate induces a procoggulant effect on endothelial cells. Thromb Res $1993 ; 72: 263-267$.

18. Pouplard C, Reverdiau-Moalic P, Piquemal R, Watier H, Lebranchu $Y$, Bardos P, Gruel $Y$. A simplified and low-cost one-stage chromogenic assay for tissue factor dependent procoagulant activity of endothelial cells. Thromb Res 1995;80:527-534.

19. Bas BM, Costongs GMPJ, Janson PCW. Rapid analysis of coagulation parameters by automated substrate methods with a Cobas Bio Centrifugal analyser. Haemostasis $1987 ; 17: 260-267$.

20. Engel LW, Young NA. Human breast carcinoma cells in continuous culture: A review. Cancer Res 1978;38:4327-4339.

21. Soule HD, Vazquez J, Long $A$, Albert $S$, Brennan $M$. A human cell line from a pleural effusion derived from a breast carcinoma. J Natl Cancer Inst 1973;51; $1409-1416$.

22. Hacket AJ, Smith HS, Springer EL, Owens RB, Nelson-Rees WA, Riggs JL, Gardner MB. Two syngeneic cell lines from human breast tissue: the aneuploid mammary epithelial (Hs578T) and the diploid myoepithelial (Hs578Bst) cell lines. I Natl Cancer Inst 1977;58:1795-1806.

23. Olea $\mathbb{N}$, Villalobos $M$, Ruiz de Almodówar JM, Pedraza V. MCF-7 breast cancer cells grown as multicellular spheroids in vitro: effect of $17 \beta$-estradiol. Int. J. Cancer 1992;50:112-117.

24. Friedrich $K$, Dimmet $V$, Haroske $G$, Loßnitzer $A$, Kasper $M$, Theissig $F$, Kunze KD. Expression of p53 and bcl-2 in correlation to clinicopathological parameters, hormone receptor status and DNA ploidy in breast cancers. Pathol Res Pract 1995; $191: 1114-1121$.

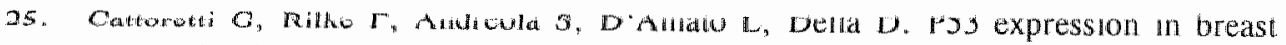
cancer. Int J Cancer 1988:41:178-183.

26. Cattoretti G. Becker MHG, Key G, Duchrow M. Schluter C, Galle J, Gerdes J. Monoclonal antibodies against recombinant parts of the Ki-67 antigen (MIBI and MIB3) detect proliferating cells in microwave processed formalin fixed paraffin sections. I Pathol 1992;168:357-363.

27. Okada $N$, Fushimi $M$, Nagata $Y$, Fukunaga $T$, Tsutsumi $Y$. A quantitative in vivo method of analyzing humar tumor-induced angiogenesis in mice using agarose microencapsulation and hemoglobin enzyme-linked immunosorbent assay. Jpn. I. Cancer Res 1995:86:1182-1188.

28. Gui GPH, Puddefoot JR, Vinson GP, Wells CA, Carpenter R. In witro regulation of human breast cancer cell adhesion and invasion via integrin receptors to the extracellular matrix. Br J Surg 1995;82:1192-1196. 
29. Stadler E, Dziadek M. Extracellular matrix penetration by epithelial cells is influenced by quantitative changes in basement membrane components and growth factors. Exp Cell Res 1996;229:360-369.

30. Sommers $C L$, Gelmann EP, Kemler $R$, Cowin $P$, Byers $S W$. Alterations in $\beta$-catenin phosphorylation and plakoglobin expression in human breast cancer cells. Cancer Res 1994;54:3544-3552.

31. Foekens JA, Schmitt M, Van Putten WLJ, Peters HA, Kramer MD, Janicke F, Klijn JGM. Plasminogen activator inhibitor-1 and prognosis in primary breast cancer. IClin Oncol $1994 ; 12: 1648-1658$.

32. Donati $\mathrm{MB}$, Poggi $\mathrm{A}$, Semeraro N. Coagulation and malignancy. In Recent advances in blood coagulation. Poller $\mathbb{L}$ eds. Edinburgh: Churchill Livingstone, 1981: 227-259. 


\section{Chapter 4}

\section{In vitro tumor angiogenesis assays: plasminogen lysine binding site 1 inhibits in vitro tumor induced angiogenesis}

AF Barendsz-Janson, AW Griffioen, AD Muller, MCE van Dam-Mieras, HFP Hillen

$J$ Vasc Res 1998:35:109-114 


\begin{abstract}
It is generally accepted that tumors are angiogenesis dependent. For research and clinical purposes it would be very attractive to have a simple in vitro model that allows a rapid screening of the angiogenic potential of tumors and to study the effect of angiogenic inhibitors. In vitro angiogenesis models were developed, based on endothelial sprouting/ tube formation on a collagen gel, using both tumor cell lines and tumor biopsies. Best results were obtained using conditioned medium of tumor cell lines. In this model it was found that the plasminogen fragment Lysine Binding Site 1 (LBS-1) inhibited in vitro endothelial cell sprouting. This is the first demonstration that LBS-1, which includes angiostatin, is inhibitory for new vessel formation in an in vitro angiogenesis model. We conclude that the assay system allows for rapid and reliable screening of angiogenesis inhibitors.
\end{abstract}




\section{Introduction}

Angiogenesis is a prerequisite for tumor growth ${ }^{1,2}$. Newly formed vessels are crucial for the supply of oxygen and nutrients to the tumor, for the removal of waste products from the tumor and for the formation of distant metastases. However, how tumor angiogenesis and angiogenesis in general are regulated is under investigation both in vivo $0^{3,4}$ and in vitro ${ }^{5,6}$. In the search for anti-tumor agents, anti-angiogenic therapeutics have shown promising results ${ }^{7}$ although major barriers still remain ${ }^{8}$. For research and clinical practice it would be very attractive to have a simple and reliable in witro model that allows a rapid screening of the angiogenic potential of tumors and to estimate the effect of angiogenic inhibitors. Our ultimate objective is the development of such a screening model. We therefore compared endothelial cell sprouting and tube formation induced by tumor cell lines in different in vitro systems and subsequently investigated the angiogenic potential of different breast cancer tumor biopsies in these systems.

One of the recently discovered angiogenesis inhibitors is angiostatin, discovered in 1994 as an endogenous inhibitor of angiogenesis in tumor bearing animals". Angiostatin comprises the first four kringle domains of plasminogen. Lysine binding site 1 (LBS-1), containing the kringles $\mathbb{\|}$ to 3 , has been shown full activity since kringle 4 does not exhibit inhibition of angiogenesis. The kringle 1-3 fragment even exhibits an increased inhibitory activity compared with kringle 1-4 (angiostatin $)^{10,11}$. Angiostatin has been shown to inhibit in vivo tumor growth by upregulation of apoptosis in tumor cells while the proliferation fraction remains unchanged in these tumors ${ }^{12,13}$. We found that LBS-1/angiostatin is a powerful angiogenesis inhibitor as measured on in vitro endothelial cell sprouting and tube formation.

\section{Materials and methods}

\section{Cell cultures}

The bovine microvascular endothelial cells (BMEC) were used as an endothelial cell source and were kindly provided by Dr. M. Furie (State University of New York, Stony Brook, USA). The cells were routinely grown on $0.2 \%$ gelatin coated dishes in alpha Minimum Essential Medium (alpha-MEM, Life Technologies, Breda, The Netherlands) supplemented with $15 \%$ Donor Calf Serum (DCS, Flow Laboratories, Irvine,UK) $50 \mathrm{IE} / \mathrm{ml}$ penicillin and $50 \mathrm{ng} / \mathrm{ml}$ streptomycin.

Three breast cancer cell lines (T47D, MCF-7 and Hs578T) and one colon cell line (LS174T) were used. T47D, Hs578T and LS174T cells were obtained from the European Collection of Animal Cell Cultures (ECACC, Salisbury, UK), MCF-7 
cells from the American Type Culture Collection (ATCC, Rackville, MD, USA). T47D, MCF-7 and LS174T cell lines were maintained in Dulbecco's Modified Essential Medium (DMEM, Life Technologies) supplemented with $10 \%$ fetal bovine serum (FBS, Boehringer Ingelheim, BioWhittaker, Verviers, Belgium), $50 \mathrm{IE} / \mathrm{ml}$ penicillin and $50 \mathrm{ng} / \mathrm{ml}$ streptomycin $(\mathrm{ICN}$, Zoetermeer, The Netherlands). The Hs578T cell line was cultured in DMEM with $4.5 \mathrm{~g} / 1$ glucose supplemented with $10 \% \mathrm{FBS}, 2 \mathrm{mM}$ glutamine (ICN), $50 \mathrm{IE} / \mathrm{ml}$ penicillin and $50 \mathrm{ng} / \mathrm{ml}$ streptomycin. Tumor cells were grown as spheroids ${ }^{14}$ or as monolayers. Conditioned medium of these cell lines was prepared by addition of fresh culture medium on confluent cell layers and subsequent culture for another 24 hours. Conditioned medium is centrifuged to get rid of cells and debris. All cells were screened for mycoplasma.

\section{One well culture system}

The semi-natural matrix of collagen type $\mathbb{I}$ was prepared by mixing 8 volumes vitrogen-100 (Collagen Corporation, Fermont, CA, USA) with 1 volume 10x concentrated MEM ( Life Technologies) and 1 volume of sodium bicarbonate $(11.76 \mathrm{mg} / \mathrm{ml})^{15}$. The matrix was dispensed into plastic culture dishes $(300 \mu 1$ in a 48-well plate; Costar, Cambridge, UK) and allowed to gel at $37^{\circ} \mathrm{C}$. Confluent BMEC were trypsinized and seeded on top of this matrix $\left(1 \times 10^{5}\right.$ cells/well $)$. To induce sprouting in this system spheroids or tumor biopsies were embedded into this matrix (before gelation). In some experiments conditioned medium $(0.5 \mathrm{ml} /$ well $)$ or medium supplemented with $25 \mathrm{ng} / \mathrm{ml}$ basic fibroblast growth factor (bFGF) (Life Technologies) was added on top of the gel.

\section{Transwell system}

The transwell culture plates (24 Clear-wells, Costar, Cambridge, UK) consists of an insert with a polyester mesh bottom (pore size $0.4 \mu \mathrm{m}$ ). In this insert the collagen matrix $(100 \mu \mathrm{l})$ was added and after gelation BMEC were seeded on top of it. In the lower well chamber spheroids, conditioned medium or human breast cancer biopsies (approximately $8 \mathrm{~mm}^{3}$ ) were added.

\section{Angiogenesis inhibition assay}

BMEC were seeded on a semi-natural collagen matrix gel in a 48-well tissue culture plate. When cells were grown to a confluent monolayer medium of cultures was changed by either fresh culture medium, the Hs578T culture medium (both controls) or with the Hs578T conditioned medium $(0.5 \mathrm{ml} /$ well $)$ and subsequently LBS-1 (Sigma) was added to the BMEC cultures. In some experiments LS174T spheroids were cultured in medium until they had a size of $300 \mu \mathrm{m}$ and were subsequently embedded in the collagen gel. Endothelial cells were seeded on top of 
the gel and LBS-1 was added after 24 hours of incubation. In both experiments the (sprouting) endothelial monolayers were photographed with a Zeiss inverted phasecontrast photomicroscope after 24 hours of incubation with LBS-1. For the spheroid model the sprouting is also evaluated after 4 days. The amount of sprouting in each well (e.g. the total length of sprouts) was quantified by the computer program NIH image 1.58 .

The number of viable cells in the monolayers incubated with LBS-1 was determined using the neutral red assay according to Lowik et al. "Neutral red (3-amino-7-dimethylamino-2-methyl-phenazine hydrochloride; $\mathrm{Cl}$ 50040) was obtained from Sigma. The optical density of the control/untreated cells was set at $100 \%$.

Statistical significance of differences was tested by Anova analysis followed by a Bonferroni Multiple Comparisons Test.

\section{Results}

\section{In vitro induction of angiogenesis}

\section{Conditioned medium system}

To set a reference value for BMEC sprouting, BMEC monolayers cultured on top of a collagen matrix gel were incubated with a known angiogenesis stimulator $\mathrm{bFGF}^{6}$. Incubation of BMEC for 24 hours with $25 \mathrm{ng} / \mathrm{ml} \mathrm{bFGF}$ was able to induce sprouting. Next the sprouting-inducing capacity of conditioned media from tumor cell line cultures was investigated. Plain culture medium was used as control. The amount of sprouting induced with bFGF was set at $100 \%$. Tube formation induced with conditioned media is presented as percentage of the bFGF induced sprouting. The results (figure 4.1) show that the strongest induction of sprouting was found with conditioned medium from the Hs578T cell line. Sprouting occurred within 24 hours.

\section{Tumor spheroid system}

Since it is known that for instance the LS174T cell line is able to induce sprouting in vivo ${ }^{4}$ we allso decided to study tumor cell line induced sprouting in another in vitro system using spheroids instead of conditioned medium of the cell lines. Spheroids were made from the lines T47D, LS174T and MCF-7; the Hs578T cells could not be grown as spheroids ${ }^{17,18}$.

First spheroids were cultured in medium until they had a spheroid size of approximately $300 \mu \mathrm{m}$ and subsequently they were embedded in a collagen matrix. After gelation the BMEC were added on top of the gel. Under these conditions the MCF-7 spheroids induced marginal sprouting, the sprouting induced by the T47D 
spheroids was intermediate while the LS174T spheroids induced the highest amount of sprouting (measured after 3 days) (figure 4.2 ). No tube formation was observed in the control gels not containing spheroids.

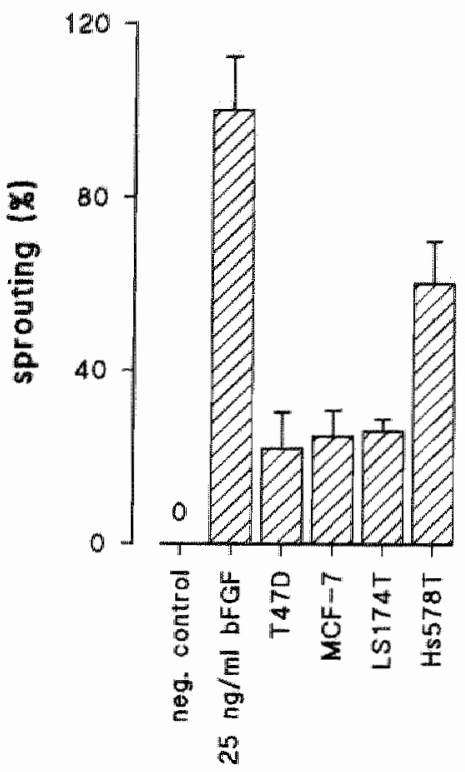

Figure 4.1 The amount of sprouting of BMEC induced by the conditioned media of the cancer cell lines T47D. MCF-7, LS174T and Hs578T. Negative control is the $B M E C$ layer incubated with unconditioned medium. Positive control is 24 hours incubation of BMEC with $25 \mathrm{ng} / \mathrm{mll}$ bFGF. This amount of wbe formation is set at $100 \%$. Sprouting induced by the conditioned media is presented as percentage of the bFGF induced sprouting (mean $\pm \mathrm{sem} ; n=4)$.
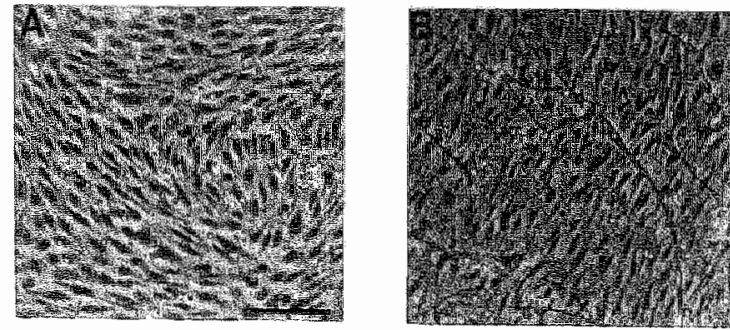

Figure 4.2 Induction of sprouting induced by spheroids of the cell line LS174T. A:control BMEC without spheroids. B: BMEC cultured in the presence of LS174T $(t=7$ days). For both conditions the BMEC are cultured on a fresh matrix. (Scale bar $=100 \mu \mathrm{m})$ 
Second, when spheroids were grown in the collagen matrix gel until they had a spheroid size of $300 \mu \mathrm{m}$, which is after approximately 24 days, sprouting was induced in all spheroid containing gels but in the control gels as well. Some differences were found between spheroid induced and control sprouting but they were not clear-cut. We argued that this might be due to the age of the gel.

\section{Tumor biopsy/transwell system}

In a following series of experiments, tumor biopsies $(n=7)$ were embedded in the collagen matrix to investigate their angiogenic potential. The results of these experiments could not be evaluated since (1) the biopsy material degraded the matrix and (2) the outgrowth of the biopsy in the matrix prevented a proper discrimination between tumor-derived cells and BMEC. In an attempt to bypass these problems a transwell system was used $(n=7)$. In that system we also found sprouting of BMEC in control experiments and furthermore the results were highly variable. Therefore we were not able to work with the transwell setting as a reliable and reproducible assay system.

\section{Angiogenesis inhibition}

As our final objective is the development of an assay to measure the angiogenic potential of tumors and the influence of angiogenesis inhibitors, we decided for reasons of simplicity to use the "conditioned media system" for the investigation of angiogenesis inhibition. We used conditioned medium from the Hs578T cell line to establish standardized in vitro sprouting in order to study the influence of the angiogenesis inhibitor LBS-1 on the sprouting process. Pretreatment of BMEC with $0.5 \mu \mathrm{g} / \mathrm{ml}$ LBS-1 for 24 hours, before Hs578T conditioned medium was added, inhibited the sprout formation completely (figure 4.4). Addition of LBS-1 $(0.5 \mu \mathrm{g} / \mathrm{ml})$ and Hs578T conditioned medium to the BMEC simultaneously showed some sprouting but it was reduced significantly (mean reduction $76 \%$ ) when compared to cultures without inhibitor (figure 4.3 and 4.4). Under these conditions sprouting was completely absent when higher concentrations $(5,15$ and $30 \mu \mathrm{g} / \mathrm{ml})$ of LBS-1 were used. Similar results were obtained when sprouting was induced by LS174T spheroids instead of Hs578T conditioned medium. LBS-1 at 5 and 30 $\mu \mathrm{g} / \mathrm{ml}$ quantities inhibit $100 \%$ of BMEC sprouting. Because BMEC are sensitive to the effects of endotoxin (bacterial lipopolysaccharide, LPS) which is a common contamination of protein preparations, the presence of endotoxin in the LBS-1 preparation is determined with the Limulus amoebocyte lysate assay (Kabi Diagnostica). Only trace amounts of $6.5 \mathrm{fg}$ to $0.39 \mathrm{pg}$ LPS per well were present. To be sure LPS did not interfere in the assay, LPS was titrated to up to $40 \mathrm{pg} / \mathrm{well}$ into the in vitro angiogenesis assay with $\mathrm{LS} 174 \mathrm{~T}$ spheroids as angiogenesis inducer. After incubation periods for up to 4 days all endothelial cells were viable and no inhibitory effects were found on sprouting of endothelial cells (data not shown). 

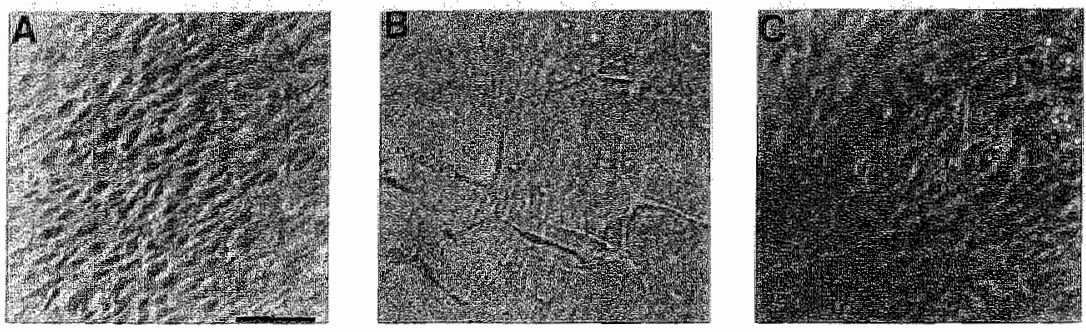

Figure 4.3

The effect of LBS-1 on sprouting. A: BMEC with unconditioned medium. B: BMEC cultured with Hs578T conditioned medium. C: BMEC cultured in the presence of $\mathrm{Hs} 578 \mathrm{~T}$ conditioned medium and LBS- $1(0.5 \mu \mathrm{g} / \mathrm{ml})$. A significant decrease in sprouting can be seen after addition of LBS-1. (Scale bar $=100 \mu \mathrm{m}$ )

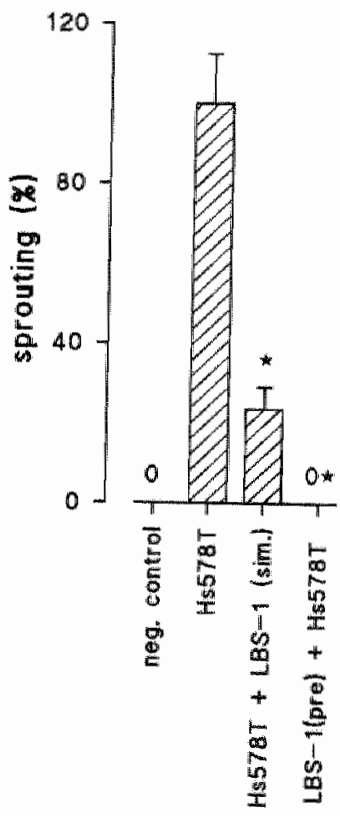

Figure 4.4 Percentage of sprouting of BMEC in the presence of Hs578T conditioned medium and LBS-1 $(0.5 \mu \mathrm{g} / \mathrm{ml})$. Negative control $=$ BMEC cultured without conditioned medium. HS578T $=$ positiwe control; BMEC cultured in the presence of $14578 T$ conditioned medium (set at $100 \%$ ). Sim. $=$ simultaneous addition of Hs578T conditioned medium and LBS-1 $(0.5 \mu \mathrm{g} / \mathrm{ml})$ to the BMEC. Pre = BMEC incubated with LBS $-1(0.5 \mu \mathrm{g} / \mathrm{ml})$; Hs578T conditioned medium is added atter 24 hours. Given is the mean of three experiments with the sem. Results identitied with an asterisk are significanily decreased from cultures with Hs578T conditioned medium only. 
To investigate the specificity of the effect of LBS-1 on the growth characteristics of endothelial cells, BMEC and all tumor cells were grown in the presence of increasing concentrations of LBS-1. After 24 hours of culture the cell number was determined with the neutral red assay. We found a decrease in number of BMEC at concentrations of $5 \mu \mathrm{g} / \mathrm{ml}$ and higher while concentrations of up to $30 \mu \mathrm{g} / \mathrm{ml}$ did not inhibit the tumor cell lines (figure 4.5).

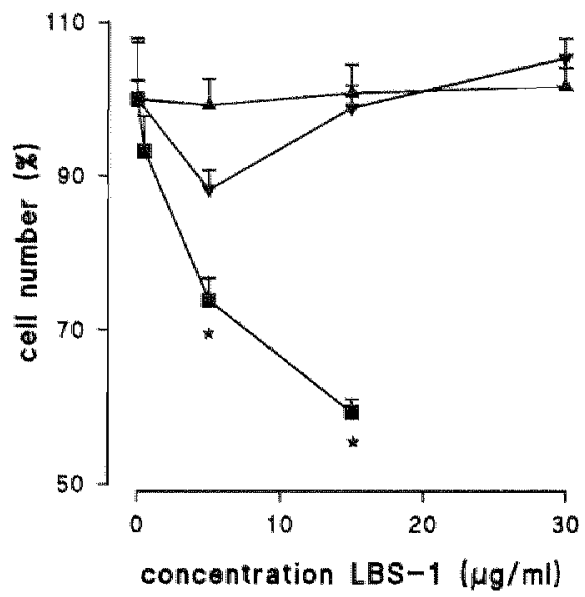

Figure 4.5 Cell number (\%) of BMEC ( $), \operatorname{MCF}-7(4)$ and LS 174T (v) cells after incubation with LBS-1 for 24 hours (mean \pm s.e.m.; tunnor $n=3$; BMEC $n=6$ ). A significant decrease in cell number is tound for the BMEC $(*=p<0.05)$

\section{Discussion}

Angiogenesis is a complex process which involves endothelial cell activation ${ }^{19}$ because endothelial cells are the cells from which new capillaries are formed. How tumor angiogenesis is regulated is still far from clear ${ }^{3,4,6,20}$ but its importance for the development of a tumor is evident $t^{1,2}$. Our objective was to develop an assay system in which we can determine the angiogenic potential of umors and cell lines on the one hand and compare the anti-angiogenic effects of inlhibitory compounds on the other. Since measurement of endothelial cell proliferation only reveals information on one step of the angiogenesis cascade, we wanted to approach a more functional aspect of vessel formation. In developing such an assay system we compared the following in vitro models for endothelial cell sprout formation: (1) BMEC cultured on a matrix gel in the presence of tumor cell conditioned medium (2) BMEC cultured on a gel with tumor cell spheroids or tumor biopsies in the gel and (3) BMEC cultured on a gel in the upper compartment of a transwell system with tumor cell spheroids and tumor biopsies in the lower compartment. 
In the conditioned medium system sprouting could only clearly be induced by the Hs578T cell line. However, when tumor cell spheroids were present in the culture system the tumor cell lines were able to induce sprouting. This difference between media conditioned by tumor cell lines and tumor cell spheroids may be caused by the fact that some angiogenic factors produced by the tumor cells may have a short half-life. Only the conditioned medium of the most aggressive cell line (Hs578T) was able to induce clear sprouting, which suggests that induction of sprouting with conditioned medium is linked to the aggressiveness of the tumor ${ }^{21-24}$.

For the one well system in which the tumor cell spheroids are incorporated in the gel there are two options: spheroids can be grown in the gel, or they can be grown in medium and be transferred to a fresh gel just before the seeding of the endothelial cells on top of the gel. Surprisingly, when spheroids were grown in the gel, control BMEC showed sprouting and the differences between the various tumor cell lines were less clear. When instead experiments were carried out using a 'fresh' matrix (seeding of BMEC just after gelation of the gel) no sprouting was

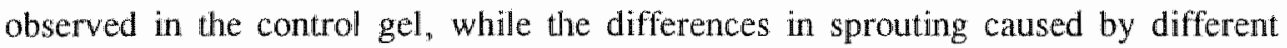
tumor cell lines were easy to evaluate. A possible explanation for this difference between the "old" and the "fresh" gell system can be a transformation of the collagen matrix occurring during the 24 days incubation at $37^{\circ} \mathrm{C}$ in the presence of $5 \%$ $\mathrm{CO}_{2}$ and culture media. As mentioned in the literature ${ }^{25}$ quantitative changes in matrix composition can influence cell survival and proliferation. It was not possible to study tumor biopsies in this one well system as the biopsies degraded the gel and grew out in a way that made identification of endothelial cell sprouting impossible. In order to circumvent the difficulties occurring when tumor biopsies were incorporated in the gel, a transwell model was used. Results obtained in this model were not consistent and we think that adsorption of factors from the medium to the insert/filter membrane could be responsible for this ${ }^{26}$.

Since we wanted to have a reliable, simple and rapid model we decided to use the conditioned medium system. In this system we are the first to demonstrate the dramatic anti-angiogenic effect of LBS-1 in an in vitro angiogenesis model. We demonstrate that this effect is explained by the downregulation of proliferation of endothelial cells. These observations are in line with earlier results found for angiostatin $^{16.27}$. Surprisingly, we found a strong inhibitory effect on in vitro angiogenesis at LBS-1 concentrations that did not significantly inhibit proliferation of endothelial cells. Either the in vitro angiogenesis model is a more sensitive assay system than measuring proliferation or the observed discrepancy demonstrates that inhibition of proliferation is not the only mechanism affected by LBS-1. This would imply that LBS-1 might be involved in the attenuation of growth factor receptor expression, the prevention of endothelial cell activation, the inhibition of endothelial cell migration or in the induction of apoptosis in the endothelial cells. We conclude that in vitro angiogenesis can be induced with conditioned media of 
some but not all tumor cell lines. The use of tumor cell spheroids incorporated in a collagen gel on which endothelial cells are seeded, can be attractive as a system for in vitro study. In addition we have shown using the conditioned medium system that anti-angiogenic activities can be demonstrated efficiently, indicating the value of this system for rapid and reliable screening of large numbers of, yet to be developed, angiogenesis inhibitors before testing in animal models or clinical settings. 


\section{References}

1. Folkman $\mathrm{J}$. What is the evidence that tumors are angiogenesis dependent? J Natl Cancer Inst 1990;82:4-6.

2. Folkman $J$. New perspectives in clinical oncology from angiogenesis research. Eur J Cancer 1996;32a:2534-2539.

3. Dvorak HF, Harvey VS, Estrella P, Brown LF, McDonagh J, Dvorak AM. Fibrin containing gels induce angiogenesis. Implications for tumor stroma generation and wound healing. Lab Invest 1987;57:673-686.

4. Leunig M, Yuan F, Menger MD, Boucher Y, Goetz AE, Messner K, Jain RK. Angiogenesis microvascular architecture, microhemodynamics, and interstitial fuid pressure during early growth of human adenocarcinoma LSI74T in SCID mice. Callicer Res 1992;52:6553-6560.

5. Lichenbeld HHC, Muller AD, Van Dam-Mieras MCE, Blijham GH. Tumor spheroid-induced vesicle formation on endothelial cells is associated with procoagulant propertics. J Cell Science 1993;106:657-662.

6. Montesano R. Regulation of angiogenesis in vitro. Eur J Clin Invest 1992;22: 504-515.

7. Huang $X$, Mollema $G$, King $S$, Watkins L, Edgington TS, Thorpe PE. Tumor infarction in mice by antibody-directed targeting of tissue factor to tumor vasculature. Science 1997:275:547-550.

8. Jain RK. Barriers to drug delivery in solid tumors. Scientific American $1994,271: 58-65$.

9. O'Reilly MS, Holmgren L, Shing Y, Chen C, Rosenthal RA, Moses M, Lane WS, Cao $Y$, Sage EH, Folkman J. Angiostatin: a novel angiogenesis inhibitor that mediates the suppression of metastases by a Lewis Lung carcinoma. Cell $1994 ; 79: 315-328$.

10. Cao Y, Ji RW, Davidson D, Schaller J, Marti D, Söhndal S, McCance SG, O"Reilly MS, Llinás M. Folkman d. Kringle domains of human angiostatin. Characterization of the anti-proliferative activity on endothelial cells. I Biol Chem 1996;271:29461-29467.

11. Kost C, Benner K, Stockmann A, Linder D, Preissner KT. Limited plasmin proteolysis of vitronectin. Characterization of the adhesion protein as morpho-regulatory and angiostatin-binding factor. Eur J Biochem 1996;236: 682-688.

12. Holmgren L, O'Reilly MS, Folkman J. Dormancy of micrometastases: balanced proliferation and apoptosis in the presence of angiogenesis suppression. Nat Med $1995 ; 1: 149-153$.

13. O'Reilly MS, Holmgren L, Chen C. Folkman J. Angiostatin induces and sustains dormancy of human primary tumors in mice. Nat Med 1996:2:689-692.

14. Carlsson J, Yuhas JM. Liquid-overlay culture of cellular spheroids. Recent Results. Cancer Res $1984: 95: 1-23$. 
15. Montesano R, Orci L, Vassalli P. In vitro organization of endothelial cells into capillary-like networks is promoted by collagen matrices. I Cell Biol 1983; $97: 1648-1652$.

16. Lowik CWGM, Alblas MJ, Van de Ruit M, Papapoulos SE, Van der Pluijm G. Quantification of adherent and nonadherent cells cultured in 96-well plates using the supravital stain neutral red. Anal Biochem 1993;213:426-433.

17. Olea N, Villalobos M, Ruiz de Almodóvar JM, Pedraza V. MCF-7 breast cancer cells grown as multicellular spheroids in vitro: effect of $17 \beta$-estradiol. Int 1 Cancer $1992 ; 50: 112 * 117$.

18. Barendsz-fanson AF, Muller AD, Lichtenbeld HHC, Van Dam-Mieras MCE. Hillen HFP. Cellular arrangement of human breast cancer cell lines determines hemostatic parameters. Tumor Biol 1998;19:104-112.

19. Lichtenbeld HHC, Van Dam-Mieras MCE, Hillen HFP. Tumor angiogenesis: pathophysiology and clinical significance. Neth J Med 1996;49:42-51.

20. Griffioen $\mathrm{AW}$, Damen $\mathrm{CA}$, Blijham $\mathrm{GH}$, Groenewegen $\mathrm{G}$. Tumor angiogenesis is accompanied by a decreased inflammatory response of tumor-associated endothelium. Blood 1996;88:667-673.

21. Engel LW, Young NA. Human breast carcinoma cells in continuous culture: A review. Cancer Res 1978;38:4327-4339.

22. Soule HD, Vazquez J, Long A, Albert S, Brennan M. A human cell line from a pleural effusion derived from a breast carcinoma. J Natl Cancer Inst 1973; $51: 1409-1416$.

23. Hackett AJ, Smith HS, Springer EL, Owens RB, Nelson-Rees WA, Riggs JL, Gardner MB. Two syngeneic cell lines from human breast tissue: the aneuploid mammary epithelial (Hs578T) and the diploid myoepithelial (Hs578Bst) cell lines. I Natl Cancer Inst 1977;58:1795-1806.

24. Tom BH, Rutzky LP, Jakstys MM, Oyasu R, Kaye CI, Kahan BD. Human colonic adenocarcinoma cells. Establishment and description of a new line. In Vitro 1976; 12:180-191.

25. Stadler E, Dziadek M. Extracellular matrix penetration by epithelial cells is influenced by quantitative changes in basement membrane components and growth factors. Exp Cell Res 1996;229:3601-369.

26. Sieuwerts AM, Klijn JGM, Foekens JA. Assessment of the invasive potential of human gynecological tumor cell lines with the in vitro Boyden chamber assay: influences of the ability of cells to migrate through the filter membrane. Clin Exp Metastasis 1997; 15:53-62.

27. Gately S, Twardowski P, Stack MS, Patrick M, Boggio L, Cundiff DL, Schnaper HW, Madison L, Volpert O, Bouck N, Enghild J, Kwaan HC, Soff GA. Human prostate carcinoma cells express enzymatic activity that converts human plasminogen to the angiogenesis inhibitor, angiostatin. Cancer Res 1996,56 : $4887 \times 4890$ 


\section{Chapter 5}

\section{In vitro effects of anti-tumor drugs on angiogenesis}

AF Barendsz-Janson, EAH Toebes, AW Griffioen, MCE van Dam-Mieras, HFP Hillen 


\section{Abstract}

Tumors are angiogenesis dependent and thus inhibition of angiogenesis could offer a novel type of cancer treatment. We have studied the anti-angiogenic effects and mechanisms of angiogenesis inhibition of the commonly used anti-tumor drugs tamoxifen, docetaxel and suramin. We measured the effects of these drugs on several endothelial cell types (bovine and human microvascular cells and human macrovascular cells) and tumor cell lines (Hs578T and T47D, both breast cancer cells, and LS174T colon cancer). Furthermore we compared their effects with those of the known angiogenesis inhibitors interferon- $\alpha$ (IFN $-\alpha), A G M-1470$ and marimastat. The drugs were tested in an in vitro angiogenesis model and the effects on proliferation (neutral red assay and ${ }^{3} \mathrm{H}$-thymidine incorporation) and apoptosis (morphology and subdiploid-peak FACS) were studied.

Docetaxel and tamoxifen were able to inhibit in vitro angiogenesis. Docetaxel induced apoptosis in all cell types. Tamoxifen induced a high rate of apoptosis in the tumor cells but only a slight increase in apoptosis was found in the endothelial cells. Suramin did not inhibit in vitro sprout formation, despite inhibition of proliferation and induction of apoptosis. IFN- $\alpha$ and marimastat, but not $\mathrm{AGM}-1470$, were found to inhibit tube formation efficiently. Marimastat did so without inhibition of proliferation and induction of apoptosis.

Evidence is presented that some anti tumor drugs directly inhibit angiogenesis by inhibition of proliferation and induction of apoptosis in endothelial cells. 


\section{Introduction}

Angiogenesis is required for tumor expansion beyond a size of $2 \mathrm{~mm}^{3}$ and for the formation of metastases ${ }^{1,2}$. The new vessels are necessary for the supply of nutrients and oxygen to the tumor cells. Inhibition of angiogenesis may, therefore, provide a novel form of cancer treatment. One of the problems in the treatment of cancer with conventional chemotherapy is acquired drug resistance. In endothelial cells (EC) drug resistance has been shown to be absent, probably because EC are genetically stable, homogenous and have a low mutational rate. Vessel directed therapy is also less dependent on the large biological variations found within tumors and on the variable accessibility of tumors and therefore could have a wide application.

Several anti-angiogenic mechanisms are known such as inhibition of EC growth e.g. by induction of apoptosis or blocking of vascular endothelial growth factor, blocking of cell adhesion processes and intervention in the degradation of matrix components. Some cytostatic compounds have been suggested to be antiangiogenic. For example tamoxifen inhibits angiogenesis by inhibiting EC proliferation ${ }^{4,5}$ and suramin by interfering with the binding of or signal transduction from growth factors ${ }^{6,7}$. In this paper the antiangiogenic potential and possible mechanism of angiogenesis inhibition are described for different anti-cancer drugs.

Firstly the anti-angiogenic effects of three tumor inhibiting drugs were tested in an in vitro angiogenesis assay. The results are compared with the effects of known angiogenesis inhibitors. Next, the possible mechanism of this inhibition was studied by measurement of proliferation and apoptosis of EC. The effect on tumor cell lines was also determined for these compounds. In this way the cytotoxic effect can be distinguished from a (possible) antiangiogenic effect. The anti-tumor drugs tested were suramin $^{7.8}$, docetaxel ${ }^{9}$ and tamoxifen ${ }^{4,5,10}$. The effects were compared with the effects of the angiogenesis inhibitors AGM-1470 (TNP-470) $)^{11,12}$, IFN- $\alpha^{13}$ and marimastat (BB2516) ${ }^{14}$. Evidence is presented that some anti-tumor drugs directly inhibit angiogenesis by inducing apoptosis in EC.

\section{Materials and methods}

\section{Cell cullture}

Bovine microvascular endothelial cells (BMEC), a kind gift from Dr. M. Furie (State University New York, Stony Brook, N.Y., USA), were routinely cultured on collagen (vitrogen-100, Collagen Corporation, Fermont, CA, USA) $(0.01 \%)$ coated tissue culture plastics (Costar, Cambridge UK) in $\alpha$-MEM (Life Technologies, Breda, The Netherlands) supplemented with donor calf serum (ICN, Zoetermeer, 
The Netherlands) and penicillin/streptomycin (50 IE/ml and $50 \mathrm{ng} / \mathrm{ml}$ respectively; ICN). Microvascular endothelial cells (MVEC) and human umbilical vein endothelial cells (HUVEC), isolated from the human foreskin and umbilical vein respectively, were cultured on collagen $(0.01 \%$ ) coated dishes in RPMI-1640 (Life Technologies) supplemented with 15\% FBS (Boehringer Ingelheim Biowhittaker, Verviers, Belgium), $15 \%$ human serum (Red Cross Blood Bank South-Limburg, Maastricht, the Netherlands), $2 \mathrm{mM}$ glutamine (ICN), $1.5 \mu \mathrm{g} / \mathrm{ml}$ endothelial cell growth supplement (Brunschwig Chemie), $5 \mathrm{IE} / \mathrm{ml}$ heparin (Leo Pharmaceutical Products, Weesp, The Netherlands) and penicillin/streptomycin $(50 \mathrm{IE} / \mathrm{ml}$ and $50 \mathrm{ng} / \mathrm{ml}$ respectively). Tumor cell lines (European Collection of Animal Type Cell Culture, ECACC, Salisbury, UK) T47D (breast carcinoma) and LS174T (colon carcinoma) were cultured in DMEM (Life Technologies) supplemented with $10 \%$ FBS and penicillin/streptomycin $(50 \mathrm{IE} / \mathrm{ml}$ and $50 \mathrm{ng} / \mathrm{ml}$ respectively). Hs578T (mammacarcinoma, ECACC) was cultured in DMEM with $4.5 \mathrm{~g} / 1$ glucose supplemented with $10 \%$ FBS, $2 \mathrm{mM}$ glutamine, $10 \mu \mathrm{g} / \mathrm{ml}$ insulin (Life Technologies) and penicillin/streptomycin (50 $\mathrm{IE} / \mathrm{ml}$ and $50 \mathrm{ng} / \mathrm{ml}$ respectively).

\section{Cytostatics and antiangiogenic drugs}

Suramin (germanin), kindly provided by Bayer (Mijdrecht, The Netherlands), was dissolved in water to a stock solution of $100 \mathrm{mg} / \mathrm{ml}$. Tamoxifen (Tocris Cookson, Ballwin, MO, USA) was dissolved in $90 \%$ ethanol in a stock solution of $1 \mathrm{mg} / \mathrm{ml}$. Docetaxel, a kind gift from Rhône-Poulenc Rorer (Amstelveen, The Netherlands), was dissolved in $95 \%$ ethanol (stock: $10 \mathrm{ng} / \mathrm{ml}$ ). IFN- $\alpha$ (Roferon- $\mathrm{A}$, obtained from Roche, Mijdrecht, The Netherlands) was dissolved in sterile bidest $(75000 \mathrm{IU} / \mathrm{ml})$. Marimastat (BB2516; kindly provided by British Biotech, Oxford, UK) and AGM-1470 (a kind gift from Takeda Industries Ltd., Osaka, Japan) were dissolved in DMSO (stock $1 \mathrm{mg} / \mathrm{ml}$ and $30 \mathrm{mg} / \mathrm{ml}$ respectively).

\section{Proliferation assays}

\section{Colorimetric determination of neutral red incorporation}

The neutral red assay was performed according to the method of Löwik et al. ${ }^{15}$. In short, cells were seeded in a 96 well plate ( 2500 cells/well) in the presence of the drugs in increasing concentrations; after 24 hours of culture neutral red (Sigma) was added. Cells were incubated for another 2 hours, washed, lysed and the optical density of the lysate was measured.

\section{Tritiated (PH)-thymidine incorporation}

Cell proliferation was measured using a $\left[{ }^{3} \mathrm{H}\right]$ thymidine incorporation assay ${ }^{16}$. Cells were seeded $\mathbb{1}: 10$ in flatbottomed tissue culture plates and grown for 72 hours, in the absence or presence of drugs. During the last 6 hours of the assay, the culture 
was pulsed with $0.5 \mu \mathrm{Ci}$ [methyl- ${ }^{3} \mathrm{H}$ ] thymidine/well. Activity was measured using liquid scintillation. Results are expressed as the arithmetic mean counts per minute of quadruplicate cultures.

\section{Apoptosis assay}

Apoptotic cells were determined according to the method of Relou ${ }^{17}$. Cells were cultured until confluence and incubated with different drugs. After 72 hours the cells were trypsinized, washed and fixed with $70 \%$ ethanol at $-20^{\circ} \mathrm{C}$ for at least 2 hours. Cells were centrifuged, resuspended in DNA extraction buffer $(90$ parts $0.05 \mathrm{M} \mathrm{Na}_{2} \mathrm{HPO}_{4}, 10$ parts $0.025 \mathrm{M}$ citric acid and 1 part $10 \%$ Triton X-100) for 20 minutes at $37^{\circ} \mathrm{C}$ whereafter propidium iodide (final concentration $0.05 \mathrm{mg} / \mathrm{ml}$; Calbiochem, Omnilabo, Breda, The Netherlands ) was addled. Stained cells were analyzed on a FACScan flow cytometer (FACSCaliber, Becton Dickinson). Of each sample, forward scatter (FSC), side scatter (SSC) and red fluorescence $(642 / 20 \mathrm{~nm})$ signals of 3000 cells were recorded. The apoptotic cells (subdiploidpeak) and proliferative fraction ( 4 n-DNA peak) can be determined using cell-quest software.

\section{In vitro angiogenesis}

The in vitro angiogenesis assay was performed as described previously ${ }^{18}$. Briefly, BMEC were seeded on top of a semi-natural collagen matrix (mixing 8 volumes vitrogen-100 with $\mathbb{1}$ volume $10 \mathrm{x}$ concentrated $\alpha$-MEM and 1 volume sodium bicarbonate $-11.76 \mathrm{mg} / \mathrm{ml}$-) and allowed to grow to a confluent monolayer. At this time point the drugs were added and the cells were cultured further for 24 hours. To induce sprouting in this model $25 \mathrm{ng} / \mathrm{ml}$ basic fibroblast growth factor (bFGF) was added. After another 24 and 48 hours of culture the (sprouting) monolayers were photographed with a Zeiss inverted phase-contrast photomicroscope. The amount of sprouting was quantified by the computer program NIH image 1.58 . Cells cultured with bFGF only were used as positive control (set on 100\%).

Statistical significance of differences was tested by the student's t-test.

\section{Results}

A number of anti-cancer drugs are claimed to exert anti-angiogenic effects. Among them are docetaxel, tamoxifen and suramin. To investigate the impact of these anticancer drugs on angiogenesis, their effects on in vitro tube formation was studied and compared with that of a number of well known inhibitors of angiogenesis. A comparison of the influence of the drugs on in vitro sprout formation of BMEC was made. In this model system ${ }^{19}$ sprout formation was induced by bFGF. For all 
drugs concentrations demonstrated to be effective in vitro were used ${ }^{7,9,12.14,20.21}$. Figure 5.1 panel A demonstrates the culture without bFGF. Panel B shows the bFGF induced sprout formation and $C$ and $D$ illustrate the inhibition of bFGF induced sprout formation by docetaxel and IFN- $\alpha$ respectively. Figure 5.1E quantifies the effects of all agents tested. It is demonstrated that all agents except AGM-1470 and suramin inhibit in vitro angiogenesis. Docetaxel was able to block new vessel formation completely which has also been found for angiostatin ${ }^{19}$. IFN- $\alpha$, tamoxifen and marimastat inhibited angiogenesis by approximately $50 \%$.
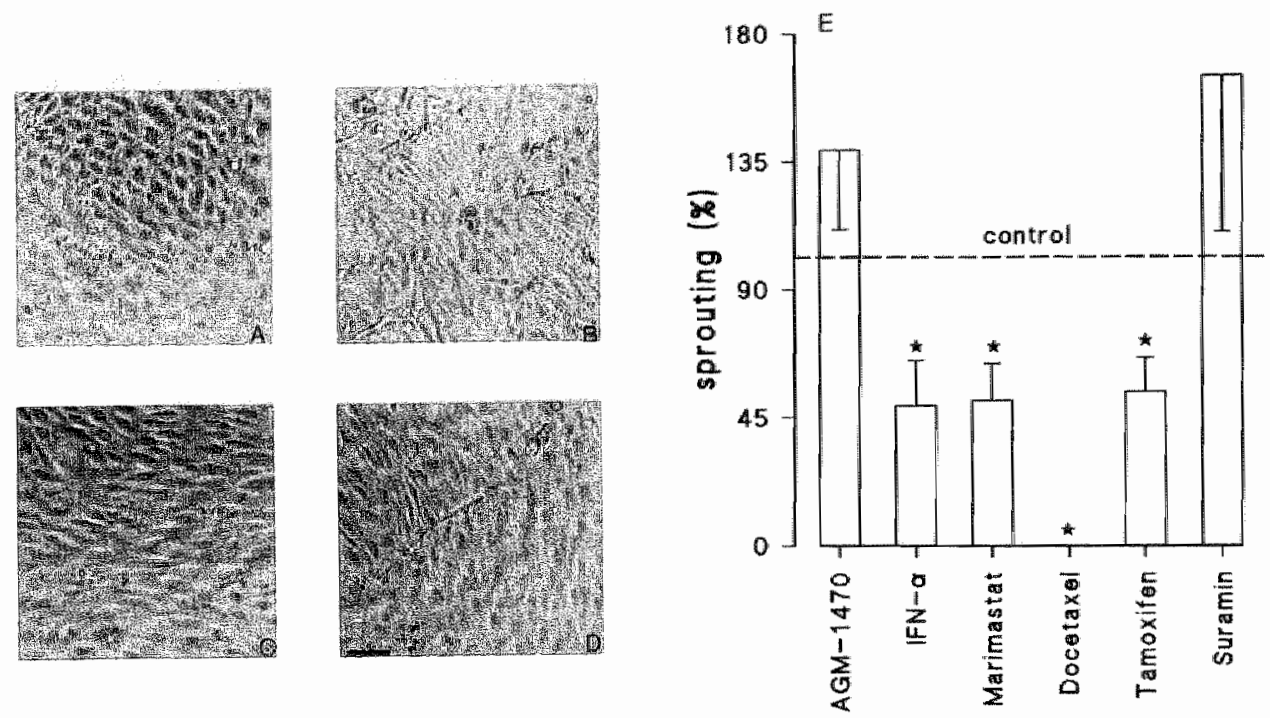

Figure 5.1 In vitro angiogenesis of BMEC cultured in the absence or presence of drugs. Cells were cultured without bFGF (A), with $25 \mathrm{ng} / \mathrm{ml}$ bFGF (B) with $25 \mathrm{ng} / \mathrm{ml}$ bFGF and $3 \mathrm{ng} / \mathrm{ml}$ docetaxel (C) or with $25 \mathrm{ng} / \mathrm{ml}$ bFGF and $4500 \| \mathrm{U} / \mathrm{ml}$ IFN-cx (D). Scals bar is $50 \mu \mathrm{m}$. Panel E shows the percentages of sprouting compared to control ( $=100 \%$ ) of BMEC. Sprouting is induced by $25 \mathrm{ng} / \mathrm{ml}$ bFGF. Results are shown as mean \pm sem (at least $n=4, *=p<0.05$ ).

To unravel the mechanism behind the inhibition of angiogenesis the effects of the known angiogenesis inhibitors on cell proliferation and apoptosis were studied. The effect of the drugs on proliferation and apoptosis of three human cancer cell lines was measured and compared with the effects on proliferation and apoptosis of EC under the same conditions. Table 5.1 shows the results from proliferation measurements with the neutral red assay for the anti-endothelial drugs on all cells. Similar results were found when proliferation was studied by ${ }^{3} \mathrm{H}$-thymidine incorporation (data not shown). For apoptosis measurement the highest 
concentration utilized in the proliferation assays was used. The results of the apoptosis assay and proliferation assay are summarized in table 5.1 .

We found that AGM-1470 was able to inhibit proliferation of $\mathrm{EC}$ strongly while the effect on tumor cells was less. The increase in apoptosis induced by AGM-1470 was also stronger in EC than in tumor cells. For IFN- $\alpha$ the results were diverse. Only the bovine cell proliferation was inhibited for the EC. Apoptosis was induced in LS174T and Hs578T cells and proliferation inhibited in the Hs578T cells. Marimastat inhibited the human EC proliferation but not the BMEC proliferation. Apoptosis induction was limited in the human EC and completely absent in the BMEC. Tumor cell proliferation was inhibited by marimastat and apoptosis was induced in all tumor types although clear differences could be found in the effects between the three different tumor cell lines studied.

Table 5.1 Cells incubated with known angiogenesis inhibitors (AGM-1470 (I ng/ml), IFN- $\alpha(4500 \mathrm{lU} / \mathrm{ml})$ and marimastat $(10 \mu \mathrm{g} / \mathrm{ml}))$. Results are shown as mean percentages $\pm \operatorname{sem}(n=4$ at least).

\begin{tabular}{|c|c|c|c|c|c|}
\hline & & control & AGM-1470 & IFN- $a$ & marimastat \\
\hline \multirow[t]{2}{*}{$\mathrm{BMEC}$} & proliferation & 100 & $43 \pm 3$ & $78 \pm 3$ & $95 \pm 5$ \\
\hline & apoptosis & $0.9 \pm 0.3$ & $5.8 \pm 3.3$ & $1.1 \pm 0.5$ & $0.7 \pm 0.2$ \\
\hline \multirow[t]{2}{*}{ MVEC } & proliferation & 100 & $72 \pm 4$ & $148 \pm 10$ & $71 \pm 5$ \\
\hline & apoptosis & $2.4 \pm 1$ & $5.1 \pm 2$ & $4 \pm 1.7$ & $3.8 \pm 0.9$ \\
\hline \multirow[t]{2}{*}{ HUVEC } & proliferation & 100 & $63 \pm 1$ & $116 \pm 12$ & $65 \pm 8$ \\
\hline & apoptosis & $2.1 \pm 0.4$ & $6.2 \pm 1.5$ & $2.9 \pm 0.4$ & $3.9 \pm 2.2$ \\
\hline \multirow[t]{2}{*}{$\mathrm{T} 47 \mathrm{D}$} & proliferation & 100 & $93 \pm 3$ & $107 \pm 3$ & $44 \pm 4$ \\
\hline & apoptosis & $2.8 \pm 0.5$ & $2.2 \pm 0.6$ & $1.9 \pm 0.1$ & $7.2 \pm 3.2$ \\
\hline \multirow[t]{2}{*}{$\mathrm{Hs} 578 \mathrm{~T}$} & proliferation & 100 & $81 \pm 3$ & $26 \pm 1$ & $85 \pm 10$ \\
\hline & apopiosis & $5.4 \pm 0.8$ & $6.8 \pm 0.6$ & $11.9 \pm 1.2$ & $9.3 \pm 0.5$ \\
\hline \multirow[t]{2}{*}{$\mathrm{LSI} 174 \mathrm{~T}$} & proliferation. & 100 & $85 \pm 4$ & $108 \pm 15$ & $54 \pm 8$ \\
\hline & apoptosis & $2.8 \pm 0.8$ & $3.5 \pm 2.1$ & $11.2 \pm 5.8$ & $12.4+6.4$ \\
\hline
\end{tabular}

The same experiments were performed for both umor cells and EC using cytostatics. Dose-response range experiments were performed for all cell lines. Figure 5.2 shows an example of the proliferation of a tumor cell line and of EC cultured in the presence of docetaxel. Both cell types were inhibited significantly at a concentration of $3 \mathrm{ng} / \mathrm{ml}$. 


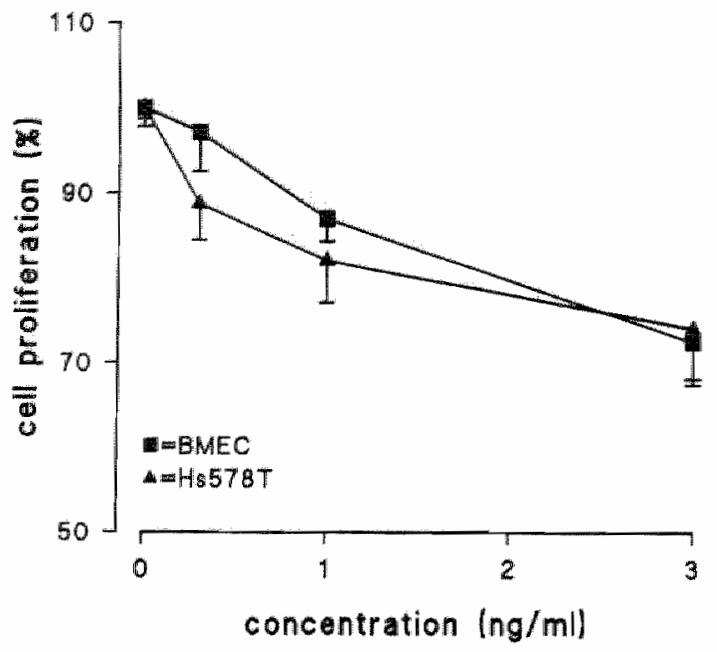

Figure 5.2 Cell viability determined by a neutral red assay for BMEC and Hs578T cultured in the presence of different concentrations of docetaxel. Results are given as mean percentage ( \pm sem) of the control cells $(n=6)$.

Figure 5.3 shows an example of apoptosis induction in the tumor cell line Hs578T and HUVEC incubated with the different drugs. The tumor cell line was shown to be more sensitive for apoptosis induction by the different drugs than the EC.
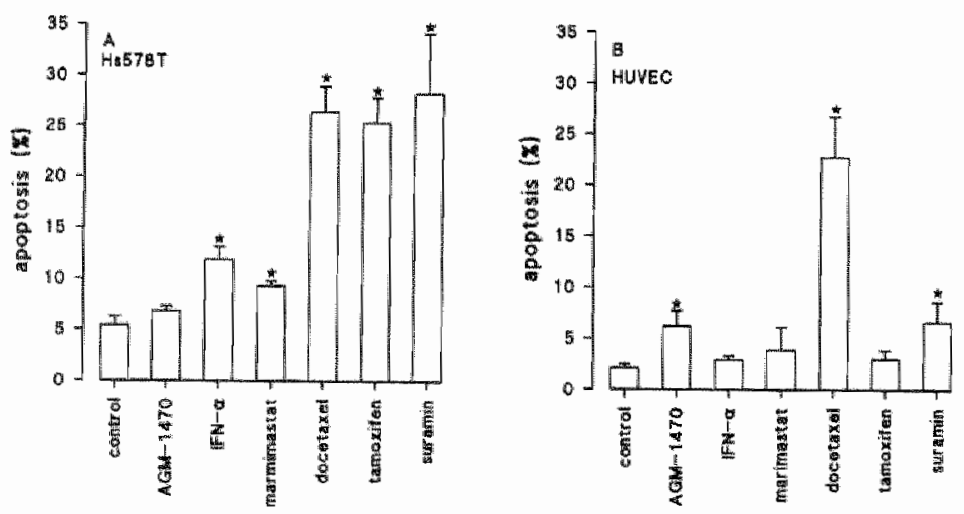

Figure 5.3 Induction of apoptosis in the cells Hs578T (A) and HUVEC (B) by the drugs AGM- 1470 (1 $\mathrm{ng} / \mathrm{ml})$, IFN- $\alpha(4500 \mathrm{IU} / \mathrm{ml})$, marimastat $(10 \mu \mathrm{g} / \mathrm{ml})$, docetaxel $(3 \mathrm{mg} / \mathrm{ml})$, tamoxiten $(10 \mu \mathrm{g} / \mathrm{ml})$ and suramin $(500 \mu \mathrm{g} / \mathrm{ml})$. Results were retrieved by the measurement of the sub-diploid DNA peak after propidium iodide staining and presented as percentage of total anount of cells. $(n=4, *=p<0.05)$. 
The results of the incubation of all cells with the anti tumor drugs (summarized in table 5.2) showed that docetaxel was able to inhibit cell proliferation of microvascular EC. In Hs578T and LS174T cell proliferation was also inhibited. Apoptosis was increased in all cell types by docetaxel although the increase of apoptosis in the microvascular cells was much lower than that in the macrovascular $\mathrm{EC}$ and in the tumor cells. Tamoxifen was able to increase apoptosis and inhibit proliferation in all cell types. The drug suramin, currently used in phase 1/II trails, markedly inhibited proliferation of tumor cells. It was also the most effective inhibitor of EC proliferation. Next to its proliferation inhibiting capacity, it was able to induce apoptosis in tumor cells as well as in EC although the effect of apoptosis induction in BMEC was very limited.

Table 5.2 Cells incubated with tumor-inhibiting drugs (docetaxel $(3 \mathrm{ng} / \mathrm{ml}$ ), tamoxifen $(10 \mu \mathrm{g} / \mathrm{ml})$ and suramin $(500 \mu \mathrm{g} / \mathrm{mll}))$. Results are shown as mean percentages $\pm \operatorname{sem}(n=4$ at least).

\begin{tabular}{|c|c|c|c|c|c|}
\hline & & control & docetaxel & tamoxifen & suramin \\
\hline \multirow[t]{2}{*}{ BMEC } & proliferation & 100 & $72 \pm 5$ & $34 \pm 8$ & $33 \pm 2$ \\
\hline & apoptosis & $0.9 \pm 0.3$ & $2.7 \pm 1.2$ & $2.6 \pm 1$ & $1.6 \pm 0.4$ \\
\hline \multirow[t]{2}{*}{ MVEC } & proliferation & 100 & $74 \pm 4$ & $76 \pm 8$ & $43 \pm 1$ \\
\hline & apoptosis & $2.4 \pm 1$ & $8.4 \pm 1.1$ & $6.3 \pm 4.1$ & $6.5 \pm 1.8$ \\
\hline \multirow[t]{2}{*}{ HUVEC } & proliferation & 100 & $91 \pm 5$ & $81 \pm 8$ & $61 \pm 2$ \\
\hline & apoptosis & $2.1 \pm 0.4$ & $22.7 \pm 4$ & $3 \pm 0.9$ & $6.6 \pm 2$ \\
\hline \multirow[t]{2}{*}{$\mathrm{T} 47 \mathrm{D}$} & proliferation & 100 & $95 \pm 3$ & $25 \pm 3$ & $29 \pm 3$ \\
\hline & apoptosis & $2.8 \pm 0.5$ & $29.5 \pm 3.4$ & $12.7 \pm 4.3$ & $9.4 \pm 3.5$ \\
\hline \multirow[t]{2}{*}{$\mathrm{Hs} 578 \mathrm{~T}$} & proliferation & 100 & $74 \pm 6$ & $68 \pm 11$ & $4 \pm 1$ \\
\hline & apoptosis & $5.4 \pm 0.8$ & $26.4 \pm 2.5$ & $25.3 \pm 2.5$ & $28.2 \pm 5.9$ \\
\hline \multirow[t]{2}{*}{$\mathrm{LS} / 74 \mathrm{~T}$} & proliferation & 100 & $72 \pm 10$ & $45 \pm 6$ & $4 \pm 1$ \\
\hline & apoptosis & $2.8 \pm 0.8$ & $22.6 \pm 7.2$ & $24.8 \pm 6.7$ & $29.1 \pm 7.2$ \\
\hline
\end{tabular}

Table 5.3 gives an overview of all results. In general the effects of the knownangiogenesis inhibitors were stronger on $\mathrm{EC}$ whereas the effects of the anti-tumor drugs were stronger on the tumor cells. 
Table 5.3 Overview all results. $A=$ apoptosis; $P=$ proliferation; $S=$ in vitro angiogenesis $\Downarrow=$ decreased compared to control $(p<0.05)$. $\Uparrow=$ increased compared to control $(p<0.05)$. * increased compared to control, but not significantly. - = no difference with control.

\begin{tabular}{|c|c|c|c|c|c|c|c|c|c|c|c|c|c|}
\hline & \multicolumn{3}{|c|}{ BMEC } & \multicolumn{2}{|c|}{ MVEC } & \multicolumn{2}{|c|}{ HUWEC } & \multicolumn{2}{|c|}{ T47D } & \multicolumn{2}{|c|}{ Hs578T } & \multicolumn{2}{|c|}{ LS174T } \\
\hline & $\mathrm{p}$ & A & S & P & A & $\mathrm{P}$ & A & $\mathrm{P}$ & A & $\mathrm{P}$ & A & $\mathrm{P}$ & A \\
\hline $\begin{array}{l}\mathrm{AGM}-1470 \\
1 \mathrm{ng} / \mathrm{ml}\end{array}$ & 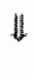 & $\uparrow$ & 1 & $\Downarrow$ & $\uparrow$ & $\mathbb{1}$ & $\pi$ & - & - & $u$ & " & $\Downarrow$ & - \\
\hline $\begin{array}{l}\text { IFN- } \\
45000 / \mathrm{ml}\end{array}$ & $\|$ & - & ॥ & $\Uparrow$ & $\uparrow$ & - & $\uparrow$ & - & - & $\mathbb{U}$ & $\Uparrow$ & - & $\uparrow$ \\
\hline $\begin{array}{l}\text { marimastat } \\
10 \mu \mathrm{kg} / \mathrm{mal}\end{array}$ & - & - & $\Downarrow$ & 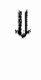 & $\uparrow$ & $\Downarrow$ & - & $\Downarrow$ & $\uparrow$ & - & $\Uparrow$ & 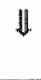 & $\uparrow$ \\
\hline $\begin{array}{l}\text { docetaxel } \\
\text { 3ng/m! }\end{array}$ & $\Downarrow$ & $\uparrow$ & $\Downarrow$ & $\Downarrow$ & $\uparrow$ & - & $\Uparrow$ & - & $\mathbb{\pi}$ & Ut & $\Uparrow$ & $\Downarrow$ & ft \\
\hline $\begin{array}{l}\text { tamoxifen } \\
10 \mu \mathrm{gg} / \mathrm{ml}\end{array}$ & $\|$ & 1 & $\|$ & $\|$ & $\uparrow$ & - & $\uparrow$ & $\|$ & $\Uparrow$ & $\Downarrow$ & $\Uparrow$ & $\Downarrow$ & $\Uparrow$ \\
\hline $\begin{array}{l}\text { suramin } \\
500 \mathrm{pg} / \mathrm{ml} l\end{array}$ & $\Downarrow$ & $\uparrow$ & $\uparrow$ & U & $\pi$ & $\Downarrow$ & $\Uparrow$ & $\|$ & $\Uparrow$ & $\Downarrow$ & $\Uparrow$ & $\Downarrow$ & $\Uparrow$ \\
\hline
\end{tabular}

\section{Discussion}

Angiogenesis is a complex process, which is essential for tumor expansion and metastasis. Interference with the angiogenic process is, therefore, an attractive strategy in tumor therapy. Next to the recently described specific inhibitors of angiogenesis, such as angiostatin and endostatin, a number of anti-cancer drugs may have an inhibitary effect on the formation of new vessels. The presence of an angiostatic component in the mechanism of action of an anti-cancer drug may have implications for the dose and duration of administration.

Here we present data that demonstrate that the anti-cancer drugs docetaxel and tamoxifen display an inhibitory effect on angiogenesis in vitro. In addition, the mechanism behind this effect is the induction of apoptosis and the inhibition of proliteration in endotheliall cells.

Docetaxel is shown to be a very efficient inhibitor of in vitro bFGF induced angiogenesis, leading to a complete blockade of tube formation. The effect is largely explained by the inhibition of proliferation in EC since a rather low level of apoptosis induction was observed. The mechanism of docetaxel (taxotere) is the stabilization of microtubules and the inhibition of their depolymerization to free tubulin. It might be expected that these effects in vitro cause the inhibition of endothelial cell replication and subsequent angiogenesis 9 .

The antiestrogen tamoxifen ${ }^{4,10}$ is able to inhibit in vitro angiogenesis by 
approximately $55 \%$. This significant inhibition of tube formation is mainly explained by inhibition of proliferation. The percentage of EC undergoing apoptosis, although showing an increased trend, was not significantly upregulated by exposure to tamoxifen.

For suramin, a polysulphonated urea which binds to growth factors such as bFGF $F^{6,8}$, we did not find inhibition of in vitro tube formation. In contrast, we did find inhibition of EC growth and a moderate induction of apoptosis in these cells. Earlier studies reported a dual effect of suramin on in vitro EC sprouting. It was reported $^{22}$ that EC growth was inhibited by suramin but tube formation was even stimulated at a concentration of $100 \mu \mathrm{M}$, while it was inhibited at $300 \mu \mathrm{M}$ with no effect being observed at concentrations of less than $30 \mu \mathrm{M}$. An explanation for the discrepancies between proliferation, apoptosis and tube formation could be sought in the interaction of the drug with matrix components. Proliferation and apoptosis were measured on cells cultured on a collagen coat (two-dimensional). In contrast, in the in vitro angiogenesis assay the cells were cultured on a thick collagen gel in which the cells were able to sprout (three-dimensional). Recently, it has been published ${ }^{23}$ that large differences in the expression of matrix metalloproteinases are found between cells cultured on a two-dimensional collagen coat (proliferation) and those on a three-dimensional collagen matrix (tube formation). Such differences can be caused by ligand-specific and mechanical force-sensitive components.

The effects of the anti-cancer drugs on angiogenesis, were compared with those of well-known angiogensis inhibitors. IFN- $\alpha$, which is used as therapy for lifethreatening hemangiomas of infancy ${ }^{13}$, was able to inhibit in vitro angiogenesis by $51 \%$. How angiogenesis is inhibited is not clear because the effect on BMEC proliferation is limited and apoptosis is not increased at all. These results are in agreement with the results found by Lebbe et al. who described that the inhibiting effect of IFN- $\alpha$ was not a direct effect on endothelial cell proliferation ${ }^{24}$. MVEC proliferation seemed to be stimulated rather than inhiljited by IFN- $\alpha$. We, and others, found that IFN- $\alpha$ can increase EC growth, which may be due to an enhancement in endogenous bFGF synthesis and release ${ }^{22}$. That the effect of IFN $-\alpha$ in vitro is not simple and straightforward is also mentioned by Auerbach who described that IFN- $\alpha$ is able to potentiate the angiogenic effect of interleukin- 2 in addition to its inhibitory effect on angiogenesis ${ }^{23}$. Marimastat, a synthetic peptide which inhibits metalloproteinase activity ${ }^{14}$ was able to inhibit in vitro angiogenesis. Because metalloproteinases are important for EC to invade the extracelluiar matrix $^{25}$, we expected to find inhibition of in vitro angiogenesis by marimastat. BMEC proliferation and apoptosis were not influenced by marimastat although marimastat was able to inhibit cell proliferation and to induce apoptosis (T47D and LS $174 \mathrm{~T}$ ). So the sprouting inhibition by marimastat was not due to proliferation inhibition or apoptosis induction but probably due to lack of capability of the cells 
to degrade the matrix.

AGM-1470 (TNP-470), a synthetic analog of the antibiotic fumagillin ${ }^{27}$ is an angiogenesis inhibitor which has been shown to inhibit EC (HUVEC) proliferation by preventing the entry of cells into the G1-phase of the cell cycle ${ }^{28}$. In the experiments described here, AGM-1470 was able to inhibit EC proliferation at concentrations of $1 \mathrm{ng} / \mathrm{ml}$ as shown by others ${ }^{12}$. However, the in vitro angiogenesis of BMEC was not inhibited by AGM-1470 as found by others for in vitro angiogenesis with HUVEC ${ }^{29}$. The reason why AGM-1470 was not able to inhibit in vitro angiogenesis, while inhibiting proliferation and also increasing apoptosis, is not clear. One explanation for this observation could be that AGM-1470 is less effective on a confluent layer of cells (as used in the angiogenesis assay) than on a sub-confluent layer (as used in the proliferation and apoptosis assay). Alternatively, the matrix and the configuration of the matrix on which the cells are cultured may have an impact on the characteristics of $\mathrm{EC}^{18.23}$. It could be that the collagen matrix (two dimensional in the proliferation and apoptosis assay and three dimensional in the angiogenesis assay) determines the net effect of the drugs. Another explanation for the discrepancy of the results could be that only a small minority of the cells will sprout upon stimulation with bFGF, while proliferation and apoptosis are measured in all cells. Our results demonstrate, not unexpectedly, that in vitro assay systems are valuable for testing specific steps in the whole cascade of reactions leading to in vivo angiogenesis. Of course systemic effects can not be measured in in vitro model systems and therefore, in vivo demonstration of effectiveness will be necessary to validate clinical use of drugs.

Due to the lack of drug resistance, anti-angiogenic therapy is an attractive target for cancer therapy. The present results demonstrate that anti-cancer drugs, next to a direct inhibitory effect on proliferation of tumor cells, can inhibit angiogenesis. It remains to be investigated whether the beneficial effects of these drugs in the control of cancer depends (at least partly) on this angiogenesis inhibition. In that case it could be anticipated that low dose administration for a prolonged period might be the optimal treatment strategy. 


\section{References}

1. Folkman J. Tumor angiogenesis: therapeutic implications. New Engl J Med 1971; 285: $1182-1186$

2. Folkman J. What is the evidence that tumors are angiogenesis dependent? I Natl Cancer Inst 1990;82:4-6.

3. Boehm T, Folkman J, Browder T, O'Reilly MS. Antiangiogenic therapy of experimental cancer does not induce acquired drug resistance. Nature 1997; 390:404-407.

4. Chen H, Tritton TR, Kenny N, Absher M, Chiu J-C. Tamoxifen induces TGF- $\beta 1$ activity and apoptosis of human MCF-7 breast cancer cells in vitro. $\mathbb{N}$ Cell Biochem 1996;61:9-17.

5. Gasparini G. Angiogenesis research up to 1996. A commentary on the state of art and suggestions for future studies. Eur J Cancer 1996;32a:2379-2385.

6. Pesenti E, Sola F, Mongelli N, Grandi M, Spreafico F. Suramin prevents neovascularisation and tumour growth through blocking of basic fibroblast growth factor activity. Br J Cancer 1992;66:367-372.

7. Braddock PS, Hu D-E, Fan T-PD, Stratford IJ, Harris AL, Bicknell R. A structure-activity amalysis of antagonism of the growth factor and angiogenic activity of basic fibroblast growth factor by suramin and related polyanions. Br $J$ Cancer 1994;69:890-898.

8. Morris $A D$, Léonce $S$, Guilbaud N, Tucker GC, Pérez V, Jan M, Cordi AA, Pierré A, Atassi G. Eriochrome Black $T$, structurally related to suramin inhibits angiogenesis and tumor growth in vivo. Anti-Cancer Drugs 1997;8:746-755.

9. Zoli W, Flamigni A, Frassineti GL, Bajorko P, DePaola F, Milandri C, Amadori D, Gasperi-Campani A. In vitro activity of taxol and taxotere in comparison with doxorubicin and cisplatin on primary cell cultures of human breast cancers. Breast Cancer Res Treat 1995;34:63-69.

10. Chalbos D, Vignon F, Keydar I, Rochefort H. Estrogens stimulate cell proliferation and induce secretory proteins in a human breast cancer cell tine (T47D). I Clin Endocrinol Metab 1982;55:276-283.

11. Antoine N, Daukandt M, Heinen E, Simar LJ, Castronovo V. In vitro and in vivo stimulation of the murine immune system by $\mathrm{AGM}-1470$, a potent angiogenesis inhibitor. Am J Pathol 1996;148:393-398.

12. Maier JAM, Delia D, Thorpe PE, Gasparini G. In vitro inlibition of endothelial cell growth by the antiangiogenic drug AGM-1470 (TNP-470) and the anti-endoglin antibody TEC-11. Anti-Cancer Drugs 1997:8:238-244.

13. Ezekowitz RAB, Mulliken JB, Folkman J. Interferon alfa-2a therapy for life-threatening hemangiomas of infancy. New Engl J Med 1992;326:1456-1463.

14. Rasmussen HS, McCann PP. Matrix metalloproteinase inhibition as a novel anticancer strategy: a review with special focus on batimastat and marimastat. Pharmacol Ther 1997;75:69-75. 
15. Lowik CWGM, Alblas MJ, Van de Ruit M, Papapoulos SE, Van der Pluijm G. Quantification of adherent and nonadherent cells cultured in 96-well plates using the supravital stain neutral red. Anal Biochem 1993;213:426-433.

16. Griffioen AW, Coenen MJH, Damen CA, Hellwig SMM, Van Weering DHJ, Vooys W, Bliham GH, Groenewegen G. CD44 is involved in tumor angiogensis; an activation antigen on human endothelial cells. Blood 1997;90:1150-1159.

17. Relou IAM, Damen CA, van der Schaft DWJ, Groenewegen GG, Griffioen AW. Effect of culture conditions on endothelial cell growth and responsiveness. Tissue \& Cell 1998;in press.

18. Barendsz-Janson $\mathrm{AF}_{\text {, }}$ Muller $\mathrm{AD}$, Lichtenbeld HHC, Van Dam-Mieras MCE , Hillen HFP. Cellular arrangement of human breast cancer cell lines determines hemostatic parameters. Tumor Biol 1998;19:104-112.

19. Barendsz-Janson AF, Griffioen AW, Muller AD, Van Dam-Mieras MCE, Hillen HFP. In vitro tumor angiogenesis assays: plasminogen lysine binding site 1 inhibits in vitro tumor induced angiogenesis. J Vasc Res 1998;35:109-114.

20. Majewski S, Marczak M, Szmurlo A, Jablonska S, Bollag W. Retinoids, interferon $\alpha, 1,25$-dihydroxyvicamin $D_{3}$ and their combination inhbit angiogenesis induced by non-HPV-harboring tumor cell lines. RARo mediates the antiangiogenic effects of retinoids. Cancer Lett 1995;89:117-124.

21. Kang $Y$, Cortina $R$, Perry RR. Role of c-myc in tamoxifen-induced apoptosis in estrogen-independent breast cancer cells. J Natl Cancer Inst 1996;88:279-284.

22. Pepper MS, Vassalli J-D, Wilks JW, Schweigerer L, Orci L, Montesano $R$. Modulation of bovine microvascular endothelial cell proteolytic properties by inhibitors of angiogenesis. J Cell Biochem 1994;55:419-434.

23. Haas TL, Davis SJ, Madri JA. Three-dimensional type I collagen lattices induce coordinate expression of matrix metalloproteimases MT1-MMP and MMP-2 in microvascular endothelial cells. J Biol Chem 1998;273:3604-3610.

24. Lebbe C, DeCremoux $\mathbb{P}$, Millot G, Podgorniak MP, Verola $O$, Berger $R$, Morel $P$, Calvo F. Characterization of in vitro culture of HIV-negative Kaposi's sarcoma-derived cells. In vitro responses to alpha interferon. Arch Dermatol Res $1997 ; 289: 421-428$.

25. Auerbach W, Auerbach R. Angiogenesis inhibition: a review. Pharmac Ther 1994; 63:265-311.

26. Fisher $\mathrm{C}$, Gilbertson-Beadling $\mathrm{S}$, Powers EA, Petzold $\mathrm{G}_{\text {, }}$ Poorman $\mathrm{R}$, Mitchell MA. Interstitial collagenase is required for angiogenesis in vitro. Dev Biol 1994; $162: 499-510$.

27. Parangi $S$, O'Reilly $M$, Christofori $G$, Holmgren L, Grosfeld J, Folkman J, Hanahan D. Antiangiogenic therapy of transgenic mice impairs de novo tumor growth. Proc Nail Acad Sci USA 1996:93:2002-2007.

28. Almed MH, Arai 'T, Konno $H$, Nahar L, Tanaka T, Izumiyama $N$, Takubo $\mathbb{K}$, Nakamura $S$. Baba $S$. Regression of metastatic liver tumors in rats treated with angiogenesis inhibitor TNP-470; occurence of apoptosis and necrosis. Ipn J Cancer Res 1997:88:977.981. 
29. Antoine N, Greimers R, De Roame C, Kusaka M, Heinen E, Simar LI, Castronovo V. AGM-1470, a potent angiogenesis inhibitor, prevents the entry of normal but not transformed endothelial cells into the G1 phase of the cell cycle. Cancer Res 1994: $54: 2073-2076$. 


\section{Chapter 6}

\section{Apoptosis induction and anti- proliferative effects of suramin and its analog suradista}

AF Barendsz-Janson, EAH Toebes, HFP Hillen, MCE van Dam-Mieras, AW Griffioen 


\begin{abstract}
Suramin is an effective antineoplastic drug but the therapeutic range between effective tumor inhibition and severe toxicity is very narrow. Suradista, an analog of suramin, was developed in an attempt to make a less toxic drug with the same antineoplastic effect. In this paper both compounds are compared for their effects on tumor cell and endothelial cell proliferation, on apoptosis and in an in vitro angiogenesis assay.

The results of the proliferation assays showed that both compounds were able to inhibit cell proliferation. The effect of both inhibitors was stronger on tumor cells than on endotheial cells and was much stronger in the cultures in which the cells were not allowed to adhere before suramin or suradista was added. Apoptosis could be induced in all 6 cell types by both suramin and suradista; however suradista was more effective than suramin. In the in vitro angiogenesis assay, no differences between the effects induced by the two compounds could be found. We can conclude that suradista is more effective than suramin in inhibiting tumor cells in vitro and is less cytotoxic to endothelial cells.
\end{abstract}




\section{Introduction}

Suramin is a polysulfonated naphthylurea, first synthesized in 1917. In 1924 it was first used in the treatment of protozoal infections (trypanosomiasis and onchocerciasis). Nowadays, its efficacy is proven in clinical trials for advanced cancers of prostate, kidney, adrenal glands, ovary and in lymphomas. The mechanism of the antitumor action of suramin is complex. It is able to inhibit protein kinase $\mathrm{C}$, heparanase, DNA topoisomerase and interleukin $\mathrm{I}^{1.2}$. Because many factors involved in angiogenesis are affected by suramin, the antineoplastic effect of suramin could also, at least partly, be due to angiogenesis inhibition. For instance, suramin inhibits the binding of growth factors, such as PDGF, EGF, TGF- $\beta$, FGF and VEGF, to their receptors. Suramin decreases cell invasion through the basement membrane, endothelial cell proliferation and the urokinasetype plasminogen activator activity of endothelial cells. The compound was shown to be anti-angiogenic in the chick chorioallantoic membrane assay ${ }^{1-5}$.

One of the major problems of suramin in clinical use is the narrow therapeutic range between the dose which is required for an effective tumor inhibition and the dose leading to severe toxicity. For that reason an analog of suramin with similar anti-tumor activity but substantially lower toxicity would be very valuable. Some analogs are already being tested ${ }^{1.6}$. In the present study the effectiveness of suradista, a derivative of distamycin $\mathrm{A}$ and analog of suramin, is compared to that of suramin (both structures are given in figure 6.1).

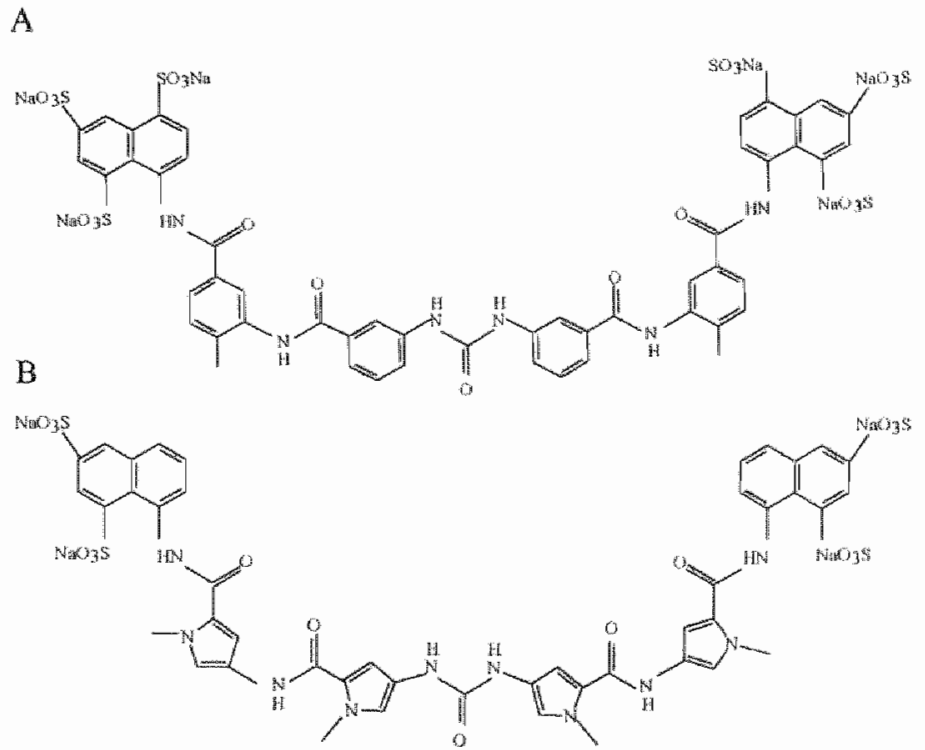

Figure 6.1 Structural formula of suramin (A) and suradista (B). 
The effects of both compounds were tested on three different tumor cell lines and on three endothelial cell types: bovine microvascular endothelial cells (BMEC), human microvascular endothelial cells (MVEC) and macrovascular endothelial cells (HUVEC). Proliferation and apoptosis were determined on these cells in the absence and presence of suradista and suramin. The influence of both compounds on angiogenesis was determined in an in vitro angiogenesis assay with microvascular endothelial cells.

\section{Materials and methods}

\section{Chemicals}

Suramin (sym-bis(m-amino-benzoyl-m-amino-p-methylbenzoyl-1-naphtylamino4,6,8-trisulfonate carbamide; NSC-34936)) is a polytrisulfonate carbamide ( $M_{r} 1429$; kindly provided by Bayer). The powder was dissolved in water to a stock solution of $100 \mathrm{mg} / \mathrm{ml}$. The concentrations used were in the range between $0.005 \mu \mathrm{g} / \mathrm{ml}$ to $500 \mu \mathrm{g} / \mathrm{ml}$ according to concentrations used by others ${ }^{4,7.8}$.

Suradista $\quad\left(7,7^{\prime}\right.$-(cabonylbis(imino-N-methyl-4,2-pyrrole carbonylimino( $N$-methyl4,2-pyrrole)carbonylimino))-bis(1,3-naphthalene disulfonic acid)tetrasodium salt) is an analog of suramin (kindly provided by Pharmacia \& Upjohn). The freeze dried powder $\left(M_{r} \| 210\right)$ was dissolved in water to a stock solution of $100 \mathrm{mg} / \mathrm{ml}$. The same concentration range as for suramin was used.

\section{Cell culture}

BMEC, a kind gift from Dr. M. Furie (State University New York, Stony Brook, USA), were routinely cultured on collagen $(0.01 \%$; vitrogen-100, Collagen Corporation, Fermont, CA, USA) coated tissue culture plastics (Costar, Cambridge, UK) in $\alpha$-MEM (Life Technologies, Breda, The Netherlands) supplemented with donor calf serum ( $I \mathrm{CN}$, Zoetermeer, The Netherlands) and penicillin/streptomycin (50 IE/ml and $50 \mathrm{ng} / \mathrm{ml}$ respectively; ICN). MVEC and HUVEC were cultured on collagen $(0.01 \%)$ coated dishes in RPMI-1640 (Life Technologies) supplemented with $15 \%$ fetal bovine serum (FBS; Boehringer Ingelheim Biowhittaker, Verviers, Belgium), $15 \%$ human serum, $2 \mathrm{mM}$ glutamine (ICN), $1.5 \mu \mathrm{g} / \mathrm{ml}$ endothelial cell growth supplement (Brunschwig Chemie), $5 \mathrm{IE} / \mathrm{ml}$ heparin (Leo Pharmaceutical Products, Weesp, The Netherlands) and penicillin/streptomycin $(50 \mathrm{IE} / \mathrm{ml}$ and $50 \mathrm{ng} / \mathrm{ml}$ respectively). Tumor cell lines (from the European Collection of Animal Type Cell Culture, ECACC, Salisbury, UK) T47D (mamma carcinoma) and LS174T (colon carcinoma) were cultured in DMEM (Life Technologies) supplemented with 10\% FBS and penicillin/ streptomycin ( $50 \mathrm{IE} / \mathrm{ml}$ and $50 \mathrm{ng} / \mathrm{ml}$ respectively). The Hs578T mammacarcinoma 
cell line (ECACC) was maintained in DMEM with $4.5 \mathrm{~g} /$ glucose, $10 \%$ FBS, 1 $\mathrm{mg} / \mathrm{ml}$ insulin (Life Technologies) and penicillin/ streptomycin $(50 \mathrm{IE} / \mathrm{ml}$ and $50 \mathrm{ng} / \mathrm{ml}$ respectively).

\section{Proliferation assays}

Neutral red assay

The neutral red assay was performed according to the method of Lowwik et al.". In short, cells were seeded in 96 well plates (2500 cells/well). Suramin and suradista were added in different concentrations; after 48 hours neutral red (Sigma) was added. Cells were incubated for another 2 hours, washed, lysed and the optical density was measured.

\section{Tritiated ([ H])-thymidine incorporation}

Cell proliferation was measured using a $\left[{ }^{3} \mathrm{H}\right]$ thymidine incorporation assay ${ }^{10}$. Cells were seeded 1:10 in flatbottomed tissue culture plates and grown for 2 days, in the absence or presence of suramin/suradista. During the last 6 hours of the assay, the culture was pulsed with $0.5 \mu \mathrm{Ci}$ [methyl ${ }^{3} \mathrm{H}$ ] thymidine/well. Activity was measured using liquid scintillation. Results are expressed as the arithmetic mean counts per minute of quadruplicate cultures.

\section{Apoptosis assays}

Apoptotic cells were determined according to the method of Relou". Cells were cultured until confluence and incubated with different concentrations of suramin or suradista. After 24 hours the cells were trypsinized, washed and fixated with $70 \%$ ethanol at $-20^{\circ} \mathrm{C}$ for at least 2 hours. Cells were centrifuged, resuspended in DNA extraction buffer (90 parts $0.05 \mathrm{M} \mathrm{Na}_{2} \mathrm{HPO}_{4}, 10$ parts $0.025 \mathrm{M}$ citric acid and 1 part $10 \%$ Triton $\mathrm{X}-100$ ) for 20 minutes at $37^{\circ} \mathrm{C}$ whereafter propidium iodide (final concentration $0.05 \mathrm{mg} / \mathrm{ml}$; Calbiochem, Omnilabo, Breda, The Netherlands) was added. Stained cells were analyzed on a FACScan flow cylometer (FACSCaliber, Becton Dickinson). Of each sample, forward scatter (FSC) side scatter (SSC) and red fluorescence $(642 / 20 \mathrm{~nm})$ signals of 5000 cells were recorded. The apoptotic cells (subdiploid-peak) and proliferative fraction (4n-DNA peak) can be determined using cell-quest software.

\section{In vitro angiogenesis}

The in vitro angiogenesis assay was performed as described before ${ }^{12}$. Briefly, BMEC were seeded on top of a semi-natural collagen matrix (mixing 8 volumes vitrogen 100 with 1 volume $10 x$ concentrated $\alpha$-MEM and 1 volume sodium bicarbonate $-11.76 \mathrm{mg} / \mathrm{ml}$-) and allowed to grow to a confluent monolayer. To test the possible inhibiting effect of suramin and suradista in this model, different 
concentrations were added to the BMEC culture. Sprouting was induced after 24 hours by the addition of $25 \mathrm{ng} / \mathrm{ml}$ bFGF. After 24 and 48 hours the (sprouting) monolayers were photographed with a Zeiss inverted phase-contrast photomicroscope. The amount of sprouting was quantified by the computer program NHH image 1.58 .

Statistical significance of differences were tested with the Student T-test.

\section{Results}

Suramin expresses anti-neoplastic activity but also toxicity in vivo. Therefore the effects of suramin and suradista on the cell viability were first tested using the neutral red assay. Cell viability decreases for all cell types with increasing concentrations of both suramin and suradista (data not shown). Before neutral red was added the cells were examined. In the presence of suradista concentrations of $50 \mu \mathrm{g} / \mathrm{ml}$ and higher, the tumor cells were not able to form a monolayer but grew in cell clumps which adhered less to the culture dish than the monolayers. This effect was seen for suramin at a concentration of $500 \mu \mathrm{g} / \mathrm{ml}$. During the washing steps in the neutral red assay, those cell clumps were removed due to the decreased adhesion. Although the cells in the cell clumps were viable, detached cells are not included in the neutral red assay. For that reason we decided to determine the cell proliferation with ${ }^{3} \mathrm{H}$-thymidine incorporation in which no cell loss due to decreased adhesion or washing procedures can occur. A concentration range from $0.005 \mu \mathrm{g} / \mathrm{ml}$ to $500 \mu \mathrm{g} / \mathrm{ml}$ of the drug was used for all cell types. Figure 6.2 shows a typical example of cell proliferation for the cells Hs578T and MVEC in the presence of suramin respectively suradista.

For all cell types the results of the ${ }^{3} \mathrm{H}$-thymidine incorporation with the drug concentration of $500 \mu \mathrm{g} / \mathrm{ml}$ are presented in table 6.1. The cells were either incubated directly with suramin and suradista or after having had the possibility to adhere for 24 hours. Proliferation was determined after 48 hours of incubation in the presence of suramin or suradista. The results show that all cells are inhibited at a concentration of $500 \mu \mathrm{g} / \mathrm{ml}$ suramin or suradista. For both inhibitors the tumor cells are affected stronger than the endothelial cells. The effect on the tumor cells was much stronger in the culture in which suramin or suradista was added directly to the culture than in the culture in which the cells were allowed to adhere first. This time effect was limited for the endothelial cells. The microvascular cells seemed to be more sensitive for the effects of both drugs than HUVEC. At the same concentration, suradista was at least as effective as suramin in inhibiting tumor cell proliferation. 

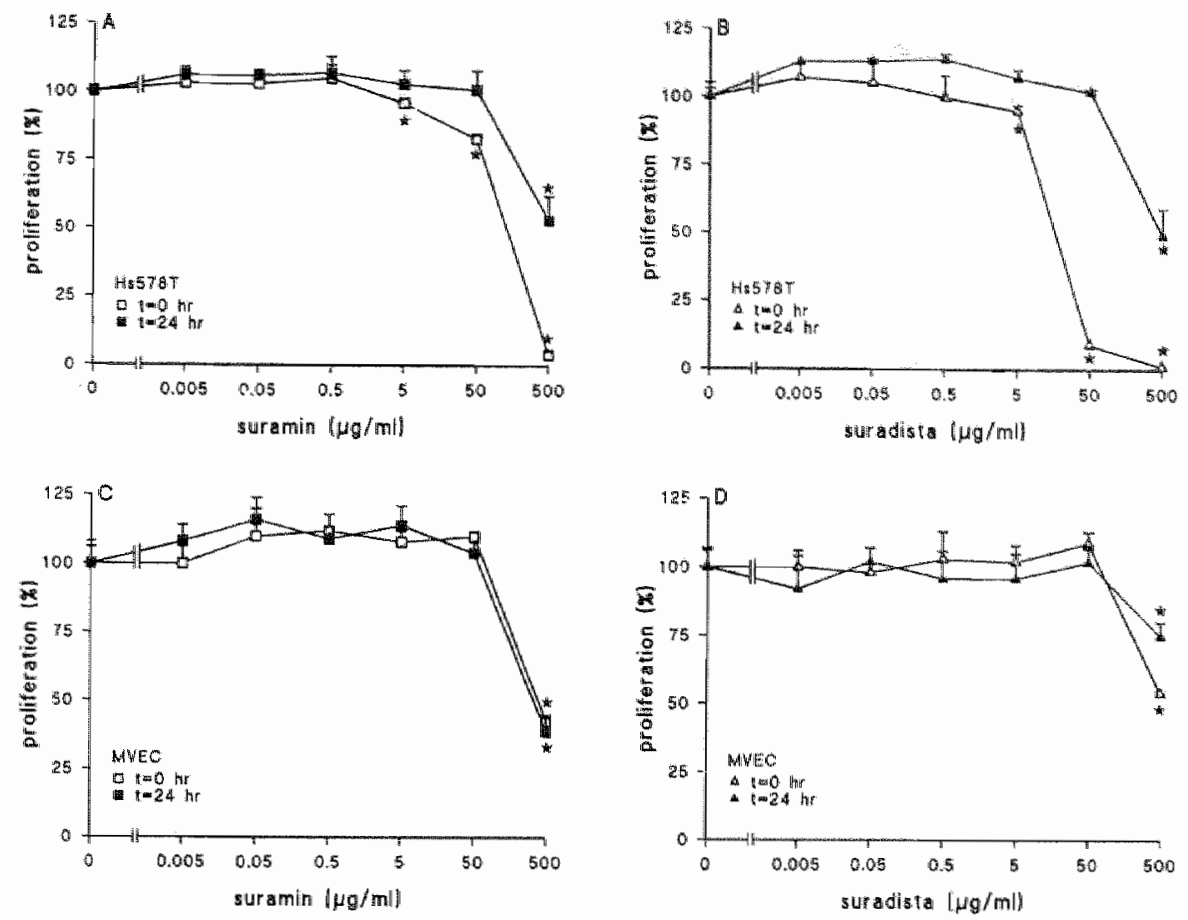

Figure 6.2 Cell proliferation of Hs578T (A,B) and MVEC (C,D) in the presence of increasing concentrations of suramin $(A, C)$ and suradista $(B, D)$. Shown is a representative experiment out of $6(\mathrm{n}=3 \pm \mathrm{sd} ;=\mathrm{p}<0.05)$. Suramin and suradista were added immediately to the culture ( $t=0$ hour) or after having had the possibility to adhere for 24 hours ( $t=24$ hours).

Table 6.1 The results of the cell proliferation measured with "H-thymidine incorporation (in percentage of control). Proliferation of control cultures were set to $100 \%$. Suramin/suradista $(500 \mu \mathrm{g} / \mathrm{ml})$ were added immediately to the culture $(t=0$ hours) or after the cells were allowed to adhere for 24 hours. The cells were culured for 48 hours in the presence of suramin/suradista. (mean $\pm s d ; n=3$ ).

\begin{tabular}{lcccc}
\hline & \multicolumn{2}{c}{ Suradista } & \multicolumn{2}{c}{ Suramin } \\
\hline cell line & 9 hours & 24 hours & 0 hours & 24 hours \\
BMEC & $21 \pm 8$ & $53 \pm 18$ & $33 \pm 3$ & $51 \pm 8$ \\
MVEC & $54 \pm 1$ & $75 \pm 5$ & $43 \pm 2$ & $39 \pm 5$ \\
HUVEC & $78 \pm 3$ & $91 \pm 6$ & $61 \pm 3$ & $63 \pm 2$ \\
T47D & $12 \pm 6$ & $44 \pm 5$ & $29 \pm 5$ & $57 \pm 10$ \\
LS174T & $8 \pm 2$ & $8 \pm 1$ & $4 \pm 1$ & $12 \pm 0$ \\
Hs578T & $1 \pm 0$ & $49 \pm 10$ & $4 \pm 1$ & $53 \pm 9$ \\
\hline
\end{tabular}


The next series of experiments were the measurements of the induction of apoptosis by suramin and suradista. The cells were cultured under standard conditions. Suramin and suradista (both at a concentration range of $5-500 \mu \mathrm{g} / \mathrm{ml}$ ) were added to the culture at the moment of seeding. Apoptosis induction was determined after 24,48 and 96 hours.

Figure 6.3 shows the curves of apoptosis induction by suramin and suradista for the cell line Hs578 $\mathrm{T}$ at a large concentration range. At a concentration of suradista of $50 \mu \mathrm{g} / \mathrm{ml}$ and higher, the cells formed cell clumps and did no longer stuck to the culture plate. For suramin, the formation of cell clumps was found at a concentration of $250 \mu \mathrm{g} / \mathrm{ml}$ and higher. The cells still adhered to the culture plate even at a concentration of $500 \mu \mathrm{g} / \mathrm{ml}$ suramin. At the same concentration at which the cells started to form cell clumps, apoptosis induction was observed. For the Hs $578 \mathrm{~T}$ cells, apoptosis induction with $50 \mu \mathrm{g} / \mathrm{ml}$ suradista was comparable to that obtained with $250 \mu \mathrm{g} / \mathrm{ml}$ suramin (figure 6.3). In the case of the cell lines T47D and LS174T the effect of $50 \mu \mathrm{g} / \mathrm{ml}$ suradista on apoptosis induction was comparable with the effect of $500 \mu \mathrm{g} / \mathrm{ml}$ suramin (data not shown). $50 \mu \mathrm{g} / \mathrm{ml}$ suramin or suradista did not induce significant apoptosis in endothelial cells. $500 \mu \mathrm{g} / \mathrm{ml}$ suradista tends to be more effective in inducing apoptosis in HUVEC and BMEC than suramin but these differences are limited. So at a concentration of $50 \mu \mathrm{g} / \mathrm{ml}$, suradista is able to induce apoptosis in tumor cells but not in endothelial cells. Suramin could induce apoptosis in tumor cells at a concentration of $500 \mu \mathrm{g} / \mathrm{ml}$, but at this concentration the endothelial cells were also killed.

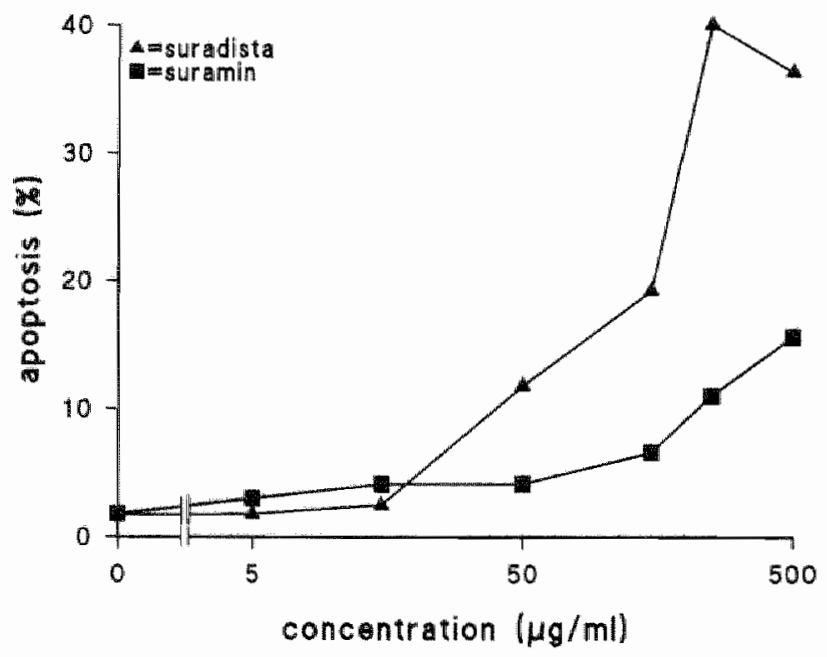

Figure 6.3 Percentage of apoptotic cells for the Hs578T cell line incubated with increasing concentrations of suramin and suradista for 48 hours. Presented is a representative experiment out of 4 . 
Figure 6.4 shows the results for all cell lines incubated for 48 hours in the presence of $500 \mu \mathrm{g} / \mathrm{ml}$ suramin or $500 \mu \mathrm{g} / \mathrm{ml}$ suradista. Suradista was more effective in inducing apoptosis than suramin, except for the MVEC where both compounds induced the same effect.

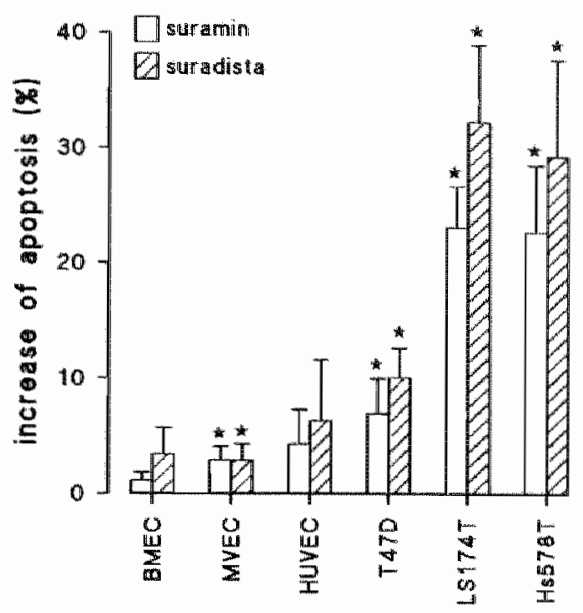

Figure 6.4 Overview of all cell lines cultured in the presence of $500 \mu \mathrm{g} / \mathrm{ml}$ suramin or 500 $\mathrm{kg} / \mathrm{ml}$ suradista. Shown is the increase in apoptosis induction after 48 hours of incubation. Control cells showed apoptosis levels between $1 \%$ and $5 \%$. Shown is the mean $\pm \operatorname{sem}(n=4$ at least; $*=0<0.05)$

Finally, the influence of suramin and suradista on in vitro tube formation was determined. Dose-effect ranges $(5 \mu \mathrm{g} / \mathrm{ml}-500 \mu \mathrm{g} / \mathrm{ml}$ ) of both compounds were tested. The results are shown in figure 6.5. At the lowest concentration tested $(5 \mu \mathrm{g} / \mathrm{ml})$ suramin as well as suradista were abie to slightly inhibit tube formation in vitro. However, when the concentration was increased, significant inhibition could no longer be found. A concentration of $250 \mu \mathrm{g} / \mathrm{ml}$ and higher of suramin or suradista even stimulated sprout formation instead of inhibiting it. So for both drugs the effect on in vitro angiogenesis was biphasic; at low concentrations angiogenesis was slightly inhibited and at high concentrations it was stimulated. 


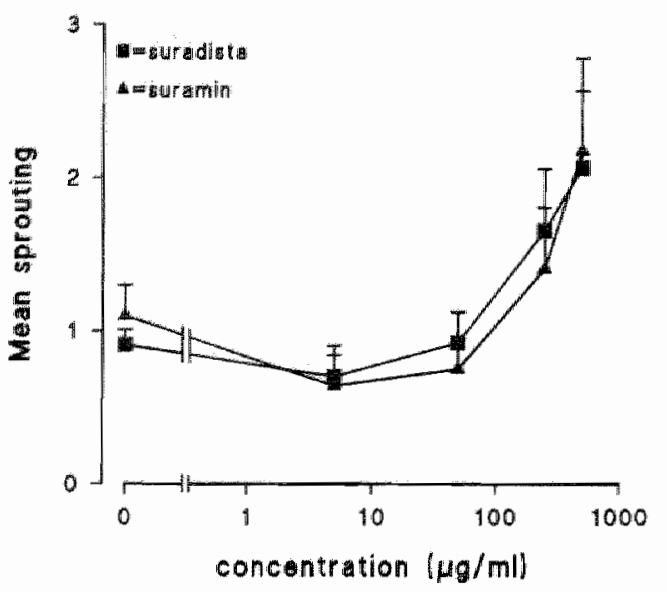

Figure 6.5 In vitro angiogenesis assay. BMEC cultured on top of a collagen layer in the presence of $25 \mathrm{ng} / \mathrm{ml}$ bFGF and increasing concentrations of suramin and suradista. Given is the mean \pm sem of at least 5 experiments.

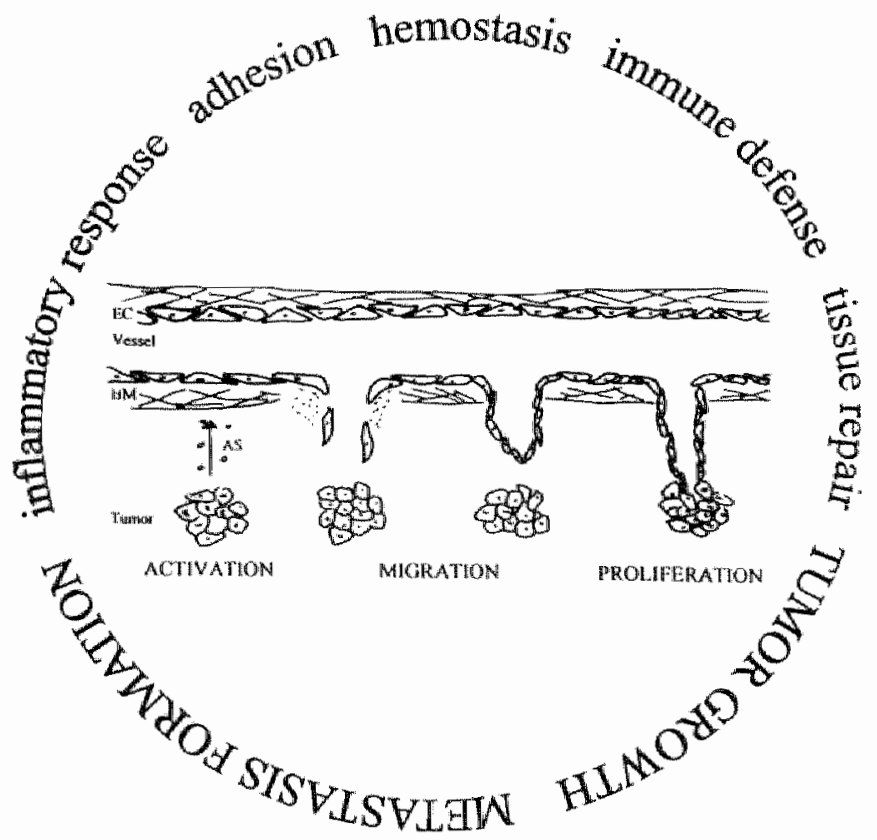

Figure 6.6 Factors inwolved in the formation of new wessels in vivo. Next to activation. migration and proliferation of the endothelial cells, factors as matrix degradation, intlammatory response, haemostasis, immune defense, tissue repair and adhesion are involved. For tumor angiogenesis the net result is that the tumor is able to expand and form meastasis. (BM=basal membrane; $\mathrm{EC}=$ endothelial cells; $\mathrm{AS}=$ angiogenesis stimulator). 


\section{Discussion}

Suramin and its analog suradista have both been tested for their antiproliferative and cytotoxic effects on endothelial cells and on tumor cells in order to find out if suradista could be more promising from the therapeutic point of view than suramin because it induces less toxicity. At equal doses $(500 \mu \mathrm{g} / \mathrm{ml})$ suradista was shown to be at least as effective as suramin in the inhibition of tumor cell proliferation. The antiproliferative effect was larger in tumor cells than in endothelial cells and both compounds were more effective inhibitors of bovine endothelial cell proliferation than of human endothelial cell proliferation (table 6.1). The results thus showed a species difference for the effects of suramin and suradista. The results of suramin inhibition on BMEC and HUVEC proliferation are comparable with those reported by others ${ }^{4,6}$. It was shown that both compounds inhibited cell proliferation less when the cells were first allowed to adhere to the culture dish before the drugs were added. This may be explained by an additional effect of both suramin and suradista on cell adhesion.

Another factor which can inhibit tumor growth is the increase in cell death (apoptosis). For that reason the induction of apoptosis by suramin and suradista was determined. Suramin and suradista were able to increase apoptosis in all cell types although the effect on BMEC and HUVEC was not significant (figure 6.4). In all cases suradista was shown to be more effective in the induction of apoptosis than suramin. At a doses of $50 \mu \mathrm{g} / \mathrm{ml}$ suradista high amounts of apoptosis could still be induced in the tumor cells whereas no apoptosis occurred in the endothelial cells.

Figure 6.3 shows a concentration dependent increase in apoptosis for the cell line Hs578T incubated with both suramin and suradista. Surprisingly, the increase of apoptosis with $500 \mu \mathrm{g} / \mathrm{ml}$ suradista was less than the increase with $250 \mu \mathrm{g} / \mathrm{ml}$ suradista. However, when we studied the results of the total amount of cell death, including necrosis, for the Hs578T cells we found that this was higher for $500 \mu \mathrm{g} / \mathrm{ml}$ than for $250 \mu \mathrm{g} / \mathrm{ml}$ suradista. This apparent contradiction could be explained by the fact that late apoptotic cells could not be distinguished from necrotic cells and for that reason are not included in the results.

Angiogenesis is a multistep process (figure 6.6). Endothelial cells are first activated to synthesize proteolytic enzymes after which digestion of the basement membrane and migration of endothelial cells can take place. Subsequently the budding sprout proliferates to expand and form a lumen necessary for the establishment of mature and elongated vessels. This part of the angiogenic process can be mimicked in vitro and thus in vitro angiogenesis assays can be used to study the individual steps involved. However, in the in vivo situation, other processes like the inflammatory 
response, immune defense and hemostasis are involved in vessel formation as well. Therefore, as Folkman stated ${ }^{13}$, endothelial cell proliferation assays are poor predictors of (anti-)angiogenic potency in wivo because there are so many additional factors which determine if cells are able to form tubes. For that reason we not only tested suramin and suradista in in vitro proliferation and apoptosis assays, but also in an in vitro angiogenesis assay, in which factors like matrix degradation and migration are included. Figure 6.5 shows that both compounds induced the same effects on in vitro angiogenesis. At concentrations at which both compounds did not affect the proliferation or apoptosis $(5 \mu \mathrm{g} / \mathrm{ml})$, suramin and suradista were both able to inhibit tube formation in vitro but when the concentration is increased angiogenesis no longer was inhibited but instead it seemed to be induced. So a clear biphasic effect of both compounds was found. A comparable dose-dependent effect was reported by Fidler for interferon treatment in hemangioma patients ${ }^{14}$. At low sustained dosages of interferon- $\alpha$ angiogenesis was inhibited whereas high dosages of interferon were not effective. In our hands no correlation between proliferation assays and the in vitro angiogenesis assay could be found. There are of course some differences in experimental setup between the proliferation and apoptosis assay and the angiogenesis assay. For the proliferation and apoptosis assays the cells were cultured on a thin coat of collagen. The drugs were added to these cultures before the cells were able to form a confluent layer. For the multistep in vitro angiogenesis assay the cells were cultured on a thick layer of collagen. Suramin and suradista were added to the culture after the cells had formed a confluent layer. It could be that the thick matrix on which the cells were culltured in the in vitro angiogenesis assay is able to protect the endothelial cells against the effects of suramin and suradista. Another hypothesis might be that, as only a low amount of cells is forming the tubes, it are just those sprouting cells which are not sensitive for the drugs. Yet another explanation could be that both drugs are less effective on a confluent cell layer than on a subconfluent layer or on cells which even had to adhere first. The results of the proliferation assay in which the time point of addition of the drugs is varied supports this latter hypothesis.

It has been reported by others that suramin is able to inhibit angiogenesis in the chorioallantoic membrane assay (CAM) $)^{1,4,15}$. Maybe in the CAM assay the new vessel formation is partly vasculogenesis instead of angiogenesis which could explain why suramin is able to inhibit vessel formation in the CAM but not in our angiogenesis model. Other "environmental factors" like the presence of immune cells and of a hemostatic system, which are present in the in vivo CAM-assay but absent in an in vitro assay, could also influence the results.

From our results we can conclude that suradista is more effective in inhibiting tumor cells, at least in vitro, and is less cytotoxic on endothelial cells than suramin. In the angiogenesis assay both compounds induced the same effects. 


\section{References}

1. Morris AD, Léonce S, Guibaud $N$, Tucker GC, Pérez $\mathrm{V}$, Jan M. Cordi AA, Pierre A, Atassi G. Eriochrome Black T, structurally related to suramin inhibits angiogenesis and tumor growth in vivo. Anti-Cancer Drugs 1997:8:746-755.

2. Nakajima $M$, DeChavigny $A$, Johnson CE, Hamada J-I, Stein CA, Nicolson GL. Suramin. A potent inhibitor of melanoma heparinase and invasion. J. Biol Chem. $1991 ; 266: 9661-9666$.

3. Gastl $G$, Hermann $T$, Steurer $M$, Zmija J, Gunsilius $E$, Unger $C_{\text {" Kraft A. }}$ Angiogenesis as a target for tumor treatment. Oncology 1997;54:177-184.

4. Takano S, Gately S, Neville ME, Herblin WF, Gross JL, Engelhard H, Perricone M, Eidsvoog $\mathbb{K}$, Brem S. Suramin, an anticancer and angiosuppressive agent, inhibits endothelial cell binding of basic fibroblast growth factor, migration. proliferation, and induction of urokinase-type plasminogen activator. Cancer Res $1994 ; 54: 2654-2660$.

5. Mirza MR, Jakobsen E, Pfeiffer P, Lindebjerg-Clasen B, Bergh J, Rose C. Suramin in non-small cell lung cancer and adwanced breast cancer. Acta Oncologica 1997; 36:171-174.

6. Braddock PS, Hu D-E, Fan T-PD, Stratford IJ, Harris AL, Bicknell R. A structure-activity analysis of antagonism of the growth factor and angiogenic activity of basic fibroblast growth factor by suramin and related polyanions. $\mathrm{Br} J$ Cancer 1994;69:890-898.

7. Boylan M, Van den Berg HW, Lynch $M$. The anti-proliferative effect of suramin towards tamoxifen-sensitive and resistant human breast cancer cell lines in relation to expression of receptors for epidermal growth factor and insulin-like growth factor-I: growth stimulation in the presence of tamoxifen. Annals Oncol 1998; 9:205-2:11.

8. Lindman H, Taube A, Bergh JCS. Suramin inhibits the growth of human breast cancer cell lines. Studies on parental lines and corresponding sublines with acquired doxorubicin resistance with and without expression of P-glycoprotein. Anticancer Res $1994 ; 14: 363-366$.

9. Löwik CWGM, Alblas MJ, Van de Ruit M, Papapoulos SE, Van der Pluijm G. Quantification of adherent and nonadherent cells cultured in 96-well plates using the supravital stain neutral red. Anal Biochem 1993;213:426-433.

10. Griffioen AW, Coenen MJH, Damen CA. Hellwig SMM, Van Weering DHJ, Vooys W, Blijham GH, Groenewegen $\mathrm{G}, \mathrm{CD} 44$ is involwed in tumor angiogensis; an activation antigen on human endothelial cells. Blood 1997;90:1150-1159.

11. Relou IAM, Damen CA, van der Schaft DWJ, Groenewegen GG, Griffioen AW. Effect of culture conditions on endothelial cell growth and responsiveness. Tissue \& Cell 1998; in press.

12. Barendsz-Janson AF, Griffioen AW. Muller AD, Van Dam-Mieras MCE, Hillen HFP. In vitro tumor angiogenesis assays: plasminogen lysine binding site 1 inhibits in vitro tumor induced angiogenesis. J Vasc Res 1998;35:109-114. 
13. Folkman J. Antiangiogenic therapy. In: Cancer: Principles \& practice of oncology. 5 ed. DeVita VT, Hellman S, Rosenberg SA, ed. Philadelphia: Lippincott-Raven Publishers, 1997:3075-3085.

14. Fidler 1J. Angiogenesis in the pathogenesis of cancer metastasis. In: Proceedings Angiogenesis and Cancer. Folkman J, Klagsbrun M, ed. Orlando, 1998.

15. Gagliardi ART, Kassack M, Kreimeyer A, Muller G, Nickel P, Collins DC. Antiangiogenic and antiproliferative activity of suramin analogues. Cancer Chemother Pharmacol 1998;41:117-124. 


\section{Chapter 7}

Angiogenic potential of malignant and non-malignant human breast tissues in an in vivo angiogenesis model

HC Lichtenbeld, AF Barendsz-Janson, H Van Essen, H Struijker Boudier, AW Griffioen, HFP Hillen 


\section{Abstract}

Tumors need to acquire the angiogenic phenotype for outgrowth and metastasis formation. Limited information on the angiogenic potential of specific tissues, especially human breast tissues is available. Here we describe an in vivo model, using the dorsal skin fold chamber in immunodeficient nude mice, where various tissues of human breast origin were xenografted and evaluated for their angiogenesis inducing potential. We found that angiogenesis was abundantly induced by all breast carcinoma tissue samples. Similar angiogenesis was induced by tissue samples from breasts with hyperplasia and apocrine metaplasia. Histologically normal tissues adjacent to the tumor induced angiogenesis in $66 \%$ of the cases. Anglogenesis was not induced by control tissues from normal healthy breasts, obtained after cosmetic breast reduction. Angiogenesis induction parallelled the VEGE production by the tumor cells. The tissue induced neovascularization, found both around and in the human tissue, was functional since a tail vein injection with albuminFITC revealed within 5 minutes a positive tumor microcirculation and the tumor tissue still consisted of vital human epithelial cells after 14 days. The qualitative and quantitative information on the angiogenic activity of specific viable human tissues may add an essential aspect to the diagnostic and predictive applications currently used. 


\section{Introduction}

Clinical and fundamental cancer research has been focussed mainly on the proliferative and genetic aspects of tumor cells. It has been demonstrated over the last years that tumors are dependent on the switch to an angiogenic phenotype and the subsequent formation of new vasculature ${ }^{1,2}$. Histological studies on the correlations between tumor microvessel density and prognosis support these findings. However, results are not unequivocal ${ }^{3-6}$. Although these studies show the importance of the angiogenic concept for clinical purposes, they do not provide information on the angiogenic potential of specific tissues.

Human tissues have been evaluated in a variety of in vitro and in vivo models for their growth and metastatic behaviour, but little is known on their capacity to induce neovascularization. Human cancer tissue has been transplanted in various animal models to study the biology and therapeutic aspects of these tunors ${ }^{7 \cdot 13}$. In this work we describe a sensitive in vivo angiogenesis model in which various types of human breast tissues, obtained directly from patients, were investigated for their angiogenesis inducing capacity. It was possible to reliably identify the angiogenic potential of malignant, premalignant and non-malignani tissues, i.e. histologically normal tissue biopsies derived from breasts with confirmed carcinomas, and breast tissues of patients with hyperplasia and apocrine metaplasia. Extended use of this model with tissues from different sources will ultimately allow prognostic and predictive applications.

\section{Materials and Methods}

\section{Animals}

Immunodeficient mice (female Swiss nu/nu mice) were kept under aseptic conditions, fed ad libitum, and used for experiments at 10-12 weeks of age. All animal studies were approved by an institutional ethical review committee.

For surgery, mice were anaesthetized s.c. (ketamine-HCl, $7.5 \mathrm{mg} / 100 \mathrm{~g}$ body weight and xylazine $2.5 \mathrm{mg} / 100 \mathrm{~g}$ body weight). Mice were kept at $37^{\circ} \mathrm{C}$ during surgery.

\section{Dorsal skin fold chamber}

The dorsal skin fold chamber described previously ${ }^{14.15}$ was adapted for these studies. This model is particularly suitable for continuous evaluation of the angiogenic response. Briefly, the skin of the back of a mouse was sandwiched as a double layer between two symmetrical titanium frames, which are mirror images of each other. In a circular opening in the chamber (15 $\mathrm{mm}$ in diameter), one layer of 
skin was removed. The remaining layer, consisting of epidermis, subcutaneous tissue and striated skin muscle was covered with a sterile glass coverslip. Surgical procedures were performed under aseptic conditions. Chambers with intact microcirculation were used for the inoculation of human tissue.

\section{Tissue xenotransplantation in the dorsal chamber}

Breast tissue biopsies from women with confirmed diagnosis of primary breast cancer were randomly obtained. Biopsies from normal breast tissues were obtained from the Department of Plastic Surgery. Breast tissues are divided in four groups: 1) tumor tissues; biopsies from tumor of patients with primary breast cancer with or without axillary nodal metastases, 2) histologically normal tissues distant from the humor; histologically normal breast tissue obtained from the involved breast of patients with primary breast cancer; these biopsies were screened by an experienced pathologist to confirm normal histology, 3) control tissues; normal breast tissue obtained from patients undergoing breast reductive plastic surgery, 4) hypertrophic tissues; tissues from patients with hyperplasia and apocrine metaplasia.

Clinical staging of the patients with primary breast cancer was performed according to the TNM-system. Tumor specimens were immunohistologically assayed for the levels of estrogen receptors (DPC, Apeldoorn, The Netherlands) and progesterone receptors (Tamer, Uithoorn, The Netherlands), and classified as positive when $>10 \%$ of the cells were stained.

Tissues were delivered under semi-septic conditions immediately after surgery. They were then transferred to an aseptic environment and most fat tissue was removed. All tissue samples contained connective tissue and epithelial cells. Samples were cut into pieces of approximately $5 \mathrm{~mm}^{3}$ to provide sufficient nutrient supply and thus minimize cell death during cell culture. Tissue pieces were incubated for $3-5$ days in Biopsy Culture (BC) medium, defined as Dulbecco's Modified Essential Medium (GlBCO, Gaithersburg, MD) supplemented with 20\% bovine serum and antibiotics (penicillin $100 \mathrm{I} . \mathrm{E} . / \mathrm{ml}$ and streptomycin $0.1 \mathrm{mg} / \mathrm{ml}$ ). This treatment prevented bacterial contamination, which is a prerequisite for transplantation in immunodeficient mice. VEGF levels in this culture medium were measured using a VEGF ELISA-kit (R\&D-systems, Abbington, UK). After 3-5 days, a single small piece of tissue was xenografted onto the striated muscle of the skin in the dorsal chamber. The tissue samples were evaluated for angiogenesis induction every other day. At day 14, mice were sacrificed and tumors excised and frozen for immunostaining. To evaluate the viability of the human tissue cells, sections were routinely stained with hematoxylin/eosin and with the anti-human cytokeratin marker MNF116, (ITK, Uithoorn, The Netherlands). 


\section{Determination and analysis of angiogenesis in vivo}

Every other day, mice were placed in a plastic holder that allowed observations of the chambers, without the need of anaesthetics. Preparations were observed through a stereomicroscope (Leica, Rijswijk, Netherlands) for the formation of new blood vessels. Photographs were taken at day 7 and at the end of the experiment (day 14). Quantification of vessel density was performed by digitizing images from the tissue samples in the dorsal chamber and analysis with a Quantimed 570 image analysis system (Leica). The amount of vascularization was quantified using a Vessel Density Index (D) according to the equation:

$\mathrm{D}=\mathrm{L} / \mathrm{A}$

where $L$ is the total length ( $\mathrm{mm}$ ) of all individually measured microvessels and $A$ is the total surface area $(\mathrm{mm} 2)$ of the implanted biopsy.

To evaluate the reproducibility of the in vivo model, 4 samples from the same tumor biopsy were inoculated in 4 different mice and evaluated for their angiogenesis inducing capacity as described above.

To identify the origin of the vessels in and around the biopsy, tissues (before and after transplantation in the dorsal chamber) were tested with a specific anti-mouse endothelial antibody (Meca20; a kind gift of Dr A Duijvestijn, Maastricht, The Netherlands) according to a protocol described previously ${ }^{16}$.

\section{Vessel functionality}

Mice, bearing a dorsal chamber with human tissue, were anaesthetized as described above. The fluorescent marker FITC-albumin (Sigma, St Louis, MO) was injected $(0.1 \mathrm{ml}, 80 \mathrm{mg} / \mathrm{ml})$ in the tail vein of the mouse 5 minutes prior to intravital microscopy. Next, the animal was placed in a holder which allowed the mouse to remain in upright position, while the microscope objective was in horizontal position. The preparation was observed with a Leitz Orthoplan microscope (Zeiss, Germany, with Zeiss plan objectives of $2.5 x, 4 x, 10 x, 11 x)$ under epi-illumination (Ploemopak illuminator, 1.25x tube factor). The illuminator was equipped with a Leitz interchangeable filter cube (I-2 type) in combination with a $100 \mathrm{~W}$ mercury lamp. Images were visualized with an intensified CCD-camera (Hamamatsu electronics, Hamamatsu, Japan), and a video monitor and stored on videotape for off-line analysis.

\section{Results}

To determine the angiogenic potential of breast cancer tissue, we xenografted tumor biopsies into the mouse dorsal skin fold chamber. Induction of angiogenesis was observed in all of the tumor biopsies $(10 / 10)$. The earliest detection of newly 
formed vessels appeared between 4-8 days after transplantation. These vessels exhibited a tortuous architecture, surrounding and invading the tumor tissue (figure 7.1a). The mean vessel density measured was $1.285 \pm 0.275(n=10)$ which was significantly different $(p<0.0001)$ from the vessel density measured in chambers carrying normal breast tissues obtained after reductive breast surgery $(0.073 \pm 0.052, n=3$, figure $7.1 \mathrm{~b})$. Although there was not a large variety in Vessel Density Index between the different tumors, we performed a reproducibility assay. Therefore one tumor was transplanted in four different mice. The first vessels were induced at day 4 in all four animals and the vessel densities after 14 days were comparable $(1.392 \pm 0.08)$. We conclude therefore that the variability observed in the angiogenic responses of the breast tumor tissues, was not due to biological variability in the model itself (table 7.1).

The tumor induced vessels were functional as measured by perfusion with the FITC-albumin fluorescent marker injected in the tail vein. The marker appeared in the vasculature of the mouse skin, within five minutes post injection. After approximately 10 minutes, FITC-albumin was observed in the tumor microcirculation and disappeared subsequently within the following 10 minutes due to clearance and bleaching of the probe.

Clinical data such as tumor stage, hormone receptor status or patient age did not seem to determine the angiogenic response of the implanted tissue (table 7.1).

Also histologically normal tissues distant from the tumor were tested for induction of angiogenesis. Sections from these normal breast tissues were analyzed to exclude the presence of ductal carcinoma, carcinoma in situ or atypical hyperplasia. We found varying responses with these tissues. In two out of six cases no induction of angiogenesis was found, similarly to the control tissues (figure $7.1 \mathrm{c}$ ). In the other four samples a moderate to strong angiogenesis induction was observed (figure 7.1d). The angiogenic response that occurred was both qualitatively as well as quantitatively different from tumor-induced angiogenesis. Newly formed vessels were less tortuous and invaded rather than surrounded the tissue samples compared to the vessels induced by the tumors. Also, the angiogenesis response was significantly less pronounced than the tumor induced response, as indicated by the vessel density index $D(0.583 \pm 0.263$ versus $1.285 \pm 0.275, \mathrm{p}<0.001)$.

Interestingly, the hypertrophic breast tissue biopsies obtained from patients with hyperplasia and apocrine metaplasia also induced vessel formation. These samples also showed differences in vessel architecture as compared to both tumor and normal tissues. The vessels were longer and more regular vascular patterns were observed. The earliest vessels were observed at day 4 (vs. $7.6 \pm 2.5$ days in tumors) and the average vessel density index was significantly higher $(1.827 \pm 0.254, p<0.01, n=4)$ than the vessel index of tumor tissues. 


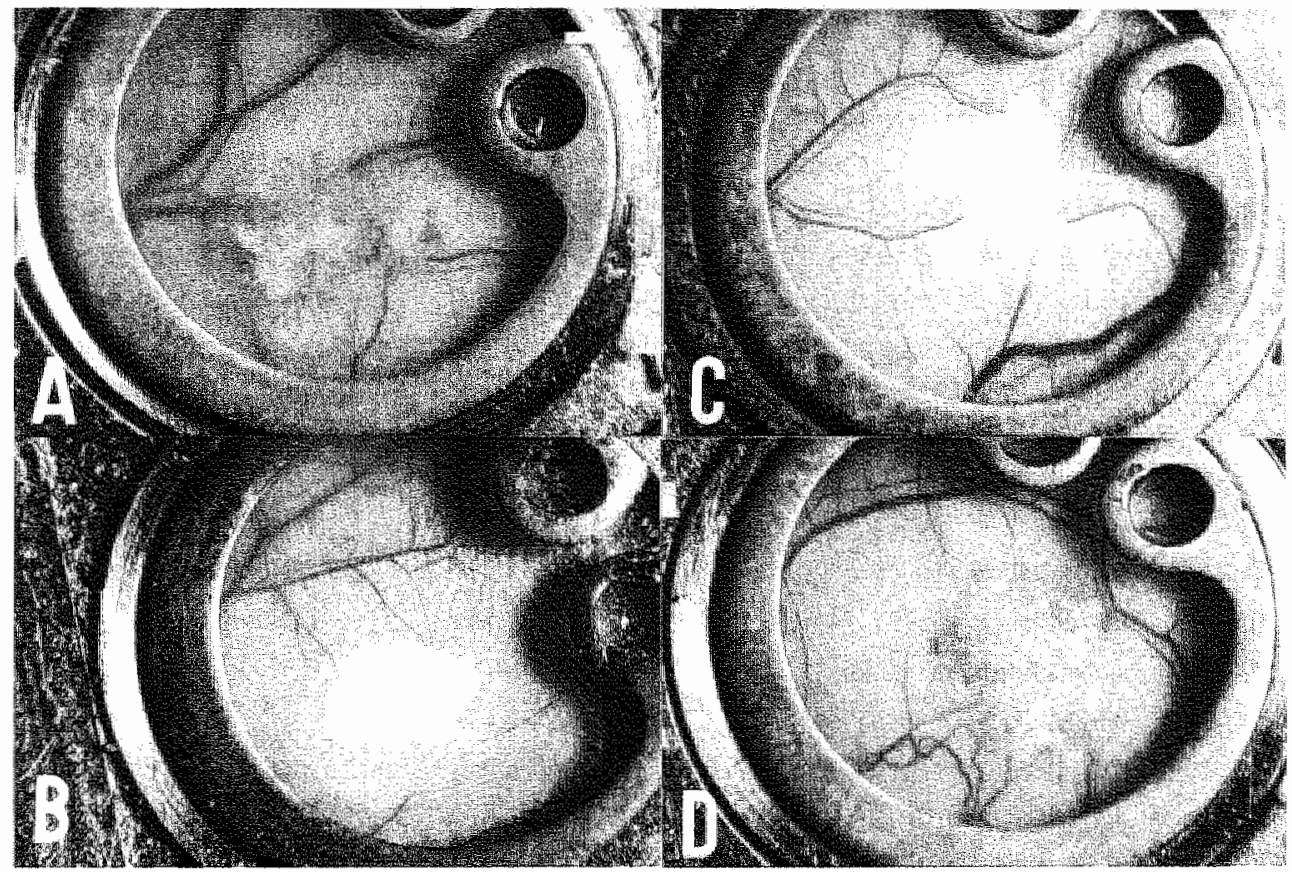

Figure 7.1 Angiogenesis induced by human breast tissue in the mouse dorsal skin fold chamber. A. Tumor biopsy transplanted on the striated muscle layer. B. Controll tissue sample. C. Normal tissues distant from the tumor (non-angiogenic). D. Normal tissues distant from the tumor (angiogenic). The bar in the upper right corner of $A$ represents $2 \mathrm{~mm}$.
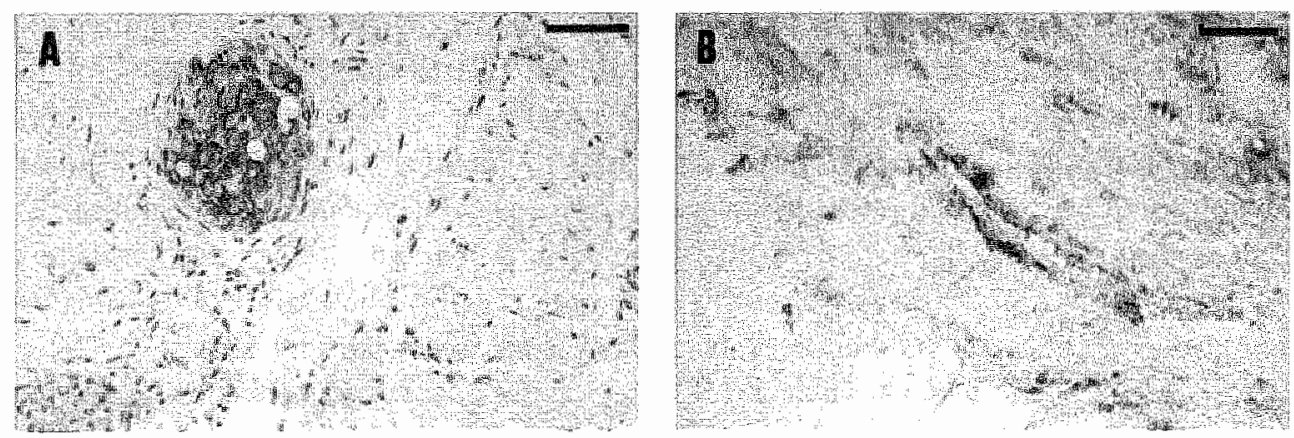

Figure 7.2 Histological analysis. A. Presence of human epithelial cells in the tissue sample, 14 days after implantation in the dorsal chamber. Staining with MNFll6 human keratinocyte antibody. The bar represents $100 \mu \mathrm{m}$. B. Meca20 ant-mouse endothelium immuno-staining of mouse endothelial cells in angiogenesis inducing human breast cancer biopsy $(200 x), 14$ days post rransplantation. The har represents $50 \mu \mathrm{m}$. 
Table 7.1 Transplanted human breast tissues in the mouse dorsal skin fold chamber. Histology, clinicall data, earliest vessel detection and vessel density.

\begin{tabular}{|c|c|c|c|c|c|c|c|}
\hline \multirow{2}{*}{$\begin{array}{l}\text { Sample } \\
\text { number }\end{array}$} & \multirow[t]{2}{*}{ Histology } & \multirow{2}{*}{$\begin{array}{l}\text { Age } \\
(y r)\end{array}$} & \multirow{2}{*}{$\begin{array}{c}\text { Earliest } \\
\text { new vessels } \\
\text { (duys) }\end{array}$} & \multirow[t]{2}{*}{ Vessel density } & \multicolumn{3}{|c|}{ Clinical data } \\
\hline & & & & & Tumor stage & $\mathrm{ER}$ & PgR \\
\hline \multicolumn{8}{|l|}{ Tumors } \\
\hline 1 & lobular carcinomat & 68 & 6 & 1.001 & T2N1M0 & $\frac{1}{1}$ & s. \\
\hline 2 & inf. ductal ca. & 58 & 6 & 1.004 & TIN1MO & - & - \\
\hline 3 & inf. ductall ca. & 47 & 5 & 1.047 & T2N1MO & - & + \\
\hline 4 & inf. ductall ca. & 49 & 5 & 1.099 & TINOMO & - & - \\
\hline 5 & inf. ductal ca. & 87 & 6 & 1.182 & T2NOMO & - & + \\
\hline 6 & infe ductal ca. & 84 & 4 & 1.262 & $\mathrm{~T} 4 \mathrm{~N} 2 \mathrm{M} 0$ & 。 & - \\
\hline 7 & int. ductal ca. & 79 & $4 \pm 0(n=4)$ & $1.392 \pm 0.08(n-4)$ & T1N1MO & + & + \\
\hline 8 & infe ductal cat. & 87 & 4 & 1.411 & T2NOMO & - & + \\
\hline 9 & infif. ductal cat. & 50 & 8 & 1.690 & T2NOMO & - & - \\
\hline 10 & inf. ductal ca. & 49 & 6 & 1.766 & TINOMO & 。 & - \\
\hline
\end{tabular}

Normal tissue distant from the tumor

\begin{tabular}{|c|c|c|c|c|}
\hline $\mathbb{1}$ & normal & 52 & 7 & 0.032 \\
\hline 2 & nomial & 49 & 12 & 0.079 \\
\hline 3 & nornual & 95 & 9 & 0.260 \\
\hline 4 & normal & 49 & 6 & 0.484 \\
\hline 3 & nonmal & 72 & 5 & 0.741 \\
\hline 5 & nornal & 65 & 7 & 0.845 \\
\hline \multicolumn{5}{|c|}{ Controls } \\
\hline I. & normal & 16 & - & 0.022 \\
\hline 2 & normal & 39 & - & 0.071 \\
\hline 3 & normal & 30 & - & 0.126 \\
\hline \multicolumn{5}{|c|}{ Hyperplasiatand apocrine metaplasia } \\
\hline$\|$ & hypertrophic & 40 & 4 & 1.581 \\
\hline 2 & hypertrophic & 51 & 4 & 1.712 \\
\hline 3 & Inypertrophic & 57 & 4 & 1.843 \\
\hline 4 & mypertrophic & 32 & 4 & 2.174 \\
\hline
\end{tabular}

VEGF levels were measured in the culture medium in which the tissues were incubated (see M\&M section). We found in the tumor tissue mean VEGF levels of $1188 \mathrm{pg} / \mathrm{ml}$ (range $693-1394 \mathrm{pg} / \mathrm{ml}$ ), while control tissues and the histological nomal tissues from carcinoma patients that did not induce in vivo angiogenesis, 
had mean VEGF levels of $120 \mathrm{pg} / \mathrm{ml}$ (range $98-145 \mathrm{pg} / \mathrm{ml}$ ). In the breast tissue with hypertrophic morphology elevated mean VEGF levels were found of $850 \mathrm{pg} / \mathrm{ml}$ (range $375-1353 \mathrm{pg} / \mathrm{ml}$ ).

At day 14 tissues were excised from the chamber and used for histological evaluation. Immunohistochemistry showed that biopsies were firmly anchored to the striated muscle layer of the skin, and that granulation tissue could be found at the implantation site of the angiogenesis inducing tissues.

Since transplants in mice, after a prolonged time, can express a different histology compared to the original ${ }^{17.18}$, we determined the presence of viable human cells after 14 days, by morphological analysis of routine hematoxylin/eosin stained sections. Human epithelial cells, as visualized by human cytokeratin MNFI16 staining, in the chamber preparation after 14 days were still viable (figure $7.2 \mathrm{a}$ ). The origin of the vessel structures found in the angiogenesis inducing tissue specimens were identified immunohistologically as mouse endothelial cells (figure $7.2 \mathrm{~b})$.

\section{Discussion}

Outgrowth of tumors and metastasis formation are dependent on angiogenesis. Measurement of an overall angiogenic potential of tumors might therefore contribute to the prognosis of cancer. With the model described in the present study, it is possible to evaluate this angiogenic potential of different tissues. All tumor samples, which presumably already expressed the angiogenic phenotype, consistently elicited a strong angiogenic response. Induction of neovascularization was therefore not correlated with clinical stage, hormone receptor status or age of the patient. The differences in vessel density index measured between the different tumors, which was demonstrated not to be caused by variation in the assay system, might therefore serve as a prognostic value. Variability in the size of the transplanted biopsies or amount of leukocyte infiltration might influence the level of angiogenesis induction. However, we transplanted similar sized tumor samples reducing the possibility of transplanting different amounts of tumor cells. Regarding the amount of leukocytes, the presence of infiltrate is also a tumor induced parameter indirectly able to enhance induction of angiogenesis and therefore also of importance in situ.

The mechanism of angiogenesis induction by human tissues in the dorsal skin fold chamber is the (direct or indirect) production of angiogenic factors. It can be excluded that the neovascularization is induced by VEGF induction in the tumor tissue due to hypoxic conditions in the dorsal skin fold chamber, because nomal tissues cultured and transplanted under the same conditions do not induce angiogenesis. 
The results obtained with the histologically normal tissues from breasts with adenocarcinomas were unexpected. In this tissue type, four out of six samples induced an angiogenic response. We favour the view that circulating tumor derived angiogenic factors ${ }^{19}$ are involved in this neovascularization. Indeed we found elevated levels of VEGF in these tissues. In earlier research ${ }^{20}$ high expression of VEGF-receptors in endothelial cells of vessels adjacent to malignant breast tumor cells were observed. These and our observations indicate that angiogenic factors, produced by the cells of breast tumors, may have significant effects on residual normall tissue and especially on endothelial cells of the surrounding blood vessels. We found exuberant angiogenic responses after transplantation of breast tissues of hyperplasia and apocrine metaplasia. This shows that angiogenesis can be induced not only by cancerous tissue but also by benign hypertrophic lesions.

The VEGF levels in the breast cancer samples were significantly higher than in normal tissue controls. This is consistent with recent studies in breast cancer ${ }^{20,21}$, but we also found elevated levels of VEGF in non-malignant hypertrophic breast tissues. The levels of VEGF produced by the investigated tissues completely parallelled the capacity to induce in vivo angiogenesis. This result suggests that VEGF is at least one of the factors involved in the stimulation of angiogenesis in the in vivo model. In addition, the positive correlation between VEGF production and the induction of angiogenesis in the different tissue samples confirms the hypothesis of a multistep angiogenic mechanism from benign to malignant lesions of the breast $t^{2.22}$.

Another important finding was that the vasculature, as induced by the biopsies, was functional and sufficient to supply the human tissue with nutrients for 14 days. The first observation was based upon the fact that within 10 minutes after intravenous injection of a fluorescent marker, perfused vessels were identified in the newly vascularized tissue sample that was transplanted in the chamber. The second observation was confirmed with the evaluation of the immunostaining for the cytokeratin MNF116, which recognizes human epithelial cells.

The detection of newly formed vessel structures from mouse origin with the Meca20 mouse endothelium-specific antibody supported the finding that the newly formed vessels were of mouse origin. Vascular structures in the implanted tissue sample itself disappeared during the 3-5 days in vitro incubation and could not be detected thereafter. It is unlikely that these pre-existing vessels later gave rise to the vessels formed in and around the biopsy.

Currently, in addition to physical examination of cancer patients, we mainly rely on pathological, immunohistological indicators and gene aberrations for diagnosing malignancy. Especially in the heterogeneous behaviour of breast cancer, these tools have often been insufficient and additional methods are needed. The use of animal models for diagnostic, prognostic and therapeutic means has been questioned, since variability between experimental settings largely influences the outcome of the 
study. The model described in this paper displays consistent differences between different tissue types, i.e. malignant, non-malignant, hyperplastic and normal tissues, making it valuable to evaluate angiogenic potential of human tissues. This in vivo angiogenesis model may be a useful tool for the study of angiogenic diseases and, in the future, may be used as an independent diagnostic, predictive and/or therapeutic indicator. 


\section{References}

1. Folkman J. What is the evidence that tumors are angiogenesis dependent? J Natl Cancer Inst 1990;82:4-6.

2. Folkman J. Angiogenes is in cancer, vascular, rheumatoid and other disease. Nature Med 1995;1:27-31.

3. Weidner $\mathrm{N}$. Intratumor microvessel density as a prognostic factor in cancer. Am J Pathol 1995; 147:9-19.

4. Casparini $G$, Weidner $N$, Bevilacqua $P$, Maluta $S$, DallaPalma P, Caffo $O$, Barbareschi $M$, Boracchi $P$, Marubini E, Pozza F. Tumor microvessel density, p53 expression, tumor size, and peritumoral lymphatic vessel invasion are relevant prognostic markers in node-negative breast carcinoma. J Clin Oncol 1994;12: $454-466$.

5. Axelsson K, Ljung BM, Moore II. DH. Thor AD, Chew KL, Edgerton SM, Smith HS, Mayall $\mathrm{BH}$. Tumor angiogenesis as a prognostic assay for invasive ductal breast carcinoma, d Natl Cancer Inst 1995;87:997-1008.

6. Barbareschi M, Gasparini G, Morelli L, Forti S, Dalla Palma P. Novel method for the determination of the angiogenic activity of human tumors. Breast Cancer Res Treat 1995;36:181-192.

7. Jain RK, Schlenger K, Höckel M, Yuan F. Quantitative angiogenesis assays: progress and problems. Nature Med 1997;3:1203-1208.

8. Shimosiato $Y$, Kameya $T$, Hirohashi $S$. Growth, morphology, and function of xenotransplanted human tumors. Patiol Anmu 1979;14:215-257.

9. Jensen HM, Chen I, DeVault MR, Lewis AE. Angiogenesis induced by "normal" human breasi tissue: a probable marker for precancer. Science 1982;218:293-295.

10. Giovanella BC, Vardeman DM, Williams LJ, Taylor DJ, Delpolyi PD, Greeff PJ, Stehlin JS, Ulrich A, Cailleau A, Slamon DJ, Gary HE. Heterotransplantation of human breast carcinomas in nude mice. Correlation between successful heterotramsplants, poor prognosis and amplification of the HER-2/neu oncogene. Int I Cancer 1991:47:66-71.

11. Coil DR, Giovanella BC, Greeff PJ, Stehlin IS, Davis BR. An experimental model for the study of thermochemotherapy in vivo. Anticancer Res 1992;12:1363-1371.

12. Mehta RR, Graves JM, Warso MA, DasGupta TK. Overexpression of mutant p53 and c-erbB-2 proteins and breast tumour take in mice. $\mathrm{Br} J$ Cancer 1995;72: $1160-1164$.

13. Price JE, Polyzos A, Zhang RD, Daniels LM. Tumorigenecity and metastasis of human breast carcinoma cell lines in nude mice. Cancer Res 1990;50:717-721.

14. Leunig $M$, Yuan F, Menger MD, Boucher $Y$, Goetz AE, Messuer $K$, Jain RK. Angiogenesis microvascular architecture, microhemodynamics, and interstitial fluid pressure during early growth of human adenocarcinoma LS174T in SCID mice. Cancer Res 1992;52:6553-6560.

15. Lichtenbeld HC, Yuan F, Michel CC, Jain RK. Perfusion of single tumor microvessels: application to vascular permeability measurement. Microcirc 1996; 3:349-357. 
16. Duijvestijn AM, Kerkhove $M$, Bargatze RF, Butcher EC. Lymphoid tissue- and inflammation-specific endothelial cell differentiation defined by monoclonal antibodies. J Immunol 1987; 138:713-719.

17. Sharkey FE, Fogh J. Considerations in the use of nude mice for cancer research. Cancer Metastasis Rev 1984;3:341-360.

18. Wakasugi $H$, Koyama $K$, Gyotoku $M$, Yoshimoto $M$, Hirohashi $S$, Sugimura $T$, Terada M. Frequent development of murine T-cell lymphomas with TcR alpha/beta,$+ C D 4 / 8$ - phenotype after implantation of human inflammatory breast cancer cells in BALB/c nude mice. Jpn J Cancer Res 1995;86:1086-1096.

19. Nguyen $M$, Watanabe $\mathrm{H}$, Budson AE, Richie JP, Hayes DF, Folkman J. Elevated levels of an angiogenic peptide, basic fibroblast growth factor, in the urine of patients with a wide spectrum of cancers. I Natl Cancer Inst 1994:86:356-36I.

20. Brown LF, Berse B, Jackman RW, Tognazzi K, Guidi AJ, Dvorak HF, Senger DR, Connolly IL, Schnitt SJ. Expression of vascular permeability factor (vascular endothelial growth factor) and its receptors in breast cancer. Hum Pathol 1995; 26:86-91.

21. Relf $M$, LeJeune $S$, Scott PAE, Fox $S$, Smith $K$, Leek $R$, Moghaddam $A$, Whitehouse R, Bicknell R, Harris AL. Expression of the angiogenic factors vascular endothelial cell growth factor, acidic and basic fibroblast growth factor, tumor growth factor $\beta-1$, platelet-derived endothelial cell growth factor, placenta growth factor, and pleitrophin in human primary breast cancer and its relation to angiogenesis. Cancer Res 1997;57:963-969.

22. Hanahan D, Folkman J. Patterns and emerging mechanisms of the angiogenic switch during tumorigenesis. Cell 1996;86:353-364. 


\section{Chapter 8}

General discussion 


\section{Generall discussion}

The important role of the vasculature in tumor development has been recognized for several years now! and different models have been developed to investigate the mechanism of action of tumor angiogenesis induction and vessel formation ${ }^{2-5}$. In some models only parts of the angiogenic cascade are studied like for instance proliferation or migration of endothelial cells (EC). The aim of the study presented in this thesis was to develop an angiogenesis model which could be used for screening of antiangiogenic drugs and for the estimation of the angiogenesis capacity of tumor biopsies.

For a reliable interpretation of the use of tumor cell lines in the in vitro angiogenesis model first the in vitro characteristics of the tumor cell lines were evaluated (chapter 3 ). Because the hormone receptor status plays an important role in the growth and prognosis of breast cancer patients we have chosen three breast cancer cell lines: T47D and MCF-7, which are estrogen receptor and progesterone receptor positive, and Hs578T, which is a estrogen receptor and progesterone receptor negative cell line. Cells can be cultured as multicellular spheroids, which mimics the in vivo growth of a tumor, or as a monolayer. When spheroids have a diameter of $250 \mu \mathrm{m}$ or more, they develop a necrotic core surrounded by viable cells, a phenomenon which has also been reported in the in vivo situation ${ }^{6}$. It is suggested that necrosis and the hypoxia in the center of a tumor initiates the secretion of angiogenic factors. In a monolayer system such a phenomenon obviously does not occur.

The characteristics of the breast cancer cell lines grown as monolayers and as spheroids were compared because the growth configuration could influence the growth characteristics of the tumor cells and via these perhaps also their angiogenesis inducing capacity. The results showed that the configuration in which the cells were cultured did not influence the expression of the proliferation marker $\mathrm{Ki}-67$ or the (indirect) markers for apoptosis bcl-2 and p53. However, it was found that the growth configuration influenced the expression of UPA and the inhibitor PAI- 1 . The expression of some coagulation parameters such as TF and Factor $\mathrm{Xa}$ determined in the conditioned medium of monolayer and spheroid cultures was dependent on the growth configuration also. The Hs578T cell line showed a remarkably increased expression of the proteolytic enzymes compared to the other two cell lines. Proteolytic enzymes are important for the degradation of the extracellular matrix. The high expression of proteolytic enzymes by the Hs578T cells could explain why these cells did not form spheroids but instead invaded the collagen matrix. We can thus conclude that the growth and the secretion of different compounds as proteolytic enzymes and coagullation factors can be influenced by the configuration in which the cells are grown and/or the matrix in 
which the cells are cultured. So cell-cell interactions as well as cell-extracellular matrix interactions play a role. Both models, cells grown as spheroids and cells grown as a monolayer, are reproducible and can be used but it has to be kept in mind that the configuration of the cell culture can influence the results. Furthermore, not all cell lines do form spheroids in vitro.

The following step was the use of the tumor cell lines as stimulator in an in vitro angiogenesis assay. Briefly, we made a three dimensional semi-natural extracellular matrix of collagen on which bovine microvascular endothelial cells (BMEC) were cultured. As angiogenesis stimulator in this model tumor cell spheroids, conditioned medium from tumor cell cultures and biopsy material from breast cancer patients were used. The angiogenic stimulus could be embedded in the collagen matrix (before the EC were seeded) or added on top of the EC layer in the medium. When the stimulus was added on top of the cells, the cells were first cultured to confluence. bFGF, a known angiogenesis inducer, was used as positive control in these experiments and the amount of sprouting induced by bFGF was arbitrarily chosen as $100 \%$. All the different angiogenic stimuli were compared with each other and with bFGF in the development of a most reliable and rapid method for screening of angiogenesis inhibitors (chapter 4). It can be concluded that in vitro angiogenesis can be induced with conditioned media from some but not all tumor cell lines. The use of tumor cell spheroids incorporated in a collagen gell on which EC are seeded, can be attractive as a model system for in vitro studies because it can be postulated that it mimics the in vivo situation more adequately. A problem of this model is however, that it is very difficult to compare the amount of sprouting between different experiments due to the experimental setup, i.e. variation in spheroid size and viability. Thus in the model using spheroids the angiogenic stimulus can not be standardized and therefore only a semiquantitative observation can be made. Another problem with this system is that it is time consuming. It takes about three weeks to culture spheroids from single cells. The conditioned medium system was more attractive because conditioned medium can be prepared in two days. In addition preparation of a large batch of conditioned medium enables good reproducibility.

The use of tumor biopsies, an attractive option from the clinical point of view, was more complicated. Biopsies could not be incorporated in the matrix because all biopsies clegraded the matrix and grew out in a way that made identification of endothelial sprouting impossible, probably due to the high amounts of proteolytic enzymes secreted by the biopsy. When the biopsies were cultured in the lower well of a transwell culture dish and the EC in the upper well, the results were not consistent. We speculate that the absorption of factors from the medium to the insert/filter membrane could be responsible for this ${ }^{8}$.

From the results obtained using different angiogenesis inducing agents we 
concluded that many different factors could be used to induce angiogenesis in our model system. We have chosen to use conditioned medium from the cell line Hs578T for a rapid and reliable induction of angiogenesis for screening of possible angiogenesis inhibiting drugs. In this model, in which angiogenesis was induced by the conditioned medium from the cell line Hs578T, we were able to inhibit angiogenesis efficiently with LBS-1, an analog of angiostatin which is a known angiogenesis inhibitor. It was shown that angiogenesis was even inhibited at concentrations at which the BMEC proliferation was not inhibited. So apparently the mechanism of the angiogenesis inhibition was not only a decrease in cell proliferation but it was also dependent on other factors. For that reason the effect. of angiostatin on apoptosis induction was tested. We found that angiostatin was able to induce apoptosis in the BMEC although the effect was limited. One of the problems with angiostatin was the rather strong dose-dependent effect between the different vials of angiostatin. We speculate that the product LBS- 1 is not pure and some contaminations in the preparation were able to decrease the activity of angiostatin. Because LBS-1 is taken out of production, we are not able to verify this hypothesis. Very recently there is speculated that angiostatin will be the new therapy for cancer treatment (CNN, May 4 1998). This conclusion was based on the results obtained in mice experiments in vivo and on in vitro experiments with BMEC. However, when we tested angiostatin in vitro on tuman endothelial cells (MVEC and HUVEC) we found that the effect of angiostatin on cell proliferation and apoptosis was strongly reduced when compared to the effects on BMEC (unpublished data). So extrapolation of data from mice experiments or bovine cells to the human situation is not always possible.

Subsequently different anti-tumor drugs were evaluated in the developed in vitro angiogenesis model to determine their anti-angiogenic effect (chapter 5). The effects of the drugs suramin, docetaxel and tamoxifen on EC tube formation were compared with the effects of known anti-angiogenic therapeutics (AGM-1470, IFN- $\alpha$ and marimastat) ${ }^{10,11}$. In an attempt to unravel the mechanism of angiogenesis inhibition the proliferation and apoptosis of cells cultured in the presence of the drugs were determined also. All drugs, except AGM- 1470 and suramin, were able to inhibit in vitro angiogenesis. However, both drugs were able to inhibit the $\mathbb{E C}$ proliferation. This discrepancy may be due to the methodology used. For the proliferation and apoptosis assays the cells were cultured on a flat culture dish with only a thin coating of collagen (a two-dimensional system); thus the cells could only grow in a two-dimensional direction. The in vitro angiogenesis assay was performed on a thick collagen matrix in which the cells were able to grow into the matrix also (a three-dimensional system). Another difference between the in vitro angiogenesis assay and the proliferation and apoptosis assays is that in the proliferation and apoptosis assays the cells were not grown to a confluent layer at 
the moment of addition of the drug, whereas in the in vitro angiogenesis assay the cells first were allowed to grow confluent before the drug was added. In the in vitro angiogenesis assay the monolayer was not affected by both agents whereas the layer was affected in the two dimensional proliferation and apoptosis assays. As described in chapter 3 and by others ${ }^{12}$ the matrix material and the configuration of the matrix (two-versus three dimensional) on which the cells are cultured can influence the characteristics of the cells. Maybe this is also the case for cells cultured in the presence of suramin or AGM-1470. It could be that the thick layer of collagen protects the EC for the effects of the drugs whereas only a collagen coat (two-dimensional culture) is not able to do this. Another explanation could be that suramin and AGM-1470 are less effective on a confluent layer of cells than on a sub-confluent layer in which adhesion can play a role. The in vitro angiogenesis assay includes most of the aspects of the in vivo angiogenesis cascade whereas in the proliferation assay and the apoptosis assay only one aspect of the cascade is investigated. This difference can contribute to the difference in results between the different assays also.

It has been described that both suramin and AGM-1470 are able to inhibit angiogenesis ${ }^{13-16}$. This conclusion is partly based on results obtained from proliferation assays and as we showed above, it is not reliable to conclude from proliferation assays only if a compound is able to inhibit angiogenesis. For example LBS-1 was able to inhibit in vitro angiogenesis at a concentration at which it does not affect the EC proliferation ${ }^{17}$. The angiogenesis irhibiting capacity of suramin and AGM-1470 has also been proven in a CAM (chorioallantoic membrane)-assay. However, the CAM-assay exists of embryonic angiogenesis which differs from postnatal angiogenesis. In embryonic angiogenesis the vessel formation is independent of the presence of inflammatory mediators. The composition of the extracellular matrix in the CAM is probably distinct from the matrix in wound healing and in tumors. Perhaps in the CAM, vessel formation represents partly vasculogenesis instead of angiogenesis and in the case of vasculogenesis the new vessels are formed by differentiating $\mathrm{EC}$ while in the case of angiogenesis new capillaries are formed by sprouting from preexisting vessels. Maybe all these differences can explain why the results of our in vitro angiogenesis assay differs from those obtained by earlier investigations using the CAM-assay.

Tamoxifen is effectively used as cancer therapy but the exact mechanism of inhibition of the tumor is not known at the moment. Tamoxifen is an antiestrogen but also patients with an estrogen receptor negative status respond to this therapy. At the moment women which are at risk for breast cancer are treated with tamoxifen because it is thought that low doses of tamoxifen are able to prevent breast cancer formation. It seems that tamoxifen treatment decreases the incidence of cancer in this patient group. We think that the mechanism behind this decrease in cancer incidence is (partly) inhibition of angiogenesis. As described in chapter 5, 
tamoxifen is able to inhibit in vitro angiogenesis, but it is also able to inhibit angiogenesis of MVEC and HUVEC induced by LS174T spheroids (data not shown). If there is a small tumor present in these patients, then this tumor is not able to expand because the vessel formation is inhibited and thus the supply of oxygen and nutrients to the tumor is limited and tumors stay dormant.

In an attempt to unravel the mechanism behind the inhibition of in vitro angiogenesis by the different drugs, the drugs were tested also for their capacity to inhibit proliferation and induce apoptosis in three types of EC. The results were compared with the results of all drugs tested on three different tumor cell lines. For this purpose we used BMEC, MVEC and HUVEC as the endothelial cells, and T47D, Hs578T and LS174T as the tumor cells. It was found that the known angiogenesis inhibitors were more effective in inhibiting proliferation as well as in inducing apoptosis on EC than on tumor cells. The anti-tumor drugs affected the tumor cells more than the EC, so apparently the anti-tumor drugs are not equally cytotoxic for all cells. Differences in the inhibition of proliferation were found between human and bovine EC but also between microvascular and macrovascular cells. The latter observation is in agreement with the in vivo finding that only capillaries are able to form new vessels ${ }^{18}$. So also in vitro there are differences between microvascular and macrovascular cells. This could explain why, for example, docetaxel is able to inhibit the proliferation of the microvascular cells but not that of the HUVEC. Marimastat is an example of a drug which discriminates between bovine and human cells. Marimastat is able to inhibit the human EC but not the BMEC. These results show, not surprisingly, that the effect of drugs in a bovine model or in a model using macrovascular cells does not always predict the effects on the new vessel formation in vivo. Possibly an in vitro model in which human microvascular EC are used would be better to predict angiogenesis in vivo. One of the problems with the human microvascular cells is that it is difficult to stimulate these cells to form tubes. Until now only tube formation could be induced on a fibrin layer and not on a collagen layer. A fibrin layer is however even more sensitive for proteolytic activity than a collagen layer and for that reason even more difficult to handle in the case of tumor biopsy material. We were able to induce sprouting of MVEC on a collagen gel by the inoculation of LS174T spheroids in the gel. However due to the experimental setup, i.e. variation in spheroid size and viability, only a semiquantitatief observation was possible. In preliminary experiments we found that in this MVEC model both AGM-1470 and suramin were able to inhibit sprouting (data not shown).

Suramin is a polysulfonated naphtylurea which nowadays has proven to be an effective antineoplastic drug. One of the major problems of suramin in clinical use is the small therapeutic window between the dose which is required for an effective tumor inhibition and that leading to severe toxicity ${ }^{15,19}$. For that reason an analog of 
suramin with the same effect on tumors but with less toxicity would be very valuable. Suradista is an analog of suramin which is already tested in phase I clinical trials as angiogenesis inhibitor in advanced tumors.

In chapter 6 we describe the activity of suradista, a derivative of distamycin $A$, in comparison with the activity of suramin. Both compounds were tested on endothelial cells and tumor cells to compare the antineoplastic activity and the toxicity of suradista and suramin. The capacity of suramin and suradista to inhibit proliferation and new vessel formation as well as their capacity to induce apoptosis in those cells is determined. The results showed that both suramin and suradista were able to inhibit the proliferation of endothelial and tumor cells in a dosedependent manner. Suradista showed to be more effective on tumor cells where suramin inhibited the endothelial cells stronger. Suradista was able to induce the same antineoplastic effect as suramin but was less toxic on endothelial cells. Both suramin and suradista were less effective in inhibiting proliferation when the cells were first allowed to adhere for 24 hours before the drugs were added.

Apoptosis induction was induced by both drugs in all three tumor cell types and in MVEC. In BMEC and HUVEC apoptosis was increased but not significantly. Suradista at a concentration of $50 \mu \mathrm{g} / \mathrm{ml}$ induced the same amount of apoptosis in the tumor cells as $500 \mu \mathrm{g} / \mathrm{ml}$ suramin. At the concentration of $50 \mu \mathrm{g} / \mathrm{ml}$ suradista did not affect the endothelial cells. From the proliferation and apoptosis results we conclude that suradista can induce the same anti-neoplastic activity as suramin whereas the toxicity on normal endothelial cells is reduced.

Both compounds were tested in the in vitro angiogenesis assay also. In contrast to what will be expected from the proliferation and apoptosis results suramin and suradista did not inhibit tube formation at high concentrations. We observed that both suramin and suradista had a dual effect on tube formation. At concentrations up to $50 \mu \mathrm{g} / \mathrm{ml}$ tube formation was inhibited. However, no inhibition of tube formation could be found when more than $100 \mu \mathrm{g} / \mathrm{ml}$ suramin or suradista was added; tube formation seemed even to be induced at those concentrations. This is not a direct effect on suramin or suradista on the BMEC because when culturing the cells in the presence of suramin or suradista without the angiogenesis inducer bFGF, no sprouting could be found. Fidler found the same dual effect for $\| F N-\alpha^{24}$. Only low concentrations of IFN- $\alpha$ could be used for therapy. At a high concentration IFN-OR was not able to inhibit vessel formation too. That the effect of suramin is not linearly concentration dependent and that suramin can induce sprouting has also been reported by others?. In the in vitro angiogenesis experiments suramin and suradista induced the same effects. As described above, maybe the configuration of the culture or the matrix are responsible for the discrepancy between the results of the proliferation and apoptosis assays carried out in the two-dimensional cultures and the in vitro angiogenesis assay. The time of addition of suramin and suradista, before or after adhesion of the cells, influences 
the amount of proliferation inhibition. This supports the hypothesis that adhesion and/or the state of confluence influences the effects of both drugs.

It is known that for example leukocytes and leukocyte derived cytokines can induce vascular proliferation and angiogenesis ${ }^{20}$. Because in the in vitro system no systemic factors like cells of the immune system were present, we decided to use an in vivo model system also (chapter 7).

Screening of tissues obtained from breast surgery was performed in a dorsal skin fold chamber on the back of nude mice ${ }^{21}$. In this in vivo model the skin on the back of a mouse was clipped between a titanium frame. One side of the skin was removed in a circular opening. The remaining layer was covered by a sterile coverslip so that the vessels in this layer could be observed. Under the coverslip biopsies and/or drugs could be inoculated. In this model a comparison was made between tissues from breast reductions, hyperplastic tissue, breast cancer tissue and histologically normal tissue distant from the affected tissue in the same breast. The angiogenic inducing capacity of the biopsies was investigated. The results, expressed as vessel density index, displayed consistent differences between the malignant, non-malignant, hyperplastic and normal tissues. To investigate if the model gives reproducible values of angiogenesis induction one tumor was divided over 4 mice. The results were comparable, so the results between the different breast tissues and tumors was probably not due to biological variability in the model itself. For the malignant tissue we know that it presumable already expressed the angiogenic phenotype, because for detection of breast tumors on a mamma graph the tumor has to have a size of at least $0.5 \mathrm{~cm}$ in diameter. The differences in vessel density index between the different tumors might therefore serve as a prognostic value.

The VEGF levels secreted by the breast biopsies, measured in the conditioned medium from the biopsies, were significantly higher in cancer tissue than in normal tissue controls which is consistent with the results found by others ${ }^{22.23}$. We also found elevated levels of VEGF in non-malignant hypertrophic breast tissues. The levels of VEGF in the different tissues completely paralleled the capacity of those tissues to induce angiogenesis. This result suggests that VEGF is at least one of the factors involved in the stimulation of angiogenesis in the in vivo model.

The vessels present in the umor after 14 days were proved to be from mouseorigin which showed that there was ingrowth of new vessels in the biopsy. Those vessels were functional and sufficient to supply the human tissue with nutrients for 14 days. So this in vivo model may be a useful tool for the study of angiogenic diseases. At the moment it is not clear if it is a good predictive model because the follow-up of the patients is too short. We speculate that it will be a good model as an independent, predictive and/or therapeutic indicator.

For the clinical setting it would be very valuable to have a complete human in vitro 
angiogenesis model. Hawing in mind the fact that angiogenesis starts from capillaries in the in vivo situation we recently started the development of such a human in vitro system using MVEC obtained from foreskin. Until now it turned out to be rather difficult to induce tube formation in this model, in which MVEC are cultured on the collagen layer. At the moment we are able to induce sprouting with LS174T spheroids only. With conditioned medium, bFGF, VEGF or a combination of VEGF, bFGF and TNF- $\alpha$ we were not able to induce a clear increase of sprouting when compared to the control. So, for a screening of tumor biopsies this model is not a good option at the moment. It could be used for basic research although it is very difficult to make reliable quantifications in a model in which spheroids are used as the angiogenesis inducing agent. Another factor which has to be kept in mind is that MVEC are isolated from the foreskin and therefore have the male phenotype. It is not clear at the moment if sex steroids interfere in endothelial sprouting but maybe this can influence the results when for example biopsies of breast cancer, in which the prognosis is sex steroid dependent, are screened.

In general we can conclude that both the in vitro and the in vivo model are reliable models to study tumor angiogenesis. It is dependent on the aim of the study which model is preferred. For a rapid screening of drugs for their anti-angiogenic capacity in basic research, the in vitro assay is a good model. Of course extrapolation from the in vitro results to the in vivo situation can never be straight forward. It could be that a drug, which is inactive in our in vitro model, is able to inhibit vessel formation in vivo via an indirect pathway of activation of for example the immune system. Maybe also more than one angiogenic inducer has to be used in the in vitro assay when the drug tested for its angiogenic effect shows no inhibiting activity because in the in vivo situation different tumors will induce different compounds which subsequently activate the $\mathrm{EC}$ to form tubes. After the determination of the angiogenesis inhibiting concentration in the in vitro system, in viwo testing of the drug in the mouse model could be a logical next step in the extrapolation to the clinical situation. Also when studying the mechanism behind the inhibition of angiogenesis by a specific drug, a combination of investigations using the two dimensional and three dimensional in vitro assays and the in vivo model system can be made to determine for example the contribution of proliferation, apoptosis and proteolytic activity to the overall effect.

For a rapid screening of tumor biopsies in a clinical setting the in vitro assay is a good option. In this case the conditioned medium has to be used as angiogenic stimulator because the biopsies itself degrade the matrix. The model can also be used to test the effect of drugs on tumor induced angiogenesis. In the ideal situation for every patient an optimal angiogenesis inhibiting drug and its concentration can be determined in vitro before therapy is started in the patient. The in vitro model 
might provide a good option in this respect because determinations in the in vivo model would be much more time consuming. 


\section{References}

1. Folkman $J$. What is the evidence that tumors are angiogenesis dependent? Nat Cancer Inst 1990:82:4-6.

2. Ide $A G_{*}$ Baker $\mathrm{NH}$, Warren SL. Vascularization of the brown-pearce rabbit epithelioma transplant as seen in the transparent ear chamber. Am J Roengenol Radium Ther 1939:42:891.

3. Gimbrone MA, Cotran RS, Leapman S, Folkman J. Tumor growth and neovascularization: an experimental model using the rabbit cornea. I Nat Cancer Inst $1974 ; 52: 413-427$.

4. Montesano R, Vassalli JD, Baird A, Guillemin R, Orci L. Basic fibroblast growth factor induces angiogenesis in vitro. Proc Nat Acad Sci USA 1986;83:7297-7301.

5. Koolwijk P, Van Erck MGM, De Vree WJA, Vermeer MA, Weich HA. Hanemaijer R, Van Hinbergh VWM. Cooperative effect of TNF $\alpha$, bFGF, and VEGF on the formation of tubular structures of human microvascular endothelial cells in a fibrin matrix. Role of urokinase activity. J Cell Biol 1996;132:1177-1188.

6. Chignola R, Foroni R, Candiani C. Franceschi A, Pasti M, Stevanoni G, Ansellmi $C$, Tridente $G$, Colombatti $M$. Cytoreductive effects of anti-transferrin receptor mmunotoxins in a multicellular tumor spheroid model. Int $J$ Cancer 1994;57: 268-274.

7. Pepper MS, Vassalli J-D, Wilks JW, Schweigerer L, Orci L, Montesano R. Modulation of bovine microvascular endothelial cell proteolytic properties by imhibitors of angiogenesis. J Cell Biochem 1994;55:419-434.

8. Sieuwerts AM, Klinn JGM, Foekens JA. Assessment of the invasive potential of human gynecological tumor cell lines with the in vitro Boyden chamber assay: influences of the ability of cells to migrate through the filter membrane. Clin Exp Metastasis 1997; 15:53-62.

9. O'Reilly MS, Holmgren L, Shing Y, Chen C, Rosenthal RA, Moses M, Lane WS, Cao $Y$, Sage EH, Folkman J. Angiostatin: a novel angiogenesis inhibitor that mediates the suppression of metastases by a Lewis Lung carcinoma. Cell 1994:79: 315-328.

10. Ezekowiz RAB, Mulliken JB, Folkman J. Interferon alfa-2a therapy for life-Hreatening hemangiomas of infancy. New Engl J Med 1992;326:1456-1463.

11. Ahmed MH, Arai T, Konno H, Nahar L, Tanaka T, Izumiyama N, Takubo K. Nakamura $S$, Baba $S$. Regression of metastatic liver tumors in rats treated with angiogenes is intubitor TNP-470: occurence of apoptosis and necrosis. Jpn I Cancer Res 1997;88:977-981.

12. Haas TL, Davis SI, Madri IA. Three-dimensional type I collagen lattices induce coordinate expression of matrix metalloproteinases MTI-MMP and MMP-2 in microvascular endothelial cells. I Biol Chem 1998:273:3604-3610.

13. Maier JAM, Delia D. Thorpe PE, Gasparini G. In vitro inhibition of endothelat cell growth by the antiangiogenic drug AGM-1470 (TNP-470) and the anti-endoglin antibody TEC-11. Anti-Cancer Drugs 1997;8:238-244. 
14. Takano S, Gately S, Neville ME, Herblin WF, Gross JL, Engelhard H, Perricone M, Eidsvoog K, Brem S. Suramin, an anticancer and angiosuppressive agent, inhibits endothelial cell binding of basic fibroblast growth factor: migration, proliferation, and induction of urokinase-lype plasminogen activator. Cancen Res $1994 ; 54: 2654-2660$.

15. Morris AD, Léonce S, Guilbaud N, Tucker GC, Pérez V, Jan M, Cordi AA, Pierre A, Alassi G. Eriochrome Black T, structurally related to suramin inhibits angiogenesis and tumor growth in vivo. Anti-Cancer Drugs 1997:8:746-755.

16. Gagliardi ART, Kassack M, Kreimeyer A, Muller G, Nickel P, Collins DC. Antiangiogenic and antiproliferative activity of suramin analogues. Cancer Chemother Pharmacol 1998;41:117-124.

17. Barendsz-Janson AF, Griffioen AW, Muller AD, Van Dam-Mieras MCE, Hillen HFP. In witro tumor angiogenesis assays: plasminogen lysine binding site 1 inhibuts in vitro tumor induced angiogenesis. J Vasc Res 1998;35:109-114.

18. Furcht LT. Critical factors controlling angiogenesis:cell products, cell matrix, and growth factors. Lab Invest 1986;55:505-509.

19. Braddock PS, Hu D-E, Fan T-PD, Stratford IJ, Harris AL, Bicknell R. A structure-activity analysis of antagonism of the growth factor and angiogenic activity of basic fibroblast growth factor by suramin and related polyanions. Br I Cancer 1994;69:890-898.

20. Koch AE, Polverini PJ, Kunkel SL, Harlow LA. DiPietro LA, Elner VM, Elner SG, Strieter RM. Interleukin-8 as a macrophage-derived mediator of angiogenesis. Science $1992 \cdot 258: 1798-1801$.

21. Leunig $M$, Yuan F, Menger MD, Boucher $Y$, Goetz AE, Messner K, Jain RK. Angiogenesis microvascular architecture, microhemodynamics, and interstitial fuid pressure during early growth of human adenocarcinoma LS174T in SCID mice. Cancer Res 1992;52:6553-6560.

22. Brown LF, Berse B, Jackman RW, Tognazzi K, Guidi AJ, Dvorak HF, Senger DR, Connolly JL, Schnit SJ. Expression of vascular permeability factor (vascular endothelial growth factor) and its receptors in breast cancer. Hum Pathol 1995; 26:86-91.

23. Relf M, LeJeune $S$, Scott PAE, Fox $S$, Smith $K$, Leek $R$, Moghaddan $A$. Whitehouse $R$, Bicknell $\mathbb{R}$, Harris $A L$. Expression of the angiogenic factors vascular endothelial cell growth lactor, acidic and basic fibroblast growih factor, tumor growh factor $\beta-1$, platelet-derived endothelial cell growth factor, placenta growth factor, and pleitrophin in human primary breast cancer and its relation to angiogenesis. Cancer Res 1997;57:963-969.

24. Fidler IJ. Angiogenesis in the pathogenesis of cancer metastasis. In: Proceedings Anglogenesis and Cancer. Folkman J, Klagsbruin M, ed. Orlando. 1998. 
Samenvatting 


\section{Samenvatting}

Tumoren zijn voor hun groei afhankelijk van de nieuwvorming van bloedvaten. Uitzaaiingen van de primaire tumor zullen evenmin tot nieuwe gezwellen kumnen uitgroeien zonder aanleg van nieuwe bloedvaten. Avasculaire tumoren kunnen maximaal $\mathbb{1}$ à $2 \mathrm{~mm}^{3}$ groot worden aangezien de toevoer van voedingsstoffen en zuurstof door middel van diffusie bij verdere expansie gelimiteerd is. Het proces van vaatnieuwvorming uit reeds bestaande capillairen wordt angiogenese genoemd. Tumoren zijn in staat dit proces te activeren. Onder normale (gezonde) omstandigheden zijn zowel angiogenese remmers als stimulatoren aanwezig waarvan de verhouding in balans is. Wanneer een tumor groeit en diffusie gelimiteerd wordt ontstaat een necrotische kern. De hypothese is dat ten gevolge van de necrotische kern en de daardoor ontstane hypoxie een angiogene switch optreedt in het voordeel van de stimulatoren waardoor endotheelcellen geactiveerd worden om nieuwe vaten te vormen.

Het remmen van de angiogenese zou een goede therapie kunnen zijn voor de behandeling van tumoren. Tumoren worden gedurende behandeling met de huidige therapie vaak resistent ten gevolge van de hoge mutatie mogelijkheid van de tumoren. Mogelijk kan dit probleem ondervangen worden met een angiogenese gerichte therapie aangezien in endoheelcellen, voor zover op het moment bekend, geen drug-resistentie wordt geinduceerd. Tevens is er sprake van een grote toepasbaarheid aangezien elke tumor met dezellide therapie behandeld zou kunnen worden en men bovendien niet afhankelijk is van de slechte toegankelijkheid in de tumor.

In dit proefschrift zijn twee modellen beschreven die bruikbaar zijn voor onderzoek naar tumor geïnduceerde angiogenese. De toepasbaarheid van beide modellen voor het bestuderen van tumor geïnduceerde angiogenese en de ontwikkeling van mogelijke nieuwe therapieën is eveneens beschreven.

Voor het ontwikkelen van een predictief angiogenese model waarbij de vatuorming wordt geïnduceerd door tumor cellen is het van belang de karakteristieken van de tumor cellen te kennen om het model goed te kunnen interpreteren. In hoofdstuk 3 staan de groei karakteristieken beschreven van 3 borstkanker cellijnen. Aangezien de groei van deze tumoren in vivo onder andere bepaald wordt door de aan- of afwezigheid van de oestrogeen- en progesteron-receptor, is gekozen voor twee oestrogeen- en progesteron-receptor positieve cellijnen namelijk T47D en MCF-7 en een oestrogeen- en progesteron-receptor negatieve cellijn Hs578T.

In de meeste in vitro systemen worden de cellen als monolaag (twee dimensionaal model) gekweekt, maar in vivo groeien de cellen in een drie dimensionale omgeving als kolonies ingebed in een extracellulaire matrix. In vitro kunnen cellen ook als multicellulaire celkolonies (sferoïden) gekweekt worden, en zo'n model 
benadert de in vivo situatie beter. Hoofdstuk 3 beschrijft de invloed van configuratie (monolaag versus sferoïde) en matrix (collageen versus agarose) op de proliferatie, apoptose, expressie van stollingsfactoren en de expressie van proteolytische enzymen van de drie tumor cellijnen. Het blijkt dat configuratie en matrix geen invloed hebben op de proliferatie en apoptose van de cellen maar wel van belang zijn voor de expressie van stollings parameters en de proteolytische enzymen. Beide modellen, sferoilde kweek en monolaag kweek, kunnen gebruikt worden voor verder onderzoek, echter niet iedere cellijn kan als sferoïden gekweekt worden.

In hoofdstuk 4 wordt, in vitro, tumor geïnduceerde angiogenese beschreven. In het model zijn runder bijnierschors endotheelcellen (BMEC) gekweekt op een collageen type I matrix. Verschillende wijzen wan angiogenese stimulatie zijn getest. Er is een vergelijking gemaakt ussen de gekarakteriseerde tumor cellijnen, een darm tumor cellijn en tumor biopten van patiënten. Allereerst zijn zowel de biopten als de cellijnen ingebed in de matrix en gebruikt als angiogenese stimulus. Daarnaast zijn experimenten uitgevoerd waarbij aan het kweek medium van de endotheelcellen een geconditioneerd medium, verkregen van de cellijnen en biopten, is toegevoegd. De angiogene capaciteit van de verschillende stimuli is vergeleken met het effect geïnduceerd door de bekende angiogenese stimulator basic fibroblast growth factor (bFGF). Van de geteste cellijnen blijkt het geconditioneerde medium van de cellijn Hs578T de beste stimulator te zijn. Het gebruik van tumor biopten is beperkt tot het gebruik van geconditioneerd medium aangezien de biopten zelf een te hoge proteolytische activiteit hebben waardoor de matrix waarin ze gekweekt worden volledig wordt gedegradeerd en het niet mogelijk is de gevormde spruiting te kwantificeren.

De bruikbaarheid van het model waarbij spruitvorming wordt geïnduceerd door het geconditioneerde medium van de cellijn Hs578T is aangetoond met behulp van de bekende angiogenese remmer LBS-1 (angiostatine). Het blijkt dat angiostatine in staat is de spruitvorming wolledig te blokkeren, zelfs bij concentraties waarmee angiostatine niet in staat is om de endotheelcel proliferatie te remmen.

In hoofdstuk 5 staan de resultaten beschreven van de cytostatica docetaxel, suranine en tamoxifen op vaatnieuwvorming welke is vergeleken met het effect van de angiogenese remmers interferon- $\alpha$, AGM-1470 en marimastat. Op suramine en AGM-1470 na zijn alle middelen in staat in vitro angiogenese te remmen. Docetaxel is zelfs in staat de vaatworning volledig te blokkeren.

Mogelijke mechanismen van angiogenese remming zijn de remming van de cel proliferatie en de inductie van cel apoptose. Om die remmingseffecten te meten werden verschillende soorten cellen gebruikt: humane microvasculaire- (MVEC), macrovasculaire- (HUVEC) en runder bijnierschors endotheelcellen (BMEC). De 
effecten op de endotheelcellen zijn vergeleken met de effecten op de tumnor cellijnen T47D, Hs578T en LSI74T (darn tumor) om zo de mogelijke cytotoxiciteit te bepalen. Uit de proliferatie en apoptose experimenten blijkt dat de bekende angiogenese remmers een groter effect hebben op de endotheelcellen terwijl cytostatica de tumor cellen sterker beïnloeden. De renming van de spruiting blijkt deels veroorzaakt te worden door de toename in apoptose in de endotheelcellen.

Het cytostaticum suramine wordt bij de behandeling van verschillende soorten tumoren toegepast. Helaas liggen de effectieve behandelings- en de toxische dosis dicht bij elkaar. Een middel met dezelfde anti-neoplastische activiteit maar een lagere toxiciteit zou de voorkeur verdienen. Onderzocht is of suradista, een analoog van suramine, aan deze voorwaarden voldoet. Voor beide middelen is het effect op proliferatic en apoptose van endotheelcellen en tumorcellen bestudeerd, alsmede het effect op in vitro angiogenese (hoofdstuk 6). Uit het onderzoek blijkt dat suradista inderdlaad dezelfde anti-neoplastische activiteit heeft als suramine maar een verlaagde toxiciteit induceert in vergelijking met suramine. Het effect op de in vitro angiogenese is voor beide cytostatica vergelijkbaar.

Hoofdstuk 7 beschrijft een in vivo angiogenese model. In dit model is een 'kamer" gemaakt op de rug van een muis. De huid op de rug van een immuun deficiënte muis is geklemd tussen een titanium frame, één zijde van de huid is weg geprepareerd zodat tegen de binnenzijde van de achtergebleven huid gekeken wordt. De kamer wordt vervolgens gesloten met een dekglaasje zodat de vaatnieuwvorming vervolgd kan worden zonder dat de kamer geopend hoeft te worden. Op deze wijze kan de angiogenese inducerende capaciteit worden bestudeerd. In deze kamer zijn nu verschillende stukjes humaan borstweefsel getransplanteerd. De volgende soorten zijn vergeleken: gezond weefsel verkregen bij borst reducties, weefsel met een hyperplasie, maligne tumor weefsel en van dezelfde patiënt histologisch normaal weefsel een paar centimeter verwijderd van de turnor. Deze weefsels blijken een andere angiogenese inducerende capaciteit te hebben waarbij het hyperplastische en tumor weefsel de grootste en het controle weefsel de laagste angiogenese inducerende capaciteit hebben. Ook in de groep met maligne weefsel zijn verschillen warmeembaar die niet veroorzaakt worden door de variabiliteit van het bio-assay model. Dit model zou dus ook voor screening van biopten gebruikt kunnen worden en voor het evalueren van mogelijke nieuwe antitumor middelen.

Samengevat kan worden opgemerkt dat zowel het in vitro als het in vivo model toepasbaar zijn woor het bepalen van tumor geïnduceerde angiogenese en de ontwikkeling van mogelijke nieuwe therapieën. 


\section{Dankwoord}




\section{Dankwoord}

Zoals iedereen weet doe je een promotie onderzoek niet alleen. Een proefschrift komt tot stand door de bijdrage en steun van vele personen. Langs deze weg will ik iedereen die op enigerlei wijze heeft bijgedragen aan de totstandkoming van dit proefschrift hartelijk danken voor zijn/haar steun. Een aantal mensen wil ik in het bijzonder noemen.

Allereerst wil ik mijn drie begeleiders, Prof dr HFP Hillen, Prof dr MCE van Dam-Mieras en dr AW Griffioen, bedanken voor de bijdrage die ieder op haar/zijn eigen terrein heeft gegeven bij het schrijven van de artikelen en de totstandkoming van dit proefschrift. Ook alle studenten en artsen die de afgelopen jaren het lab 'onveilig' hebben gemaakt wil ik hierbij bedanken voor hun wetenschappelijke inbreng maar ook vooral voor de gezellige niet-wetenschappelijke avonden. Jos voor jou nog even extra aandacht omdat jij na het scannen van de vele foto's toch nog mijn paranimf wilde zijn. Daarnaast natuurlijk alle collega's van onze eigen werkgroep als wel van de immunologie, pathologie en endocrinologie bedankt voor jullie hulp. Een speciaal woord van dank wil ik richten tot Elly. Jij hebt met veel enthousiasme gewerkt aan het verkrijgen van bijna alle suramine/suradista resultaten. Daarnaast heb ik je ook nog bereid gevonden om mijn paranimf te zijn, dank je wel. Puck, bedankt voor het isoleren van de MVECs uit de voorhuidjes verkregen uit heel Limburg. Tiny, jij bedankt voor je hulp bij het maken van de lay out en het druk klaar maken van dit proefschrift. Ingrid, jij vooral bedankt voor je altijd luisterend oor, de wetenschappelijke discussies, gezellige avonden en dat jij op zo'n korte afstand voor mij wilde promoveren zodat ik de kunst een beetje kon afkijken.

Tot slot wil ik natuurlijk het 'thuisfront' bedanken. Diederick, pap en mam, dankzij jullie altijd aanwezige steun ben ik aan dit promotie onderzoek begonnen en heb ik het in 4 jaar weten af te ronden; dank je wel. 


\section{Curriculum Vitae}




\section{Curriculum Vitae}

De auteur van dit proefschrift werd op 15 januari 1970 te Sittard geboren. Het VWO-diploma werd behaald in 1988 aan de Rooms-Katholieke Scholengemeenschap Serviam te Sittard. In september van dat jaar werd begonnen met de studie Gezondheids Wetenschappen (later Bionedische Wetenschappen genoemd) aan de Rijksuniversiteit Leiden. Tijdens haar afstudeerstage deed zij onderzoek naar de rol van plasminogeen activatoren bij tumor cel migratie bij TNO-PG te Leiden onder leiding van dr PHA Quax en dr JH Verheijen. In april 1994 werd het doctoraal van de studie behaald.

Vanaf 1 juli 1994 was de auteur werkzaam aan de Universiteit Maastricht als assistent in opleiding (AIO) binnen de onderzoeksgroep Groei en Ontwikkeling. Het onderzoek werd uitgevoerd bij de afdeling Interne Geneeskunde, werkgroep Hematologie/Oncologie onder leiding van Prof dr HFP Hillen, Prof dr MCE van Dam-Mieras en dr AW Griffioen. De resultaten van dit promotie onderzoek staan in deze dissertatie beschreven. Sinds september 1998 is zij werkzaam als post-doc bij de afdeling neurochirurgie/kinderoncologie van de Erasmus Universiteit te Rotterdam.

\section{List of publications}

AF Barendsz-Janson, AD Muller, HHC Lichtenbeld, MCE van Dam-Mieras, HFP Hillen. Cellular arrangement of human breast cancer cell lines determines hemostatic parameters. Tumor Biol 1998; 19(2): 104-112.

AF Barendsz-Janson, AW Griffioen, AD Muller, MCE van Dam-Mieras, HFP Hillen. In vitro tumor angiogenesis assays: plasminogen lysine binding site 1 inhibits in vitro tumor induced angiogenesis. J Vasc Res 1998;35(2): 109-114.

HC Lichtenbeld, AF Barendsz-Janson, H van Essen, H Struijker Boudier, AW Griffioen, HFP Hillen. Angiogenic potential of malignant and non-malignant human breast tissues in an in vivo angiogenesis model. Int J Cancer 1998;77:455-459.

AW Griffioen, AF Barendsz-Janson, KH Mayo, HFP Hillen. Angiogenesis, a targel for tumor therapy. I Lab Clin Med; in press

AF Barendsz-Janson, EAH Toebes, AW Griffioen, MCE van Dam-Mieras, HFP Hillen. In vitro effects of anti-tumor drugs on angiogenesis. Submitted 
AF Barendsz-Janson, EAH Toebes, HFP Hillen, MCE van Dam-Mieras, AW Griffioen. Apoptosis induction and anti-proliferative effects of suramin and its analog suradista. Submitted

AW Griffioen, AF Barendsz-Janson, HFP Hillen. Tamoxifen inhibits human angiogenesis. Submitted

AW Griffioen, CA Damen, KH Mayo, AF Barendsz-Janson, S Martinotti, GH Bliham, G Groenewegen. Angiogenesis inhibitors overcome tumor induced endothelial cell anergy. Submitted.

A. Barendsz-Janson, AD Muller, HHC Lichtenbeld, MCE van Dam-Mieras, HFP Hillen. Growth of human breast cancer cell lines in matrices: validation of an in vitro screening model. In: Thrombosis, atherosclerosis and inflammation. Editor: JW ten Cate 1997 (abstract)

AF Barendsz-Janson, EAH Toebes, HFP Hillen, MCE wan Dam-Mieras, AW Griffioen. Anti-angiogenic effects of tumor-drugs. Annals Oncol 1998:9(2):78 (abstract)

AF Barendsz-Janson, EAH Toebes, HFP Hillen, MCE van Dam-Mieras, AW Griffioen. Anti-angiogenic effects of anti-tumor drugs by induction of apoptosis. Endothelium, in press (abstract)

HC Lichtenbeld, AF Barendsz-Janson, AW Griffioen, HFP Hillen. Angiogenic potential of malignant and non-malignant human breast tissues in the dorsal skin fold chamber in nude mice. 24-28 jan. 1998 Orlando, Special AACR conference (abstract).

AF Barendsz-Janson, AW Griffioen, AD Muller, MCE van Dam-Mieras, HFP Hillen In witro tumor angiogenesis assays: plasminogen lysime binding site 1 and docetaxel inhibit in vitro tumor induced angiogenesis. Keystone meeting: Angiogenesis and vascular remodelling: Steamboat Springs, Co, USA, 27-3 t/m 3-4-'98 (abstract). 